Universidade de São Paulo

Escola de Comunicações e Artes

Departamento de Música

CLARISSA DA COSTA CABRAL

\title{
Os Lieder de Clara Schumann
}


CLARISSA DA COSTA CABRAL

\title{
Os Lieder de Clara Schumann
}

\author{
Versão corrigida
}

Dissertação de Mestrado apresentada ao Departamento de Música da Escola de Comunicações e Artes da Universidade de São Paulo, como exigência parcial para a obtenção do título de Mestre em Artes.

Área de Pesquisa: Processos de Criação Musical

Orientador: Prof. Dr. Amilcar Zani Netto

São Paulo 
Nome: Clarissa da Costa Cabral

Título: Os Lieder de Clara Schumann
Dissertação de Mestrado apresentada ao Departamento de Música da Escola de Comunicações e Artes da Universidade de São Paulo, como exigência parcial para a obtenção do título de Mestre em Artes.

Aprovada em:

Banca Examinadora:

Prof. Dr.

Instituição

Assinatura

Prof. Dr.

Instituição

Assinatura

Prof. Dr.

Instituição Assinatura 
Aos meus professores que sempre me fizeram reconhecer personagens que obtiveram êxito traçanda caminhos carretos. direcionados pelas esforcos intelectuais.

À minha familia que sempre me ensinou e promouen a suparte necessária para que en busque esses ideais. 


\section{AGRADECIMENTOS}

Ao Amilcar e à Heloísa, pela dedicação e carinho em todos esses anos de amizade.

Ao meu irmão André, por me ajudar e me compreender tão bem.

Aos meus pais, pelo amor.

À minha família, pelo apoio incondicional.

À minha querida amiga Alexandra Fernandes, pela ajuda nos momentos difíceis.

À amiga Eliana Monteiro pela parceria musical.

Ao amigo Fernando Tomimura, com quem pude compartilhar todas as etapas deste trabalho.

Aos amigos Regina Migliore, Rafael Luz, Pedro Diniz, Adriano Pinheiro, que me ajudaram a conseguir materiais necessários para o desenvolvimento deste trabalho. À amiga Solange Ferreira, pelo carinho. 
"A interpretaçãa musical nãa é alsoluta. Se ela fasse absoluta, a intérprete nãa existiria. Uma única grawaçãa paria fim à interpretaçãa.

A música é um abjeto presente que se madifica em todo momento de acorda cam a personalidade e a sensibilidade de cada pessaa. Issa justifica as inúmeras grawaçöes da mesma partitura. (...) Em música ninguém é dona da verdade. É clara que nãa se pade admitir absurdas musicais, mas tuda que está fundamentado deve ser respeitado".

Walter Bianchi "Interpretação Musical baseada na Lei do Universo" 
CABRAL, C.C. Os Lieder de Clara Schumann. 2011. 152f. Dissertação (Mestrado)

- Escola de Comunicações e Artes, Universidade de São Paulo, São Paulo, 2011.

\section{RESUMO}

Este trabalho tem como objetivo apresentar um modelo de análise musical que fundamenta uma possibilidade interpretativa dos Lieder - gênero musical resultante da fusão das linguagens poética e musical - de Clara Schumann, pianista e compositora alemã do século XIX que teve papel relevante no cenário musical de sua época, realizando a primeira audição e divulgação da obra de muitos dos seus contemporâneos, especialmente de seu marido, Robert Schumann. As análises evidenciam o elevado nível artístico dessas composições, as quais abordam questões relacionadas ao período romântico em um contexto musical extremamente elaborado. A gravação que acompanha esta dissertação pretende oferecer um esboço de possibilidades para a interpretação dos Lieder analisados.

Palavras-chave: Clara Schumann; Lieder, análise musical; interpretação; século XIX. 
CABRAL, C.C. Os Lieder de Clara Schumann. 2011. 152 f. Thesis (MA)

- Escola de Comunicações e Artes, Universidade de São Paulo, São Paulo, 2011.

\begin{abstract}
This paper introduces a musical analysis model which underlies an interpretative possibility of the Lieder - musical form resulting from the fusion of poetry and music by Clara Schumann, German pianist and composer of the $19^{\text {th }}$ Century. Her role in the musical scenario was quite relevant, since she held first auditions and thus disseminated the works of many contemporary composers, specially her husband, Robert Schumann. The analysis corroborates the high artistic level of these compositions, which bring into contact with issues related to the romantic period in a highly elaborated musical work. The included CD offers interpretation possibilities for the analyzed Lieder.
\end{abstract}

Keywords: Clara Schumann; Lieder; Musical analysis; Interpretation; $19^{\text {th }}$ Century. 


\section{SUMÁRIO}

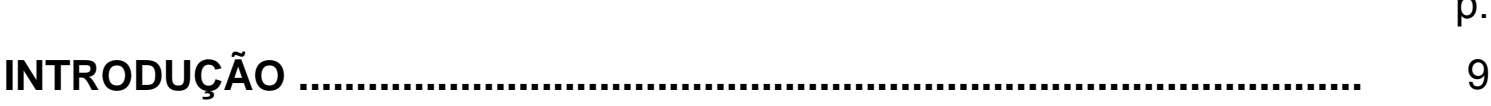

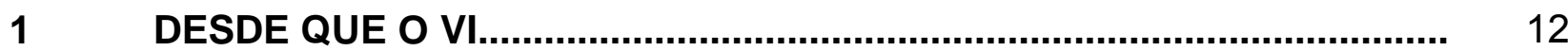

1.1 CLARA SCHUMANN: INTÉRPRETE E COMPOSITORA DE

LIEDER

1.2 OS ANOS DO CASAMENTO COM SCHUMANN ................................... 21

1.2.1 Em Leipizig............................................................................... 21

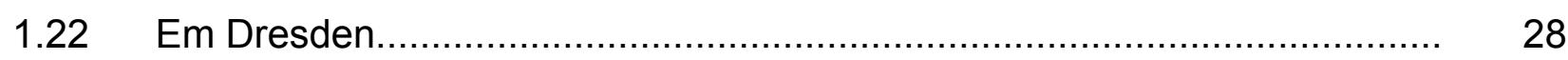

1.2.3 Em Düsseldorf............................................................................... 31

$1.3 \quad$ LISTA CRONOLÓGICA DOS LIEDER DE CLARA................................. 34

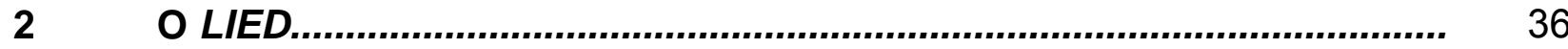

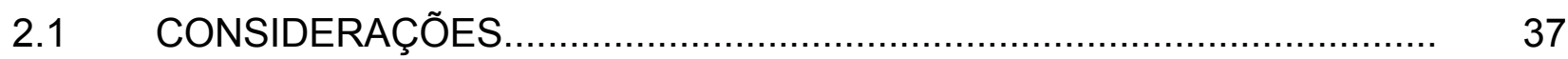

2.2 O LIED NO SÉCULO XVIII.................................................................. 39

2.3 O LIED ROMÂNTICO: PANORAMA POÉTICO........................................... 46

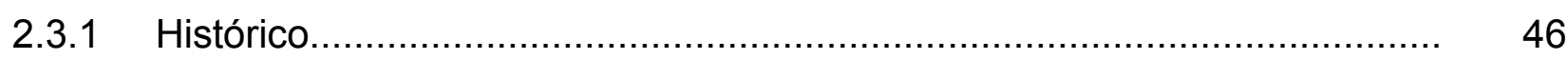

2.3.2 Características do gênero poético.......................................................... 52

$3 \quad$ PROPOSTA DE ANÁLISE............................................................. 58

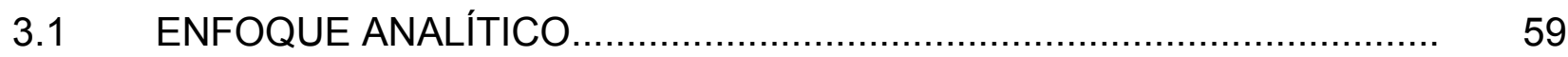

3.2 ANÁLISE POÉTICA E FORMA MUSICAL............................................ 60

3.3 LINHA MELÓDICA VOCAL................................................................. 65

3.4 ACOMPANHAMENTO PIANÍSTICO ........................................................ 69

3.5 DEFINIÇÕES SUBJETIVAS .................................................................. 71

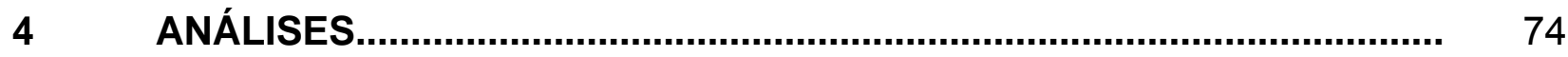

$4.1 \quad$ DER ABENDSTERN.............................................................. $\quad 75$

4.1.1 Análise poética e forma musical............................................................. 75

4.1.2 Linha melódica vocal..................................................................... 76

4.1.3 Acompanhamento pianístico ........................................................... 77

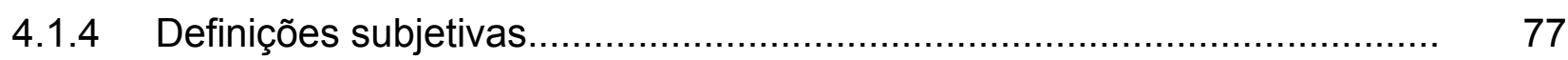

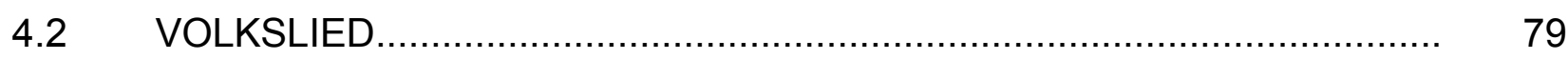

4.2.1 Análise poética e forma musical......................................................... 79 
4.2.2 Linha melódica vocal........................................................................ 81

4.2.3 Acompanhamento pianístico.................................................................. 82

4.2.4 Definições subjetivas.............................................................................. 82

4.3 DIE GUTE NACHT, DIE ICH DIR SAGE .............................. 86

4.3.1 Análise poética e forma musical.......................................................... 86

4.3.2 Linha melódica vocal...................................................................... 88

4.3.3 Acompanhamento pianístico............................................................... 88

4.3.4 Definições subjetivas...................................................................... 89

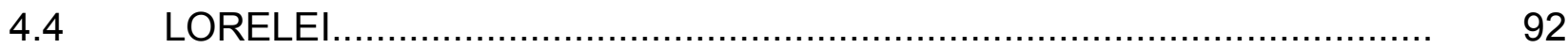

4.4.1 Análise poética e forma musical....................................................... 92

4.4.2 Linha melódica vocal........................................................................ 94

4.4.3 Acompanhamento pianístico............................................................. 95

4.4.4 Definições subjetivas............................................................................... 95

4.5 O WEH SCHEIDENS, DAS ER TAT ................................................... 102

4.5.1 Análise poética e forma musical....................................................... 102

4.5.2 Linha melódica vocal......................................................................... 103

4.5.3 Acompanhamento pianístico.............................................................. 104

4.5.4 Definições subjetivas....................................................................... 105

4.6 BEIM ABSCHIED.................................................................. 108

4.6.1 Análise poética e forma musical........................................................ 108

4.6.2 Linha melódica vocal.................................................................. 110

4.6.3 Acompanhamento pianístico......................................................... 111

4.6.4 Definições subjetivas...................................................................... 112

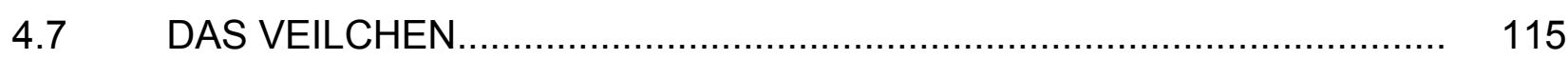

4.7.1 Análise poética e forma musical.......................................................... 115

4.7.2 Linha melódica vocal....................................................................... 117

4.7.3 Acompanhamento pianístico............................................................ 118

4.7.4 Definições subjetivas........................................................................... 118

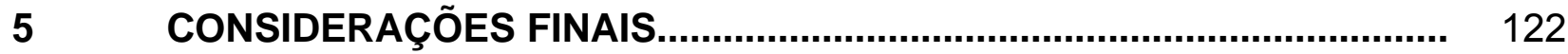

REFERÊNCIAS.............................................................................. 127

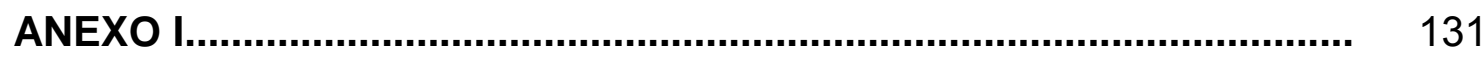


INTRODUÇÃO

Este trabalho apresenta um estudo sobre os Lieder de Clara Schumann. Seu objetivo, baseado em pesquisas sobre o gênero e o contexto histórico-cultural, é produzir um conjunto de análises que possam orientar e estimular outros pesquisadores, intérpretes, musicistas, que estejam interessados em explorar a obra desta compositora.

Clara Schumann foi considerada a maior pianista de sua época. Além de concertista cuja carreira era reconhecida internacionalmente, era também compositora, esposa e mãe de oito filhos com o compositor Robert Schumann. Apresentando-se nas principais salas de concerto europeias conquistou, em vida, projeção enquanto virtuose, teve suas composições editadas, obteve independência financeira para sustentar-se e aos seus filhos, mesmo após a morte de Robert.

Ao estudarmos o universo de Clara Schumann é necessário tangenciar o papel que a mulher ocupava na sociedade no século XIX, a qual sem dúvida impunha regras rígidas e limitava a atuação profissional feminina. No decorrer de nosso estudo apresentamos algumas referências à posição social da mulher nesta época, bem como a fatores que foram determinantes nas escolhas de Clara, principalmente no que diz respeito à composição. Entretanto, a questão feminina não será o objeto central desta dissertação. Optamos dirigir o trabalho através de um estudo que se detém na qualidade e importância da obra desta compositora, da mesma maneira que se estuda a obra de qualquer outro compositor. Suas criações musicais são o resultado de um trabalho pensado com acuidade, dotadas de elaborado processo criativo e teor musical, que sem dúvida merecem ser estudadas com a devida atenção e respeito.

Para amparar a nossa análise, recorremos a informações relativas à sua biografia e ao contexto histórico em que foram compostas as obras. De modo a viabilizar nosso trabalho, decidimos analisar somente os Lieder que tem a maior carência de informações, e que somam um total de sete peças, incompreensivelmente editadas apenas em 1992: Der Abendstern; Volkslied; Die gute Nacht, die ich dir sage; Lorelei; Oh weh des Scheidens, das er tat; Beim Abschied e Das Veilchen. Sobre estas obras, e em defesa de sua publicação, Nancy Reich afirma: 
Os Lieder que não foram publicados durante sua vida estão no mesmo nível dos publicados, e incluem alguns de seus melhores trabalhos. Não se pode entender ou saber por que a edição desse material demorou 140 anos (REICH, 2001, p. 239)

A dissertação está dividida em quatro capítulos. O primeiro capítulo, Desde que o vi... aborda dados de sua biografia, pois estamos cientes de que seria impossível estudar a obra dessa compositora sem dedicar atenção a fatos determinantes que afetaram a sua vida, e, consequentemente, seu trabalho profissional e criativo. Neste capítulo situamos o leitor no universo sociocultural do qual Clara Schumann fazia parte. Optamos por um recorte aprofundado do período específico em que Clara esteve casada com Robert, uma vez que foi a época em que compôs a maioria dos seus Lieder. Para este estudo nos baseamos em informações provindas de fontes primárias, cartas e fragmentos do diário do casal Schumann ${ }^{1}$.

No segundo capítulo, $\underline{\mathrm{O} \text { Lied, }}$ apresentamos um histórico desse gênero, concentrando nele a atenção de seu desenvolvimento desde os seus primórdios, no século XVIII, tendo em vista que muitas das características deste gênero no período denominado Romantismo provém de uma reação aos períodos anteriores, o lluminismo e o Classicismo. Ao pensar em Lied Romântico e no seu desenvolvimento é impossível não pensar em compositores como Franz Schubert e Robert Schumann. Mesmo sem abordar diretamente a obra destes compositores uma vez que novamente seria necessário outro desvio do foco deste trabalho - ela sempre ecoa no universo musical de Clara.

No terceiro capítulo, Proposta de Análise, descrevemos o modelo analítico aplicado às peças que são o objeto de estudo desta dissertação. Para a definição deste modelo se fez necessária uma pesquisa bibliográfica sobre o gênero Lied e nesse processo localizamos diferentes autores que se dedicaram ao estudo do Lied Romântico. O foco principal desta diversidade bibliográfica detém-se no aspecto histórico. Uma grande parcela deste material aborda o estudo de uma peça específica, não propondo uma metodologia de análise que possa ser utilizada em

\footnotetext{
1 Somos conscientes da necessidade de um estudo cauteloso deste material. Estes documentos, frutos de um momento determinado, refletem o pensamento ou o desejo dos autores, produzidos no calor da hora. Muitas das ideias podem ser contraditórias e mesmo inverossímeis.
} 
outras obras. Um dos estudos que inspirou muitas de nossas conclusões foi Poetry into Song, livro de Deborah Stein \& Robert Spillman. Este é um trabalho direcionado ao intérprete, tanto vocal como instrumental, que conduz à reflexão sobre as peculiaridades do gênero que devem ser levadas em conta em uma perfomance ideal. Esse material foi a base para a realização deste capítulo, que tem por objetivo elencar e elucidar os parâmetros a serem analisados. Com o intuito de normatizar a nomenclatura analítica musical, evitando dúvidas ou confusões, seguiremos os conceitos adotados por Arnold Schoenberg em seu livro Fundamentos da Composição Musical, na tradução de Eduardo Seincman.

No quarto e último capítulo, Análises, apresentamos as análises realizadas com base nos conceitos expostos no capítulo anterior. Estas análises fundamentaram o trabalho de interpretação que faz parte da performance dos Lieder de Clara Schumann, também registrados na gravação que acompanha esta dissertação.

Como tivemos dificuldades em conseguir edições dos Lieder de Clara em tonalidades próprias para vozes médias, julgamos pertinente apresentar em anexo (ANEXO I) as partituras utilizadas para a gravação do CD (APÊNDICE I) que acompanha esta dissertação. Acreditamos que este trabalho contribuirá para que um número maior de músicos se dedique ao estudo deste repertório. 
1 DESDE QUE O VI... 
Eu sentia que passuia talento criativa, mas abandonei essa ideia. Uma mulher nãa deve ter a deseja de campar - nãa existiu menhuma mulher compasitora, par que eu deveria ser a primeira? Ista deve ser presunçãa minha, resultado de um equívaca que meu pai implantan em mim durante minha infância.

Clara Schumann 


\subsection{CLARA SCHUMANN: INTÉRPRETE E COMPOSITORA DE LIEDER}

No século $\mathrm{XIX}$ as mulheres deveriam manter um comportamento modesto, cultivar a humildade, e evitar atividades criativas. Esses fatores não afetaram as ambições de Clara como concertista, mas traziam-Ihe desconforto em relação à atividade composicional. Mesmo alternando momentos de dúvida em relação às suas habilidades composicionais, Clara persistiu e compôs durante todo o período em que seu marido viveu².

Clara Schumann recebeu de Friedrich Wieck ${ }^{3}$ uma sólida formação musical que incluía aulas de canto, violino, instrução em orquestração e a presença regular nos eventos musicais da cidade de Leipzig, entre outras. Wieck sentia-se dono de Clara, chegando ao ponto de escrever no diário de sua filha em primeira pessoa, como se fosse ela. Estas atitudes levantaram suspeitas de que os Lieder de Clara teriam sido compostos por seu pai, do mesmo modo que ele escrevia em seu diário. Mas, é certo que ele não é o responsável pela composição dessas peças. Os trabalhos composicionais de Wieck não têm o mesmo encanto ou a habilidade que os de sua filha. Sem dúvida, essas composições são o resultado da sólida educação musical propiciada por seu pai.

O pai de Clara conhecia os anseios do público de concerto da primeira metade do século XIX. Este público desejava e admirava ver um pianista virtuoso interpretar as suas próprias composições, além das obras de outros compositores. Em função disto, o pai e professor de Clara a estimulou, desde a infância, a interpretar - tocando ou cantando - Lieder de sua autoria e também suas composições para piano solo. Portanto, a maioria de suas composições de juventude era escrita para ser tocada em seus recitais: uma improvisação ou um trabalho original estavam sempre presentes em seus concertos entre 1830 e 1838.

Infelizmente alguns de seus Lieder de juventude desapareceram, e são conhecidos apenas por menções no diário, na correspondência ou pelos programas de concerto.

\footnotetext{
${ }^{2}$ Uma das razões para ela ter parado de compor após a morte de seu marido é o grande número de responsabilidades como mãe e musicista.

${ }^{3}$ Pai e professor de Clara, conhecido principalmente pelo seu trabalho como professor de piano e de música. Fabricava instrumentos, recebia músicos, alugava pianos e partituras e organizava concertos.
} 
Esse estímulo à composição representava uma postura avançada para a época. Naquele momento, editar ou publicar obras compostas por mulheres era inusitado. Como prova do pensamento desse período, podemos citar as palavras do músico Hans Von Büllow (1830-96): “Não haverá jamais uma mulher compositora. (...) Eu não creio numa versão feminina do criador. Acima de tudo, eu detesto isto que representa a emancipação feminina" (BÜLLOW apud SILVA, 2011, p.25).

Aos 14 anos de idade, muitas características do novo romantismo podiam ser ouvidas nas composições de Clara: a técnica que exigia bravura; a ária lírica - em seções intermediárias; a forma miniatura com associações extramusicais; a perda da estrutura regular da frase; os experimentos com ritmo e métrica, o uso de ritmos como a polonaise e a mazurka.

Entre as influências que recebeu, não é surpreendente que Robert Schumann ocupe um dos mais importantes lugares. Tanto nos Lieder quanto nos trabalhos instrumentais, eles desenvolveram uma cooperação e intercâmbio de ideias musicais. Desde 1832, Schumann era dependente da jovem de 12 anos para tocar suas peças, em função do problema em sua mão que o impedia de tocar. A partir de 1833 a correspondência entre eles é repleta de jogos musicais, enigmas e mensagens secretas que se referiam às músicas que ambos compunham.

No início de 1839 eles trocavam informações sobre textos que poderiam servir para a composição de Lieder. Clara e Robert liam poesias atentos às possibilidades de uma nova composição, e levavam esses poemas ao conhecimento um do outro. Sabe-se que Robert pedia a Clara que encontrasse material para que ele compusesse Lieder. Em maio de 1840, no auge do período dedicado à composição desse gênero, ele escreve a Clara: "Escreva para mim com frequência. E traga-me poemas para serem musicados" (SCHUMANN, R. apud REICH, 2001, p.214).

Um livro no arquivo de Zwickau ${ }^{4}$ intitulado: Abschriften Von Gedichten zur Composition (Cópias de poemas para a composição) inclui poemas escritos pelo casal. É sabido que Clara estava envolvida nesta atividade antes mesmo do seu casamento (há uma seção intitulada: Coletadas por Robert e Clara desde 1839). Dos 169 poemas do livro, 106 foram escritos por Clara. Muitos dos textos que ela

\footnotetext{
${ }^{4}$ Uma série notória de artigos acadêmicos, contendo documentos provenientes dos arquivos da Robert-Schumann-Haus, em Zwickau (cidade natal de Schumann, localizada na Saxônia), passou a ser publicada em 1971 (REICH, 2001, in prefácio).
} 
utilizou foram copiados por Robert, e muitos dos que ele utilizou foram copiados por ela.

A motivação para a composição dos Lieder, aos quais temos acesso hoje, está intimamente relacionada a Robert - pelo fato de os dois se dedicarem à produção desse gênero em um mesmo período. A composição de muitos deles surgia como presentes que trocavam em datas como o Natal ou aniversários.

Clara e Robert encorajavam, criticavam e dedicavam trabalhos importantes um para o outro. Robert continuamente incentivava sua esposa a compor e a catalogar seus manuscritos. Ele insistia que Clara devia tratar seus trabalhos com cuidado e respeito, queria que ela fizesse e tivesse cópias de seus Lieder. A letra dele é encontrada em algumas capas de seus trabalhos, dando sugestões relativas ao tempo e ao nome das peças.

Antes de apresentarmos características dos Lieder de Clara, é fundamental falar a respeito do seu principal incentivador, Robert Schumann. Esta é a razão que nos leva a fazer, nos próximos parágrafos, uma rápida explanação de peculiaridades da obra deste compositor.

Schumann tinha um temperamento peculiar: seus ânimos oscilavam constantemente, momentos de euforia alternavam-se com outros de profunda depressão, oscilação, muitas vezes, sem motivo aparente. Esta característica emocional aparece refletida em toda a sua obra na presença dos duplos Florestan e Eusebius $^{5}$.

A obra Shumanniana pode ser dividida em fases com produção musical definida e para o nosso trabalho nos deteremos na segunda. A primeira compreende a década de 1830 a 1840, e é marcada pela exclusividade da produção pianística. A segunda compreende a produção camerística. No dia primeiro de fevereiro de 1840 , data em que o próprio compositor afirma em seu diário, começa oficialmente o que Schumann definiu como: Liederjahr (ano dos Lieder).

Os Lieder de Schumann, como todo o restante de sua obra, tem como característica vertebral que os une, uma espécie de exaltação dos sentimentos destinados à sua amada Clara, como podemos observar na escolha da poesia, no aproveitamento de temas, sendo esta uma característica não tão frequente nos

5 Para informações detalhadas sobre a influência dos duplos na obra de Schumann, consultar o substancioso estudo - ZANI NETTO, A. Florestan e Eusebius: por que? 1988. 194 f. São Paulo: Tese (Doutorado em Artes) - Escola de Comunicações e Artes, Universidade de São Paulo, São Paulo, 1988. 
Lieder. Durante a primavera e o verão do ano de seu casamento, celebrado no dia 12 de setembro de 1840, Schumann compôs alguns dos seus melhores ciclos, que fariam parte do presente de casamento para Clara, e entre eles estavam: Liederkreis op.24 e Dichterliebe com poemas de Heine; Liederkreis op.39 com poemas de Eichendorff; Frauenliebe und Leben com poemas de von Chamisso, e o ciclo Myrthen op. 25 com poemas de Heine.

O Lied foi, possivelmente, o gênero composicional mais comercial dentre as obras de Schumann ${ }^{6}$. Nesse período a intenção de Schumann era conquistar uma estabilidade financeira, uma vez que a ausência de condições financeiras para sustentar esposa e filhos era um dos principais argumentos utilizados por Wieck para impedir seu casamento com Clara $^{7}$.

É no Lied que Schumann encontra um meio ideal de cumprir a sua longa busca de sintetizar música e poesia. Para Schumann o Lied não é apenas uma melodia apoiada por um acessório decorativo, mas a união de voz e piano como parceiros iguais em um discurso compartilhado. O seu propósito era recriar a essência do poema, e para isso era necessário compreender os mais significativos detalhes da poesia, para poder representá-los através de um conteúdo musical profundo.

Durante o outono e todo o inverno que se seguiram ao casamento a composição de Lieder não cessou. Schumann manifestava uma grande exigência quanto à escolha dos poemas, e para ele um bom poema era condição essencial para se compor um Lied. No ano de 1840 Schumann escreveu um total de 138 Lieder.

Cientes destas informações, podemos retornar ao objeto do estudo: os Lieder de Clara.

Compostos para performance em concertos, os Lieder de Clara exigem um elevado nível artístico em sua execução. Obras de gosto refinado, contradizem a ideia errônea de que a produção feminina se restringe a peças sentimentais de

\footnotetext{
${ }^{6}$ A Neue Zeitschrift für Musik (Nova Gazeta Musical-lançada em 1834), além de lhe oferecer uma oportunidade de expressar suas ideias e a de seus companheiros, reais e imaginários, foi a responsável por seu estabelecimento como crítico e uma fonte de ganhos financeiros significativos

${ }_{7}$ Wieck tinha uma preocupação excessiva acerca da carreira de sua filha, e é importante frisar que, embora a carreira de prodígio estivesse em voga (e isso incluía as do sexo feminino), a mulher concertista era admitida pela sociedade apenas até se casar, quando a maioria delas deixava de tocar profissionalmente restringindo-se aos salões fechados, de ambiente familiar (SILVA, 2011, p.30).
} 
salão. Esquecidos nos dias atuais, os Lieder de Clara, em sua época, foram interpretados pelos melhores cantores do século XIX, nas principais salas de concerto.

De seus vinte e nove $\operatorname{Lieder}^{8}$, quinze foram editados, com número de opus, durante sua vida. São eles: op.12 - Er ist gekommen in Sturm und Regen, Liebst Du um Schönheit, Warum willst du and're fragen; Sechs Lieder op.13 - Ich stand in dunklen Träumen, Sie liebten sich beiden, Liebeszauber, Der Mond kommt still gegangen, Ich hab' in deinem Auge, Die stille Lotosblume; e Sechs Lieder aus Jucunde op.23 - Was weinst Du, Blümlein, An einem lichten Morgen, Geheimes Flüstern hier und dort, Auf einem grünem Hügel, Das ist ein Tag, der Klingen mag, $O$ Lust, o Lust. Outros três também foram publicados, mas sem número de opus: Walzer (1834), Am Strande (1841) e Mein Stern (1848). Os nove Lieder restantes, incluindo as primeiras versões de Ihr Bildnis e Sie liebten sich beide, foram editados postumamente em 1992 pela Breitkopf \& Härtel.

Como editor da Neue Zeitschrift für Musik, Robert escolhia os trabalhos a serem publicados no suplemento musical. Ele insistia para que Clara submetesse suas composições, mas ela não o fazia, nem antes nem depois do casamento. Ele negociava com os editores e organizava os trabalhos de Clara para as publicações. Ela não conseguiria essas publicações sozinha, pelo fato de ser uma jovem mulher casada.

As composições de Clara recebiam uma boa aceitação por parte do público, dos editores e dos seus contemporâneos - Félix Mendelssohn, Johannes Brahms, Robert Schumann entre outros.

Como prova desta recepção do público, encontramos este fragmento de carta do compositor e pianista Franz Liszt, à condessa d' Agoult: "Suas composições [de Clara Schumann] são realmente notáveis, especialmente para uma mulher. Há nelas cem vezes mais espontaneidade e sinceridade de sentimento que em todas as fantasias, antigas e atuais, de Thalberg"9 (LISZT apud REICH, 2001, p.195).

\footnotetext{
${ }^{8}$ Existem divergências em relação ao número de Lieder compostos por Clara. Duas peças de juventude Alte Heimath e Der Traum são conhecidas apenas por um programa de concerto datado de 1831. Der Wanderer e Der Wanderer in der Sägemule foram publicadas em 1875 como composições de Friedrich Wieck, há indícios de que essas composições foram escritas por Clara em parceria com seu pai. Por essas razões alguns autores preferem não incluir estas peças dentre suas composições.

${ }^{9}$ Sigismund Thalberg (1812-71) - pianista virtuoso aclamado pelo público.
} 
Outra prova da admiração de Liszt se vê pela transcrição feita dos Lieder. Warum willst du and're fragen, Ich hab' in deinem Auge e Geheimes Flüstern hier und dort, que foram arranjados em versão para piano solo, transcrições que foram publicadas em 1875.

Como material poético, selecionado por Clara, para a composição de seus Lieder estavam poemas de Friederich Rückert, Emanuel Geibel, Heinrich Heine, Hermann Rollett, Friederike Serre, Johann Wolfgang Von Goethe e traduções de Robert Burns. Estes eram os poetas favoritos de Robert, que provavelmente foi quem os apresentou a Clara. Estes poemas tinham como característica estrutural apresentar duas ou três estrofes e tratar de temas relacionados ao amor, à separação ou rejeição, à primavera e à natureza. Outros poemas se relacionavam às temáticas típicas do movimento Romântico: ansiedade, agitação, melancolia, mal do século, separação, morte e mistério.

Clara sempre foi, acima de tudo, uma intérprete, e sua formação foi direcionada nesse sentido. Ela não teve o poder nem a ambição de ser um dos líderes do 'Novo Romantismo', mas sempre foi aceita como um deles.

Como intérprete, Clara, orientada por seu pai, tinha noção do quanto dependia de seu público para seu sustento e projeção. Em função disso, algumas peças de gosto duvidoso ${ }^{10}$ faziam parte de seus programas de concerto, pois causavam furor entre os ouvintes. Mas ela não cedia apenas ao gosto do público, e em seus programas sempre estiveram presentes as obras de seus contemporâneos responsáveis pelas vanguardas musicais. Clara sabia como reconhecer o momento pertinente para introduzir uma peça mais ousada, de maneira que seu público não se sentisse chocado.

Clara era quase 10 anos mais nova do que Chopin, Mendelssohn e Schumann, entretanto tinha consciência das várias correntes musicais de seu tempo. Esses compositores tocavam suas obras para ela e ela também tocava suas composições para eles.

Clara conhecia bem os Lieder de seus coetâneos. Obras de Schubert, Mendelssohn, Fanny Hensel, estiveram presentes em seus programas de concertos desde a juventude. Depois de seu casamento, geralmente um ou dois Lieder de

10 O público tinha uma predileção por peças ligeiras, pois estas eram de mais fácil entendimento para os leigos. Apenas após o aumento do número de conservatórios na Europa - fator que permitiu ao público um maior conhecimento - é que foi possível aos compositores exporem suas ideias musicais mais livremente. 
Robert faziam parte de seus programas de concerto. E como intérprete desse gênero, identificava um problema que até hoje é recorrente entre os cantores. Observamos isso nas palavras de Nancy Reich:

Clara tinha uma postura definida em relação à interpretação do Lied alemão, e considerava deplorável o fato de muitos cantores não terem um entendimento consistente do texto. Para seu desapontamento, Pauline Viardot, uma cantora que ela admirava muito, mostrava mais interesse em efeitos vocais do que em transmitir a emoção inerente às palavras quando ela estava cantando Schubert (REICH, 2001, p.237).

Apesar de sua postura em relação à interpretação do Lied demonstrar a importância que dava ao texto nessas composições, percebemos, em suas obras desse gênero, uma predominância dos efeitos musicais. Provavelmente isso acontecia em função de sua atuação como pianista ser infinitamente maior do que sua proximidade com a literatura ${ }^{11}$. Sempre que necessário, seja por efeitos estéticos ou musicais, Clara se permitia fazer pequenas alterações no texto, repetindo palavras ou versos, contraindo palavras, alterando a ordem de palavras, ou até pulando um verso do poema ${ }^{12}$.

Apresentadas todas estas características, que são fundamentais para o estudo desta obra, seguiremos nosso estudo dialogando com fragmentos dos diários e da correspondência do casal, fontes primárias que são de fundamental importância para compreender peculiaridades do processo criativo desta compositora. O estudo desse material confirma a insistência de Robert para que Clara componha, deixando nítido também o pouco mérito que ela atribuía aos seus trabalhos, e em contrapartida, o total apreço de Robert a essas obras.

\footnotetext{
${ }^{11}$ Clara teve um tardio desenvolvimento da fala, talvez em função do conturbado ambiente familiar de sua infância - a separação dos pais quando ela tinha cinco anos. Sua educação sempre priorizou o estudo musical em detrimento aos outros conhecimentos. Isso diferia muito da realidade de Schumann - cujo pai tinha um próspero comércio de livros, responsável pela edição, tradução e publicação de diversas obras importantes na época. Esse grande acesso à literatura contribuía às dúvidas de Schumann entre a carreira de escritor e músico.

${ }^{12}$ Estes tipos de procedimentos foram também amplamente utilizados por Robert em suas composições.
} 


\subsection{OS ANOS DO CASAMENTO COM SCHUMANN}

\subsubsection{Em Leipzig}

O diário do casal Robert e Clara compreende os quatro primeiros anos de casamento, especificamente os anos em que viveram em Leipzig. Nele é narrada uma história de amor tipicamente romântica, marcada pelos exageros e pela dualidade. A ideia de escrever um diário partiu de Robert ${ }^{13}$, e no seu início ele escreve:

[...] tudo que nos afeta em nosso lar e em nosso casamento; nossos desejos e as esperanças, deve ser escrito aqui. Este será um livro de comunicação entre nós quando as palavras ditas não forem suficientes, um veículo de mediação e reconciliação quando nos desentendermos - em suma, um amigo bom e fiel a quem tudo confiaremos...

[...] Se estás de acordo, minha bem amada, assine seu nome aqui, abaixo do meu, e pronunciemos as três palavras nas quais repousa toda a felicidade da vida: TRABALHO, ECONOMIA, FIDELIDADE (SCHUMANN, R. apud SILVA, 2011, p.32).

Nos primeiros meses de casamento a casa dos Schumann recebia visitas frequentes de amigos importantes: compositores, editores, pianistas, músicos e poetas. As narrações de Clara demonstravam o quanto ela ficava feliz quando o casal tinha oportunidade de desfrutar momentos de estudo em conjunto - analisando e tocando prelúdios e fugas de Bach ou lendo grandes escritores como Shakespeare e Goethe, por exemplo. Em contrapartida, ela conta que, nesse período, a única coisa que a deixava triste era o rompimento com seu pai ${ }^{14}$.

Robert sempre desejou e incentivou Clara a compor Lieder, mesmo antes do casamento. Ele escreve, em uma carta datada de 13 de março de 1840: "Porque

${ }^{13}$ No romantismo era uma prática frequente dos artistas escrever diários. Temos outros exemplos célebres dessa prática com Wagner, Chopin, Brahms. Excertos destas publicações constarão deste estudo.

${ }^{14} \mathrm{O}$ rompimento com seu pai aconteceu em função do processo que ela e Schumann travaram contra seu pai, para conseguir a permissão judicial para o casamento. Esse rompimento teve seu fim apenas em dezembro de 1843, e depois de decorrido quase um ano desde a reconciliação com Clara, é que Wieck consegue se reconciliar com Robert, e é importante frisar que isso só ocorreu depois de muita insistência por parte de Wieck. 
não escrever um Lied! Uma vez começado, você não pode parar. Isto é simplesmente tentador" (SCHUMANN, C., 1992, prefácio) ${ }^{15}$.

Clara responde no dia seguinte:

Eu não posso compor. Isso me deixa, às vezes, infeliz, mas isso é realmente impossível. Eu não tenho talento para isso. Não pense que é por preguiça. Um Lied, você diz - não, eu simplesmente não posso. Para escrever um Lied, compreender o texto em seu sentido pleno - é preciso inteligência (SCHUMANN, C. apud PARSON, 2004, p. 157).

Robert faz mais uma tentativa em outubro de 1840, agora no diário do casal: "Eu dei à Clara um poema de Burns para ela compor; mas ela não se sentiu confiante o bastante" (SCHUMANN, C., 1992, prefácio).

Sob o encorajamento de seu marido, Clara escreve três Lieder para presenteá-lo no Natal de 1840, e nessa ocasião escreve no diário do casal:

Quando Robert estava fora, eu passei o meu tempo tentando compor uma música (que é o que ele gostaria), e eu finalmente consegui escrever três delas, as quais, eu quero oferecer-lhe no Natal. Elas naturalmente não têm nenhum valor e são apenas tentativas muito fracas; pelo menos eu posso contar com a clemência de Robert. Espero que ele pense que, ao menos, eu estava fazendo o meu melhor para cumprir o seu desejo, como eu faço com todos os seus desejos (SCHUMANN, C., 1992, prefácio).

Schumann ficou muito contente com os três Lieder: Am Strande, Volkslied e Ihr Bildniss, que ganhou de sua esposa no Natal, e confidencia sua aprovação no diário do casal:

Fiquei encantado com as três músicas, nas quais ela jorra como uma menina e que são muito mais precisas composicionalmente do que as anteriores. Nós agora temos a ideia inteligente de entremear algumas das minhas e tê-las impressas (SCHUMANN, C., 1992, prefácio).

A ideia de editar uma coletânea onde estariam presentes suas obras e também as de sua esposa motivou Robert a compor. No período de uma semana,

15 O prefácio desta publicação é de Joachim Draheim e Brigitte Höft. Schumann C. Sämtliche Lieder für Singstimme und Klavier. Prefácio DRAHEIM; HÖFT. Leipzig: Breitkopf \&Härtel Wiedsbaden, Band II, 1992. 
no início de janeiro de 1841, Schumann escreveu nove Lieder, todos com poemas do Liebesfrühling (Primavera de Amor) de Rückert. Ele insiste, novamente, para que Clara também compusesse, utilizando poemas dessa mesma coletânea.

Em janeiro de 1841, Schumann permanece trancado em seu quarto, dedicando-se exclusivamente à composição de sua primeira sinfonia - Sinfonia Primavera Op.39. Nos períodos em que estava compondo, Robert trancava-se no quarto do piano e não dirigia a palavra a sua esposa até que o trabalho fosse terminado, independentemente de quanto tempo isso durasse. Nesses períodos, Clara não tinha acesso ao piano, e tentava em vão musicar os poemas indicados por ele, confidenciando seu desespero no diário: "Muitíssimas vezes tentei por música nos poemas de Rückert, indicados por Robert, mas isso não avança nenhum passo, não tenho nenhum talento para composição"16 (SCHUMANN, sd, p.268).

Antes de completar um ano de casados, Clara começa a alternar em sua narração momentos de extrema felicidade nos quais não conseguia compreender como um homem tão maravilhoso como Schumann se interessou por ela assemelhando-se ao poema de Chamisso musicado por Robert em seu terceiro Lied do ciclo Frauenliebe und Leben - com momentos em que era tomada por profunda melancolia. Esses períodos são marcados por muita solidão e pela pergunta insistente: será que meu querido Robert ainda me ama? Sua tristeza era fruto da indiferença de seu marido quando este se dedicava exclusivamente à composição, sua angústia se agravava mais pelo fato de Clara ser privada de utilizar o piano nesses períodos. Essa situação deixava-a muito frustrada e também apreensiva quanto aos rumos de sua carreira, dada a impossibilidade de estudar.

Em março de 1841, pela primeira vez desde seu casamento, Clara apresentou-se em público. Essa reaparição aconteceu no mesmo concerto em que foi estreada a Primeira Sinfonia de Schumann, regida por seu amigo Mendelssohn. Robert ficou muito contente, pois nessa ocasião ele deixou de ser o marido da virtuose e viu seu nome no cartaz ao lado do de Clara.

Em junho de 1841, quando se aproxima o aniversário de Schumann, dia 08 de junho, Clara escreve no diário: "Esta semana compus muito, coloquei música em quatro poemas de Rückert para presentear Robert. Se ele se mostrar satisfeito - por menos que seja - meus desejos serão cumpridos" (SCHUMANN, sd, p.279).

\footnotetext{
${ }^{16}$ Note-se que "não tenho nenhum talento para a composição" é uma frase recorrente nos escritos de Clara.
} 
Os poemas musicados nessa ocasião são: Warum willst du and're fragen, Er ist gekommen in Sturm und Riegen, Liebst du um Schönheit e Die gute Nacht, die ich dir sagen. Schumann encontrava-se entretido em mais um trabalho, portanto não se expressa no diário, mas a própria Clara escreve a opinião de seu marido:

Os presentes que pude fazer a meu Robert eram pouquíssima coisa, mas ele sorriu com prazer, sabendo com que ternura eu os oferecia. Tinha um gosto especial pelos quatro Lieder com palavras de Rückert, julgou-os com tanta indulgência que deseja publicá-los com os seus, o que me encheu de alegria (SCHUMANN, sd, p.280).

Alguns dias depois, mais precisamente em 23 de junho de 1841, temos a comprovação da aprovação de Robert ao presente recebido em seu aniversário, pois ele escreve uma carta para o editor da Breitkopf \& Härtel:

Eu gostaria de dar para minha esposa um pequeno presente em seu aniversário, que é em meados de setembro: juntos, nós compusemos um número de Lieder de Rückert, que estão inter-relacionados como perguntas e respostas... Eu gostaria de oferecer a ela uma primeira versão impressa nesta data (SCHUMANN, C., 1990, prefácio) ${ }^{17}$.

Esses foram os primeiros Lieder de Clara a serem publicados após seu casamento. O projeto em conjunto, intitulado Zwölf Gedichte aus F. Rückert's Liebesfrühling inclui doze Lieder publicados em 13 de setembro de 1841 - dia do aniversário de Clara. Do total das peças, três ${ }^{18}$ são de Clara, e aparecem como o Op.12, as nove restantes são de Robert, publicadas como Op.37 de sua obra. Após a publicação Schumann envia uma cópia dos Lieder para Rückert, que fica muito feliz com o resultado musical de sua poesia. E decide demonstrar seu apreço a este trabalho, através de um poema de agradecimento, em maio de 1842. Este poema aparece transcrito por Clara no diário do casal.

No dia primeiro de setembro de 1841, um ano após o seu casamento, Clara dá a luz a primeira filha - Marie. Esse foi um mês de muitas comemorações, o

17 O prefácio desta publicação é de Joachim Draheim e Brigitte Höft. SCHUMANN, C. Sämtliche Lieder für Singstimme und Klavier. Prefácio DRAHEIM; HÖFT. Leipzig: Breitkopf \&Härtel Wiedsbaden, Band I, 1990.

${ }^{18} \mathrm{O}$ Lied Die gute Nacht, die ich dir sage, com poema da mesma coletânea de Rückert, não foi editado junto com as outras composições de Rückert, sua edição é apenas em 1992. 
aniversário de casamento, o de Clara, o batismo de Marie. Nos próximos treze anos, Clara teria mais sete filhos ${ }^{19}$.

Logo após as comemorações Schumann retoma suas atividades composicionais e Clara fica novamente afastada de seu piano para cuidar de sua filha. Apesar de ser essa a realidade comum às mulheres de sua época, a situação deixava Clara inquieta, pois seu desejo era voltar a tocar em público e principalmente viajar em turnês.

Em dezembro desse mesmo ano, os Schumann viajam em turnê para Weimar. Nessa breve viagem Clara pôde reencontrar a atmosfera do concerto, entretanto seu marido demonstra traços de instabilidade comportamental.

No verão do ano de 1842, Clara novamente compõe para presentear Robert, em seu aniversário, e dessa vez são dois Lieder: Liebeszauber, sobre poema de Geibel e Sie liebten sich beiden, sobre poema de Heine. Esse presente deixa Schumann realmente entusiasmado, e ele afirma, no diário do casal, que essas são as melhores composições de Clara até o presente momento.

No outono de 1842, Clara estava grávida novamente e Robert enfrentava uma de suas crises de nervos. Em virtude do esgotamento emocional e físico no qual se encontrava, Clara escreve no diário:

Desde há alguns dias, uma tristeza inexprimível pesa sobre mim. Acho que você não me ama mais como outrora. Sinto às vezes tão claramente que não poderei satisfazê-lo. E, se você me concede alguns sinais de ternura, tenho a impressão de devê-la à bondade do seu coração que não me quer fazer nenhum mal... Se você soubesse como meu coração transborda de amor por você, Robert! Como eu gostaria de supri-lo e fazer feliz sua vida! Como o amo infinitamente! Você é o único objeto das minhas preocupações. Não suporto a ideia de que você trabalhe para ganhar dinheiro... ${ }^{20}$ (SCHUMANN, C. apud LÉPRONT, 1990, p.86).

19 Provavelmente Schumann conhecia métodos contraceptivos, no entanto, o casal não adotava nenhum. Robert sentia-se feliz com cada gravidez de sua esposa, que por sua vez, tentava alegrar-se também com a chegada de cada criança (REICH, 2001, p.135).

${ }^{20}$ É muito interessante prestar atenção na última frase dessa narrativa de Clara, em sua época uma mulher assumir as responsabilidades financeiras da família era completamente contrário às convenções da sociedade. Nesse e em muitos outros aspectos da biografia de Clara nos deparamos com fatos que demonstram o quanto essa mulher era avançada para a sua época (SCHUMANN, C. apud LÉPRONT, 1990, p.86) 
Em janeiro de 1843, Clara reconcilia-se com seu pai e chega a passar uns dias na casa dele em Dresden. Schumann tinha orgulho e reconhecia o talento de Clara, escrevendo em um dos seus artigos:

A grande influência na profissão dele (Schumann) foi seu casamento com um dos maiores artistas de nosso século, a admirável Clara Wieck. Schumann viveu na casa do pai dela por muitos anos... Ao contrário de outros virtuoses, ela prefere evitar tocar suas próprias composições, embora ela componha melhor e de maneira mais sólida do que muitos artistas famosos deste período (SCHUMANN, R. apud REICH, 2001, p.214-15).

Ao mesmo tempo ele era um homem do século XIX, que partilhava a ideia de que a dedicação principal de uma mulher deveria ser a família. Em 17 de fevereiro de 1843 ele escreve no diário do casal:

Clara tem escrito um número de pequenas peças que mostram uma invenção que ela nunca tinha atingido antes. Mas ter filhos e um marido que está sempre nos reinos da imaginação não é compatível com a composição. Ela não pode trabalhar regularmente e estou sempre incomodado em pensar quantas idéias profundas são perdidas porque ela não pode trabalhá-las. Mas Clara mesma sabe que sua ocupação principal é ser mãe, e eu acredito que ela seja feliz com as circunstâncias e que não gostaria de mudá-las (SCHUMANN, R. apud REICH, 2001, p.215).

No dia 18 de fevereiro desse mesmo ano, os Schumann saem em turnê novamente, mesmo Robert estando doente. Durante a viagem Robert escreve no diário: "Fevereiro, 26. Clara foi à corte e retornou radiante pela sua recepção. Mas o pensamento do papel sem dignidade que represento nessas ocasiões impediu-me de sentir a menor alegria" (SCHUMANN, R. apud REICH, 2001, p.89).

Essa situação agravou-se ainda mais, Robert cansou-se de ouvir o público perguntando a ele se também se dedicava a música. Isso o levou a deixar sua esposa sozinha e voltar para Leipzig:

Devo negligenciar a minha arte para acompanhar você em viagem? $E$ você, por sua vez, não deve utilizar seu talento porque eu estou comprometido com a Revista e com meu piano? Descobrimos uma solução: você leva uma companheira de viagem, e eu retomo o meu lugar ao piano, fazendo meu trabalho, junto de nossa filha. Mas o que vão dizer? (SCHUMANN, R. apud LÉPRONT, 1990, p.82). 
Clara também ficou infeliz, sentiu muita falta de seu marido e saudade de sua filha: "Cometi uma das maiores bobagens quando deixei você se afastar de mim, percebo cada vez melhor agora"21 (SCHUMANN, C. apud LÉPRONT, 1990, p.82).

Mesmo com toda a insatisfação de Robert, Clara não parou de se apresentar em concertos e viajar, antes e logo após o nascimento de sua segunda filha - Elisie em abril de 1843. Ambos sabiam que Clara poderia ganhar mais dinheiro em apenas três semanas de turnê do que Robert em um ano inteiro compondo e editando, e nessa época até mesmo Robert passa a reconhecer que eles necessitavam de mais dinheiro.

Em 1843, Clara compõe mais três Lieder, novamente para o aniversário de Robert: Lorelei, sobre poema de Heine, Ich hab' in deinem Auge e Oh weh des Scheidens, sobre poemas de Rückert. Schumann faz um comentário não muito entusiasmado sobre as obras, pois é muito provável que estivesse novamente focado exclusivamente em suas próprias obras.

Em 6 de agosto de 1843 Schumann novamente envia uma carta para a Breitkopf \& Härtel: "Minha mulher envia suas lembranças e um pequeno livro de Lieder que ela gostaria de publicar em breve. Nós vamos determinar o título completo assim que tivermos resposta da rainha de Copenhague, a quem ela gostaria de dedicá-los" (SCHUMANN, C., 1990, prefácio).

O livro de Lieder $^{22}$ a que Schumann se refere nessa carta foi editado em janeiro de 1844, Op. 13 da obra de Clara, e dedicado à Caroline Amalie, rainha da Dinamarca. Esta coletânea de peças inclui: Ich stand in dunklen Träumen (Heinrich Heine, dezembro de 1840); Sie liebten sich beiden (Heine, junho de 1842);

\footnotetext{
${ }^{21}$ No século XIX, não era uma prática frequente uma mulher casada viajar sozinha, portanto, Robert tinha de acompanhá-la em suas turnês, o que the trazia grandes crises. Ele não gostava de deixar sua casa, seus filhos, seus trabalhos editoriais e principalmente a paz e a calma que tanto necessitava para compor. Geralmente ele ficava doente antes mesmo da turnê iniciar.

22 Podemos considerá-lo como uma coletânea de Lieder, e não um ciclo. Encontramos algumas confusões no que diz respeito à diferença entre coletânea e ciclo. O problema acontece no fato de que não necessariamente Lieder editados juntos, com um mesmo título ou mesmo número de opus formem um ciclo que deva ser interpretado como uma unidade. Muitas vezes eles foram agrupados por uma conveniência editorial. É preciso observar se existe algum tipo de conexão, seja ela harmônica ou em função do sentido poético, que ligue os diferentes Lieder editados juntos. O intérprete deve ter um cuidado especial na interpretação de um ciclo para que as relações musicais - motivos recorrentes, gestos musicais, texturas - responsáveis pela unidade, sejam perceptivas ao ouvinte. O intérprete precisa ser meticuloso ao ponto de pensar qual é o tempo necessário de intervalo dentre as peças, pois este tempo não é igual entre todas, e depende da jornada psicológica do personagem.
} 
Liebeszauber (Emanuel Geibel, junho de 1842); Der Mond kommt still gegangen (Geibel, julho de 1843); Ich hab' in deinem Auge (Friedrich Rückert, junho de 1843) e Die stille Lotosblume (Geibel, julho de 1843).

O Op. 13 inclui a segunda versão de dois poemas de Heine - Ich stand in dunklen Traumen (Ihr Bildniss - na versão original) e Sie liebten sich beide. É interessante notar que diferentes autores relatam que, nos dois casos, a primeira versão dessas peças é mais ousada harmonicamente do que a segunda.

Em 1844, Clara faz uma extensa turnê pela Rússia. Robert havia decidido não mais acompanhar a esposa em suas turnês, pois essas não o agradavam e traziam sérios problemas para sua saúde. Entretanto, depois de muito pensar, decide acompanhá-la, pois a última separação deles por conta de uma turnê havia sido muito penosa. As condições da turnê foram muito adversas em função do rigoroso inverno, mas mesmo com todas as dificuldades Clara demonstrava muita energia e tocava brilhantemente, sendo aclamada em todos os concertos. Assim, conseguiu ganhar pelo menos o dobro do valor que tinha sido acordado anteriormente, mas seu marido enfrenta sérios problemas emocionais, certamente a pior crise desde seu casamento.

Os Schumann retornam a Leipzig. Robert ainda está seriamente doente, portanto Clara precisa esquecer o glamour e a fama que experimentou nos dias passados na Rússia e retomar sua vida de mãe, esposa e dona de casa.

Em junho de 1844 Robert decide passar a edição da Neue Zeitschrift para Oswald Lorenz. Havia criado essa revista e esteve à frente de sua edição durante dez anos. Em agosto desse mesmo ano, Robert enfrenta novamente uma grave crise de nervos e visando a melhora de sua saúde fazem uma pequena viagem para uma região de montanhas. Clara estava grávida de seu terceiro filho e já planejava uma nova turnê, mas abdica de suas intenções, dedicando todo o seu tempo à recuperação de seu marido. Eles decidem visitar Dresden, talvez novos ares ou novas distrações pudessem melhorar o estado de Robert, e em uma decisão repentina deixam Leipzig e se mudam para Dresden.

\subsubsection{Em Dresden}


Diferentemente do período em Leipzig - onde as principais informações sobre o casal Schumann são encontradas no Diário de Casamento - e possivelmente em função dos problemas de saúde de Robert, os quais ele preferia não discutir com sua esposa, as informações sobre esses anos passam a ser relatadas nas cartas trocadas com os amigos.

A princípio parece difícil entender por que o casal Schumann decidiu se mudar tão repentinamente, deixando para trás uma cidade que os dois amavam e que efervescia culturalmente ${ }^{23}$. Dresden era uma cidade que vivia da lembrança de seu passado glorioso, que apreciava a pintura e a literatura contanto que estas não fossem muito subversivas. Clara acreditava que, para a música, Dresden era um fim de mundo com habitantes retrógrados ${ }^{24}$, mas, em contrapartida a cidade tinha um ambiente salubre que poderia auxiliar no tratamento de Robert, uma vez que até então os demais tratamentos não tinham surtido efeito.

Nos anos em Dresden a carreira de Clara abrandou um pouco; apresentou-se em apenas 12 concertos nos anos de 45 e 46, e isso aconteceu por vários motivos: a saúde abalada de Robert fazia com que ela tivesse de acompanhá-lo e dar suporte a todas as suas atividades; ela precisou assumir quase que todas as responsabilidades, inclusive as financeiras, além das obrigações de esposa e mãe. Durante a vida de casada, Clara seguia a maioria das tarefas de uma esposa de músico: copiava música, acompanhava os grupos que seu marido regia, tocava e cantava as obras dele em concertos. E, como era uma pianista reconhecida, fazia também a primeira audição das peças de Robert, além de preparar arranjos para piano de peças instrumentais que ele compunha.

Refletindo o pensamento de sua época, essa esposa - apesar de sua educação musical privilegiada e os anos de experiência no mundo musical acreditava que seu marido era a autoridade máxima em todas as coisas, sejam elas musicais ou não.

\footnotetext{
${ }^{23}$ A Gewandhaus Orchestra alcançava o mais alto nível da Europa, o conservatório estava começando triunfante - o treinamento profissionalizante em música passa a existir somente após a Revolução Francesa, até então as pessoas aprendiam música em casa com membros da família ou estudavam com professores particulares - os moradores se orgulhavam de suas livrarias e das multidões de leitores, os jornais musicais da cidade circulavam pelo mundo e as editoras de música de Leipzig eram prestigiadas em toda a Europa.

${ }^{24} \mathrm{O}$ regente da orquestra do teatro real se recusava a executar as sinfonias de Beethoven, que poderiam comprometer o concerto de domingo pela ausência de público.
} 
Nos anos vividos em Dresden nasceram seus outros quatro filhos, e ela ainda sofreu um aborto. No dia 11 de março de 1845 nasceu Julie; dia 08 de fevereiro de 1846 nasceu Emil, o primeiro filho homem. Em contrapartida, o retorno a Dresden, onde Clara deu seu primeiro concerto aos dez anos de idade, trazia boas recordações e também a reaproximava de seu pai, que continuava vivendo na cidade.

Nos dois primeiros anos em Dresden a produção composicional de Clara foi significativa. Apesar do estresse causado pela doença de seu marido, ela compôs seus Drei Praeludien und Fugen für das Pianoforte op.16 e o Trio für Pianoforte, Violine und Violoncello op.17.

No dia 23 de novembro de 1846, Clara e Robert partem em turnê para Viena. Para conseguir levar seu marido, ela alegava que tinham dificuldades financeiras e também que a obra dele precisava ser divulgada na Áustria. Mas possivelmente a razão principal era o seu desejo sempre renovado de apresentar-se em público. Clara não foi muito bem sucedida em seus primeiros concertos em Viena, pois não era mais uma criança prodígio e o público preferia as obras italianas e o repertório dos virtuoses. Esse tipo de repertório não fazia mais parte dos concertos de Clara, que amadurecera muito musicalmente. Para o público retrógrado desta cidade, a música de Schumann era séria demais.

Clara ficou muito frustrada. Nem o sucesso conquistado nos outros concertos da turnê fez com que ela superasse esse sentimento. Ela decide, então, ir a Berlim, na esperança de receber uma boa acolhida. Mas a cidade estava em ebulição em função de uma crise econômica, e Clara não foi bem sucedida.

No retorno para Dresden, Robert se sentia um pouco melhor e eles desfrutaram de alguns momentos de estabilidade. Robert retomou suas composições. No dia 21 de junho de 1847 morre Emil. Clara passava por um período difícil, o concerto frustrado em Viena e também o sentimento de culpa por ter deixado seu filho doente para ir a Berlim em busca de um concerto bem sucedido deixaram-na abalada. Schumann estava num período de recuperação, amparando sua esposa, novamente grávida. Porém, no dia 04 de novembro de 1847 a morte de Mendelssohn deixa Robert muito abalado. Clara é obrigada a assumir todas as responsabilidades novamente. No dia 20 de janeiro de 1848 nasceu seu quinto filho - Ludwig. 
No período em que estiveram em Dresden, e apesar dos problemas de saúde e da depressão que angustiavam muito Robert, ele compõe muitos de seus grandes trabalhos. A cidade passara por momentos turbulentos, causados pelo Levante de Maio. Os rebelados contra os governos absolutistas, que continuavam na Europa após a Proclamação da República na França alistavam todos os homens da região. Robert simpatizava com os rebeldes, mas seu estado de saúde impossibilitava-o de lutar, portanto ele e Clara viram-se obrigados a fugir para uma cidade vizinha na calada da noite, deixando para trás seus filhos. Clara, grávida de sete meses, é obrigada a retornar a Dresden acompanhada pela filha de um pastor da região para levar os filhos e os empregados para um abrigo no subúrbio. Eles ficam fora da cidade por quase um mês.

A insurreição da cidade inspirava em Robert cantos libertários e marchas, mas ao mesmo tempo também obras serenas, que chegavam a deixar Clara espantada. Como era possível que tantas cenas horrorosas despertassem em alguém sentimentos poéticos tão diferentes da realidade vivenciada? Em Abril de 1849 Schumann escreve a um amigo relatando que este estava sendo seu ano mais produtivo. No dia 06 de julho de 1849 Clara deu a luz ao seu sexto filho, Paul Ferdinand.

Schumann é convidado para ocupar o cargo de Diretor da Orquestra e do Coro do Município de Düsseldorf; com sua saúde cada vez pior, o casal decide aceitar a proposta e se muda novamente.

\subsubsection{Em Düsseldorf}

A adaptação nessa cidade luminosa e ensolarada, movimentada pelo comércio de manufaturas e pela vida intelectual, foi difícil, apesar da calorosa recepção recebida.

A mudança custara muito mais do que o previsto, e neste momento as questões financeiras deixavam Clara muito preocupada. As mudanças do casal sempre se relacionavam às tentativas de melhora na saúde de Robert, mas desta vez ele entrara em um estado de extremo nervosismo devido ao barulho constante. 
Para trabalhar Robert necessitava de silêncio para conseguir se concentrar, e justamente em seu quarto escutava-se o barulho vindo da rua, das crianças gritando, realejos, carruagens, e isso fazia com que o esforço para realizar seu trabalho fosse ainda maior.

Clara estava sempre ocupada com as atividades domésticas, o que a deixava angustiada, pois se via impedida de estudar. Nestes últimos anos as mudanças de cidade, o número crescente de filhos, e principalmente, a assistência ao seu marido - que se mostrava cada vez mais abalado emocionalmente - tomavam todo o seu tempo.

O trabalho com a orquestra e o coro da cidade deixava Schumann cada vez mais nervoso e intolerante. O compositor tinha dificuldades de comunicação e Clara acabava sendo seu porta-voz com os músicos. Em 01 de dezembro de 1851 nasce Eugenie.

Em 1852 a saúde de Robert piorava e por recomendação médica o casal viaja para uma estação de águas na Holanda. Na ocasião Clara vivencia uma situação de quase morte, provocada por um aborto, e essa experiência altera a sua postura em relação ao seu casamento. A jovem obstinada com a preocupação pelos problemas familiares dá lugar a uma mulher que conhece suas necessidades e se preocupa com seus interesses. Clara exige que a família se mude para um local onde ela tenha um cômodo com piano exclusivamente para o seu uso. Isso possibilita que retome sua carreira de pianista e seus trabalhos composicionais.

Clara retoma a composição. Escreve seus opus 20, 21, 22 (Drei Romanzen für Pianoforte - dedicado a Joseph Joachim) e 23. Volta a planejar uma turnê, mas uma nova gravidez muda seus planos mais uma vez.

No dia 10 de junho de 1853, Clara relata em seu diário: "Compus dois Lieder com poemas do 'Jucunde' de Hermann Rollett. Compor essas peças me fez muito feliz. Eu escrevi meu último Lied em 1846 - sete anos atrás!" (SCHUMANN, C., 1990, prefácio).

No dia 22 de junho ela escreve:

Agora eu tenho um livro de Lieder com o qual estou satisfeita e que me proporcionou momentos muito felizes... Não há nada melhor do que criar suas próprias coisas, mesmo que seja apenas para desfrutar horas de auto-esquecimento, onde se respira somente música... (SCHUMANN, C., 1992, prefácio) 
Clara se referia, em seu diário, ao seu Op. 23, composto entre 9 e 21 de junho de 1853, com poesia de Hermann Rollett, poeta austríaco; este ciclo de Lieder foi publicado pela Breitkopf \& Härtel em 1856. Clara dedicou-os a Lívia Frege, cantora que iniciou a carreira na mesma época que ela, apresentando-se na Gewandhaus de Leipzig.

A origem desse ciclo também está relacionada ao seu marido. Robert, em janeiro de 1853, ao ler Jucunde, comentou com Clara que esses versos eram extremamente musicais, e essa afirmação provavelmente despertou o interesse de sua esposa. Reich (2001, p. 239) afirma que uma das últimas cartas de Schumann antes de sua hospitalização, escrita para Hermann Rollett, poeta que acreditava que Schumann era o responsável pela composição dos Lieder utilizando suas poesias, afirmava que essas composições eram de sua esposa, acrescentando que ao mesmo tempo, adoraria que isso não fosse um equívoco. Esta afirmação de Schumann já seria suficiente para termos ideia da qualidade desses Lieder de Clara, mas julgamos pertinente apresentar algumas outras opiniões relativas a essas peças:

Sobre o Op. 23 de Clara Schumann, afirmou Luís Antônio Giron:

A marca pessoal se afirma no Op.23, conjunto que exibe variedade de recursos e invenção de melodias inesperadas. A leitura se torna melancólica diante dos poemas de Hermann Rollett, um metafísico tardo-romântico. Ouça então o traço mais forte, a reticência do acompanhamento pontilhista, a síntese e até o borrão modulatório que lembra Richard Strauss e Gustav Mahler. ${ }^{25}$

Reich (2001, p. 239) afirma que:

Apesar de os textos serem simples e sentimentais, as composições não são. O piano e as linhas vocais no Op. 23 mostram maior independência e os acompanhamentos têm maior variedade rítmica e flexibilidade do que os Lieder anteriores.

Concluímos nosso estudo biográfico com as palavras de James Deaville: "O que vemos é uma compositora certa de seu ofício, que não precisa recorrer ao comprimento ou hipérbole para fazer uma afirmação" (PARSON, 2004, p. 157).

${ }^{25}$ GIRON, L. A. As composições Autocríticas de Clara Schumann. Disponível em: http://www.reocities.com/Vienna/8179/clar.html Acesso em: 30.jul.2011. 


\subsection{LISTA CRONOLÓGICA DOS LIEDER DE CLARA}

A Tabela 1 contempla todos os Lieder de Clara Schumann. Apresenta uma lista cronológica com o título, indicação do nome do poeta, a data em que foi feito e a data de sua publicação.

Tabela 1 - Lista cronológica dos Lieder de Clara Schumann

\begin{tabular}{|c|c|c|c|}
\hline Título & Poeta & Composição & Publicação/Opus \\
\hline Der Abendstern & $?$ & $?$ & 1992 \\
\hline Walzer & $\begin{array}{c}\text { Johann Peter Lyser } \\
(1804-1870)\end{array}$ & 1834 & 1834 \\
\hline Am Strande & $\begin{array}{l}\text { Robert Burns } \\
(1759-1796)\end{array}$ & Dezembro, 1840 & 1841 \\
\hline $\begin{array}{l}\text { Ich stand in } \\
\text { dunkeln Träumen } \\
\text { (Ihr Bildnis) }\end{array}$ & $\begin{array}{c}\text { Heinrich Heine } \\
(1797-1856)\end{array}$ & Dezembro, 1840 & 1843, op 13 no. 1 \\
\hline Volkslied & Heine & Dezembro, 1840 & 1992 \\
\hline $\begin{array}{l}\text { Warum willst } d u \\
\text { And're fragen? }\end{array}$ & $\begin{array}{c}\text { Friedrich Rückert } \\
(1788-1866)\end{array}$ & 8, Junho, 1841 & 1841 , op.12 no.11 \\
\hline $\begin{array}{c}\text { Er ist gekommen } \\
\text { in Sturm und } \\
\text { Regen }\end{array}$ & Rückert & 8, Junho, 1841 & 1841, op.12 no. 2 \\
\hline $\begin{array}{l}\text { Liebs du um } \\
\text { Schönheit }\end{array}$ & Rückert & 8, Junho, 1841 & 1841 , op. 12 no. 4 \\
\hline $\begin{array}{l}\text { Die gute Nacht, } \\
\text { die ich dir sage }\end{array}$ & Rückert & 8, Junho, 1841 & 1992 \\
\hline $\begin{array}{l}\text { Sie liebten sich } \\
\text { Beiden }^{26}\end{array}$ & Heine & 8, Junho, 1842 & 1843, op13 no.2 \\
\hline $\begin{array}{c}\text { Liebeszauber (Die } \\
\text { Liebe sass als } \\
\text { Nachtiaall) }\end{array}$ & $\begin{array}{c}\text { Emanuel von Geibel } \\
\quad(1815-1884)\end{array}$ & 8, Junho, 1842 & 1843, op. 13 no. 3 \\
\hline $\begin{array}{l}\text { Die stille } \\
\text { Lotosblume }\end{array}$ & Geibel & Julho, 1842 & 1843, op.13 no.6 \\
\hline $\begin{array}{l}\text { Der Mond kommt } \\
\text { still gegangen }\end{array}$ & Geibel & Julho, 1842 & 1843, op.13 no. 4 \\
\hline
\end{tabular}

${ }^{26}$ Essa composição possui duas versões. 
(Continuação Tabela 1)

\begin{tabular}{|c|c|c|c|}
\hline Lorelei & Heine & 8, Junho, 1843 & 1992 \\
\hline $\begin{array}{c}\text { Ich habe in } \\
\text { deinem Auge }\end{array}$ & Rückert & 8, Junho, 1843 & 1843, op.13 no.5 \\
\hline $\begin{array}{c}\text { O weh des } \\
\text { Scheidens, das er } \\
\text { tat }\end{array}$ & Rückert & 8, Junho, 1843 & 1992 \\
\hline Beim Abschied & $\begin{array}{c}\text { Friederike Serre } \\
(1800-1872)\end{array}$ & Junho, 1846 & 1992 \\
\hline Mein Stern & Serre & Junho, 1846 & 1848 \\
\hline $\begin{array}{l}\text { Was weinst } d u \\
\text { Blümlein? }\end{array}$ & $\begin{array}{c}\text { Hermann Rollett } \\
(1819-1904)\end{array}$ & 9, Junho, 1853 & 1855, op.23 no.1 \\
\hline $\begin{array}{l}\text { Geheimes } \\
\text { Flüstern }\end{array}$ & Rollet & 10, Junho, 1853 & 1855, op.23 no.2 \\
\hline $\begin{array}{c}\text { An einem lichten } \\
\text { Morgen }\end{array}$ & Rollet & 13, Junho, 1853 & 1855, op.23 no.3 \\
\hline $\begin{array}{c}\text { Auf einem grünen } \\
\text { Hügel }\end{array}$ & Rollet & 16, Junho, 1853 & 1855, op.23 no.4 \\
\hline O Lust, o Lust & Rollet & 19, Junho, 1853 & 1855 , op.23 no.5 \\
\hline Das ist ein Tag & Rollet & 21, Junho, 1853 & 1855, op.23 no.6 \\
\hline Das Veilchen & $\begin{array}{l}\text { Johann Wolfgang } \\
\text { von Goethe } \\
(1749-1832)\end{array}$ & 7, Julho, 1853 & 1992 \\
\hline
\end{tabular}


2 O LIED 


\title{
2.1 CONSIDERAÇÕES
}

A palavra Lied conota brevidade, simplicidade de expressão e construção estrófica $^{27}$. O gênero Lied é uma fusão de duas linguagens artísticas - poesia e música - pensado para ser cantado tendo sua forma e conteúdo adequados para tanto. Dependendo do período ou do compositor em questão, um ou outro elemento pode dominar. Na relação ideal entre eles, música e palavra têm o mesmo peso.

\begin{abstract}
Hegel afirma que a fusão entre essas duas artes aparece primeiramente na forma de Volkslied, alcançando seu nível máximo de elaboração com o Lied. Segundo o filósofo entre música e poesia há maior afinidade porque ambas utilizam o mesmo elemento sensível, o som. Entretanto as duas artes empregam o som de maneiras distintas. A poesia usa o som para expressar sinais e designações verbais, nestes a objetividade e a exterioridade são imanentes, em outras palavras, ela realiza um caminho que consiste em apreender e transformar as intuições e sentimentos em um mundo total de acontecimentos e ações. Já a música faz do próprio som o seu elemento e trata-o como a um fim, ela é a arte com capacidade de libertar-se de qualquer texto e também de qualquer expressão. Ela é realizada apenas com as modulações, justaposições e harmonia, mas só é elevada a uma condição de verdadeira arte quando os sons significam algo (QUADROS, 2008, p.1).
\end{abstract}

No Lied, um dos componentes - o verso - é originalmente um trabalho independente. Esta é a única forma de composição musical que regularmente faz uso de outro trabalho artístico na íntegra, previamente criado, sem a preocupação de uma possível musicalização, e que apresenta elementos poéticos musicais em si mesmo. Embora nesse gênero musical seja utilizado um trabalho conciso (um poema) como uma parte integral, a relação é diferente da que acontece na ópera. Nesta há a adaptação de um trabalho pré-existente, no Lied há a absorção, sem modificações, de um trabalho inteiro.

Uma composição de Lied é o resultado de uma interpretação de um poema feita por um compositor. O poema isoladamente permite várias leituras e discussões, entretanto a partir do momento em que ele é musicado nos deparamos com a

\footnotetext{
${ }^{27}$ Apesar da ideia de simplicidade estar associada a esse gênero, os grandes mestres do Lied, são assim considerados pelas suas composições de forma singular e complexidade de criação.
} 
representação musical da interpretação poética realizada por uma pessoa específica, o compositor ${ }^{28}$.

Ao pensarmos no gênero Lied, normalmente somos remetidos ao período denominado Romantismo. Realmente não podemos dissociar este gênero deste momento histórico, mas isso não significa que ele surgiu nessa época. Definir o início do Lied é uma tarefa complexa que envolve opiniões diversas. Alguns autores utilizam a terminologia: Primeira e Segunda Escola de Berlim, o que centraliza o desenvolvimento desse gênero apenas naquela cidade. Parece-nos mais pertinente aceitar o início do Lied no século XVIII, momento em que os compositores rompem com a tradição do barroco, deixando de utilizar o baixo cifrado em prol da escrita de uma parte específica de piano. Este fenômeno aconteceu em diferentes regiões, cujo idioma é o alemão.

A nova arte demorou algumas décadas para desenvolver sua forma. 0 ambiente intelectual não propiciava seu crescimento, negava-se à música a posição de igualdade com a poesia. A música era apenas um auxiliar para a expressão poética, e essa postura não condiz com o desenvolvimento do Lied como uma forma artística independente.

O florescimento do Lied no século XIX tornou-se possível em função do desenvolvimento literário acontecido no século anterior. A relação entre música e poesia, que já havia sido explorada por diferentes compositores durante os séculos anteriores, encontrou nova vitalidade e significado no Lied Romântico.

Para entendermos o desenvolvimento do Lied é imprescindível estudar a postura dos compositores e intérpretes desde o seu início. Durante o século XVIII, os países de idioma alemão, especialmente os mais ao norte, desenvolveram uma forte tradição de Lied. Gênero escrito utilizando o idioma alemão, e, principalmente, conectado a esta cultura, chegando a ser promovido a um símbolo do sentimento nacionalista.

${ }^{28}$ Observamos que na maioria dos casos o julgamento de qualidade de um Lied depende muito mais da parte musical do que da poesia. Encontramos um poema acompanhado de uma composição fraca, limitada no entendimento do texto e o contrário também é possível, mas é curioso notar que este caso é geralmente mais bem aceito, provavelmente porque os intérpretes se interessam muito mais pela beleza musical e também porque o ouvinte não consegue captar toda a riqueza do poema em muitas das composições do século XIX. 
O modelo folclórico do Lied (volkstümlich) concedia à poesia a primazia, deixando a música como suporte das palavras, promovendo o correto exame crítico e emocional, não devendo ir além disso.

É de fundamental importância compreender os fatores históricos que impulsionaram o sentimento nacionalista nessa região, berço do gênero artístico em questão. O crescimento desse sentimento trouxe inovações poéticas, estimulando a música a buscar sua posição de igualdade em relação à poesia.

Com os compositores românticos, a música conquistou importância e passou a ser um rival ao domínio da poesia. O modelo folclórico ideal lentamente transformou-se, promovendo uma paridade entre música e palavras, o que motivou maior complexidade às composições e aos acompanhamentos. Com a igualdade foi possível o desenvolvimento desse gênero.

\subsection{O LIED NO SÉCULO XVIII}

Não há dúvidas de que o Lied do século XVIII era direcionado pelo mercantilismo. Essas composições eram cantadas por amadores em casa ou em salões literários e voltadas para o divertimento e consumo imediato. A premissa de acessibilidade e popularidade do Lied naquele momento precisa ser lembrada quando o interesse é compreender o gênero e o fundamento que the foi concedido no próximo século.

Provavelmente os compositores de Lied do século XVIII não aspiravam por aplausos ou pela permanência de um cânone musical. Não tinham o interesse de inventar um gênero artístico para a posteridade. Eles eram atraídos pelo desejo de escrever uma música agradável que satisfizesse os anseios da época.

Os editores desejavam que o Lied fosse a solução para os excessos da ópera Italiana - gênero artístico da classe alta. A simplicidade do Lied promovia o prazer e a alegria de toda a sociedade. A ideia de mercantilismo, associada à simplicidade do Lied nesse período, nos faz compreender a razão pela qual muitos compositores posteriores opuseram-se a esse gênero musical ${ }^{29}$.

\footnotetext{
${ }^{29}$ Em 1839 Schumann chega a escrever em seu diário que jamais escreverá um Lied, pois este é um gênero menor que não merece sua atenção (GORRELL, 1993, p.127).
} 
O entendimento do Lied no século XVIII pode nos levar a reavaliação de algumas inovações, que por muitos estudiosos são creditadas aos compositores do século XIX. As sementes para a integração cíclica foram plantadas ainda no século XVIII; iniciar a composição não com a tônica, mas com outra harmonia, sempre associado a Schubert, também teve suas raízes nesse século.

Ainda hoje, para os críticos acostumados a fixar o nascimento do Lied em 19 de outubro de 1814 - dia em que Schubert compôs Gretchen am Spinnrade - a tentação de ignorar as composições anteriores a essa data é muito forte.

O Lied, do século XVIII e XIX, é o resultado da busca dos poetas alemães por um novo direcionamento. O desejo de naturalidade e simplicidade não é uma consequência do Volkslied ${ }^{30}$ de Johann Gottfried Herder (1744-1803) de 1770, nem do tratado de Christian Gottfried Krause (1719-1770) de 1753. Essa nova diretriz foi iniciada no período de transição do barroco para o neoclassicismo, por J.C. Gottsched (1700-1766) - professor de poesia da Universidade de Leipzig - que em seu Versuch einer critischen Dichtkunst (1730) afirma que os compositores de música deveriam lutar por uma leitura agradável e clara do poema, respeitando a essência e o conteúdo das palavras. O intuito era uma observação exata da natureza evitando a artificialidade, característica associada ao período Barroco. $\mathrm{O}$ tratado de Gottsched afirma que qualquer coisa escrita deve ser modesta e simples. Tal ideia era compartilhada por Friedrich Von Hagedorn (1708-1754), no prefácio de sua Oden und Lieder de 1742, por seu discípulo J.A. Scheibe (17081776) e pelo poeta Johann Peter Uz (1720-1796).

Para tanto era necessário distanciar-se da poesia que trazia inovações em cada verso, o fluxo grande de informações fazia com que o ouvinte não conseguisse desfrutá-las. Assim, era melhor imbuir um poema de regularidade e delicadeza, um estilo fácil e fluente, possuidor de uma inteligência elegante, utilizando uma forma simples e uniforme.

Scheibe, aluno de Gottsched, estabeleceu as diretrizes relativas à maneira como o compositor poderia responder à poesia. Ele aconselhava o compositor a iniciar seu trabalho com uma consideração sobre a forma geral do poema. Dada a natureza invariavelmente estrófica da poesia contemporânea, o músico deveria ter o cuidado de adequar a música a cada estrofe, respeitando o tipo de verso e a métrica

${ }^{30}$ Este tema será desenvolvido no decorrer deste capítulo, no item 2.3.1 Histórico. 
do poema. O compositor não deveria criar uma cadência, repetir uma palavra, ou estender uma sílaba em uma estrofe se ao fazê-lo comprometesse outra. Isto feito, a última etapa da composição era a criação de uma melodia relativamente curta, que fosse livre, fluente, pura e realmente natural, e que pudesse ser cantada "imediatamente sem esforço especial por alguém inexperiente em música" (SCHEIBE apud GROVE, 2001, p.669, v.14).

O Lied proporcionou às terras alemãs o que poderia ser chamado de uma identidade musical nacional. Começando com Leibniz na década de 1680, cada vez mais escritores se manifestaram sobre a cegueira forçada que caracterizava o modo de viver, de falar, de escrever ou até mesmo de pensar, escravos de uma tradição francesa.

Christian Thomasius, professor da Universidade de Leipzig, criticando essa característica cultural, asseverou em 1687: "se os nossos antepassados alemães ressuscitassem dentre os mortos... eles pensariam que estavam em uma terra estrangeira" (THOMASIUS apud PARSON, 2004, p.61). Telemann afirmou em sua coleção de 1741 não apenas o seu desejo por uma "renovada idade de ouro das notas", mas também a intenção de "mostrar aos estrangeiros que somos capazes de pensar de maneira mais madura do que vocês!" (TELEMANN apud PARSON 2004, p.61).

De igual maneira, Krause ${ }^{31}$ dedicou sua coletânea de 1753 "não ao peso da erudição, mas à ciência da alegria e do prazer" (KRAUSE apud PARSON, 2004, p.61), esse seria o antídoto adequado ao supérfluo da ópera italiana que predominava dentre as classes abastadas.

No último quarto do século XVIII, o Lied continuou muito próximo a essas ideias, embora as partes de teclado tenham se tornado mais ativas e os modelos formais mais ousados. É por essa razão que alguns autores preferem definir o nascimento do gênero nessa época.

Focaremos nossa atenção nos principais compositores do século XVIII. Muitas das características citadas anteriormente ${ }^{32}$ eram discutidas no prefácio das suas obras, que continuam esquecidas pelos intérpretes.

\footnotetext{
${ }^{31} \mathrm{Em}$ momento algum Krause em seu tratado refere-se ao Lied, como tem sido afirmado, com o dever de aspirar ao folklike (Volkstümlich). Os termos que ele usou são Natürlich ou Einfältig (natural ou ingênua).

${ }^{32} \mathrm{O}$ pensamento predominante entre poetas e músicos em 1750 sobre a relação entre texto e música mantinha a música reduzida a uma linha vocal não ornamentada, geralmente sem
} 
O compositor Abraham Peter Schulz (1747-1800) viveu no período em que a poesia alemã ressurgia na era clássica após um período de adormecimento. No prefácio da edição de sua coleção de Lieder intitulada Lieder im Volkston, publicada no ano de 1782 em Berlim, discute sua concepção em relação ao texto e à música. Afirma que a música não poderia desviar-se do texto e a melodia deveria adequar-se a declamação e a métrica das palavras. Em sua concepção, a utilização de artifícios - ornamentações, repetições, interlúdios - que conduzem a atenção do ouvinte para a música deveria ser rejeitada, pois trazia danos aos Lieder.

Os compositores desse período estavam habituados a escrever óperas ou Singspiele e importavam os dispositivos composicionais dessas formas para os Lieder, buscavam o que seria o ponto de equilíbrio entre palavras e música. Reichardt e Zelter foram os primeiros compositores a encontrarem um equilíbrio entre poesia e música, em meados do século XVIII, e são os responsáveis por modificações importantes nesse gênero.

Johann Friederich Reichardt (1752-1814) foi o primeiro a musicar os poemas de Wolfgang von Goethe (1749-1832), 116 de suas 150 peças utilizam a poesia do escritor. Desenvolveu linhas vocais, efeitos harmônicos e acompanhamentos de piano que fugiam das premissas deste gênero nesse período. Foi muito original no seu Deklamation Stücke ao criar uma linha musical declamada, na qual sua preocupação estava na resolução dos problemas do ajuste musical aos padrões da prosódia alemã. Em suas peças encontramos recursos que serão explorados na próxima fase do Lied, entre eles: picos de altura para enfatizar uma sílaba; intervalos de mais difícil entoação; mudanças rítmicas; utilização de modulações, consideradas abruptas para os padrões de sua época no intuito de reforçar o significado do texto.

Karl Friederich Zelter (1758-1832) escreveu aproximadamente 400 Lieder, cerca de 200 foram publicados e 75 têm poesia de Goethe, amigo com o qual mantinha correspondência. Em uma dessas cartas, datada de 11 de maio de 1820, Goethe afirma que:

Eu sinto que suas composições são idênticas aos meus poemas: a música simplesmente eleva os poemas, como o gás a um balão. Com outros compositores eu preciso primeiro definir como eles

acompanhamento; enquanto o poema tinha uma posição dominante, a música tinha um estilo extremamente modesto. 
entenderam o poema, e o que eles fizeram com ele (GOETHE apud STEIN, 1971, p. 41).

Goethe escreve em carta de 02 de maio de 1820:

A mais pura e mais exata pintura de música é o que você realizou; a coisa mais importante é colocar o ouvinte dentro do espírito do poema; a imaginação pode invocar as figuras de acordo com o poema, sem saber realmente como isso acontece... (GOETHE apud STEIN, 1971, p.42).

O poeta chegou a afirmar que um poema lírico não está realmente completo até ser musicado. Ele preferia composições à maneira folclórica, que não se sobrepunham a sua poesia. Entretanto, sua obra e a de seus contemporâneos inspiravam composições que ultrapassavam a simples representação dos significados superficiais das palavras. Os compositores passaram a incorporar o drama da poesia em suas músicas, que com isso assumiu a função de expressar o simbolismo implícito, tão importante para a poesia romântica.

Os grandes compositores da segunda metade do século - Christoph Willibald Glück (1714-1787), Joseph Haydn (1732-1827) e Wolfgang Amadeus Mozart (17561791) - tinham um interesse periférico no Lied. Dentre eles merece maior destaque Glück, cujas contribuições para o desenvolvimento desse gênero são importantíssimas, apesar de seus Lieder não serem interpretados frequentemente.

Glück foi um dos primeiros compositores a escrever Lieder mais refinados, mesmo estando bastante habituado a escrever óperas e ballet. Partilhava do mesmo ideal de Schulz, como pode ser verificado no prefácio de sua ópera Alceste, onde afirmou que gostaria de trazer à música a sua verdadeira função, deixando de lado o excesso de ornamentos e retomando a beleza da simplicidade, evitando escrever passagens cuja dificuldade comprometesse a clareza. Glück importava procedimentos operísticos com certa moderação e com algum constrangimento. Suas composições recebiam a aprovação de Goethe, autor dos textos que ele musicava com frequência.

A coletânea de Lieder de Carl Philipp Emanuel Bach (1714-1788), com poesia de Gellert, é um marco para o gênero Lied em Berlim, pois a coleção foi um imenso e inesperado sucesso de público. A partir de uma perspectiva mais tardia, os Lieder Gellert confirmam que a liberdade musical associada a Schubert ou a Beethoven 
apareceu muito cedo na história do Lied, e por um compositor que não pode ser acusado de falta de gosto ou consciência poética. C. P. E. Bach estabeleceu o Lied como um desafio digno dos compositores em vários níveis: como um teste no poder de contenção formal, ou na versatilidade de traçar diferentes tipos de detalhes expressivos.

Viena tinha uma cultura artística muito diferente dos círculos de C. P. E. Bach em Berlim ou Hamburg. Em particular, a capital austríaca esteve sujeita à censura rigorosa do Estado até 1780. O gosto literário estava mantido na condição de uma infância relativa, a poesia Anacreôntica, vigente nos primeiros anos de C. P. E. Bach, continuava na Viena nos anos de 1780.

Haydn publicou seus dois volumes de Lieder em 1781 e 1782. Apesar de toda sua música instrumental no estilo popular, o compositor parece não responder prontamente ao imediatismo simples da linha alemã. Sem inclinação para esse material poético, parece ter faltado terreno para sua invenção musical, uma vez que não chegou ao ponto de tratar o Lied como o sumário de uma visão inteiramente emocional do mundo. Apesar disso, a importância de suas coletâneas não deve ser ignorada, principalmente pela preocupação que demonstra em relação ao tratamento motívico e a maneira que podem ser moldadas para encontrar a firmeza da forma e do conteúdo de um poema.

Em suas composições é possível perceber que sua preocupação não era a essência do poema:

Provavelmente ele não tinha o interesse de aumentar sua fama através de seus Lieder, seu objetivo era criar prazer para certa classe de amadores. Ninguém duvida de que ele poderia ter composto Lieder mais elaborados, se assim o desejasse (PARSON, 2004, p.61)

Dentre os compositores citados até o momento, os Lieder de Mozart são os mais interpretados em recitais até hoje. Geralmente os textos escolhidos por ele são pueris. Sua reputação como compositor de Lied é maior do que a de Haydn, e alguns de seus Lieder alcançaram inovações importantes.

Seus Lieder não demonstram uma intenção clara no sentido de elevar o nível desse gênero vienense. Seus três Lieder mais famosos são: Das Veilchen K476, Das Lied der Trennung K519 e Abendempfindung K 523, peças que adquirem um nível de significância completamente novo. Mozart desenvolveu uma abordagem 
musical diferenciada durante o desenvolvimento de cada uma dessas peças. Ele brincou com as expectativas líricas do gênero como parte de sua interpretação poética. Os poemas escolhidos nas composições referidas prefiguram aspectos do individualismo romântico. A música é variada, mas ao mesmo tempo unificada - em resposta ao espírito poético - pelo uso de recitativos vocais e simbolismos no teclado. Estes Lieder foram publicados em 1789 em Viena, portanto estavam disponíveis para Schubert.

Ludwig van Beethoven (1770 - 1827) é sempre a figura de transição para o romantismo. Suas contribuições são maiores em outros gêneros, mas também participou de maneira significativa no Lied, podendo ser considerado o criador do Lied Romântico. Embora suas peças permaneçam na tradição do simples reforço das palavras, seu potencial inventivo restabelece o equilíbrio, tanto pelos detalhes de sua escrita ilustrativa (por exemplo: não apenas canções de pássaros, mas rouxinóis, cotovias, pombas e condores) como pela variedade e imaginação de equivalência de seus conceitos musicais. Um bom exemplo é o ciclo An die ferne Geliebte op.98, no qual certos elementos musicais como melodia folclórica, harmonia, forma, variação e unidade cíclica são usados como dispositivos expressivos.

Para Beethoven o Lied era uma estrutura musical contínua, frequentemente sobreposta a um poema estrófico. Para seu contemporâneo Weber, a forma e a declamação eram derivadas do poema, fazendo com que a música renunciasse a sua autonomia.

As composições de Beethoven muitas vezes desagradavam aos poetas. Goethe, por exemplo, não aprovava a composição com sua poesia Kennst Du das Land. Ele acreditava que Beethoven não tinha entendido corretamente sua poesia, pois esperava que esse poema fosse musicado como uma simples canção.

Beethoven é o responsável por uma inovação muito importante, foi o primeiro a escrever um ciclo de Lieder. An die ferne Geliebte. Essa inovação foi bem explorada pelos compositores do século XIX.

Franz Schubert (1797-1828) iniciou uma nova etapa para o Lied. Alterou o caráter do gênero mais do que qualquer outro compositor e suas modificações foram desenvolvidas e aprofundadas, perdurando todo o século XIX. Transformou o Lied em um veículo de expressividade musical sem precedentes, sendo o primeiro a mudar a relação poema e música, tornando-a mais crítica. O poema perdeu um 
pouco de seu domínio, e a música desenvolveu recursos mais precisos e poderosos de estender as ideias poéticas em sua esfera abstrata. Em suas composições, como nas da maioria de seus sucessores, a música tem um caráter dominante. Isso não significa que a poesia tenha um papel menor, mas sim um papel primário; a música passa a ser a interpretação pessoal do compositor para a poesia.

No Lied anterior a Schubert, raramente a textura musical é tão rica como a poética. De Schubert em diante, o ouvinte que pretende escutar o Lied como a síntese de poesia e música precisa superar algumas dificuldades, deve ter primeiramente um texto impresso para entender realmente a poesia, que em função da complexidade musical torna-se de mais difícil entendimento.

\subsection{O LIED ROMÂNTICO: PANORAMA POÉTICO}

\subsubsection{Histórico}

O período denominado Romantismo teve seu início próximo à transição para o século XIX, época da Revolução Francesa (1789-1799). Abrangeu aproximadamente 30 anos, mas o impacto desse movimento perdurou durante todo o século XIX. Surgiu como reação ao pensamento lluminista, dentre suas premissas estão: a defesa da liberdade moral - presente no respeito pelos marginalizados que surgiam das regras impostas pela sociedade; a liberdade política - presente no sistema liberal e na implantação dos direitos humanos; e a liberdade artística.

A oposição ao lluminismo começou com o movimento transitório denominado Sturm und Drang, caracterizado pelo aumento da emotividade e cujas primeiras manifestações apareceram na poesia.

J. G. Herder e outros escritores alemães inauguraram o movimento transitório Sturm und Drang com a intenção de afirmar a primazia dos sentimentos e da intuição sobre a razão. O interesse na cultura folclórica também começou nesse período, e as primeiras manifestações foram sentidas no campo da poesia. Os poetas começaram a combater as convenções poéticas de meados do século XVIII, nas quais requinte e elegância eram considerados os elementos principais. Tornou- 
se menos importante a observação das regras clássicas de escrita, passando a ser crucial revelar a originalidade e genialidade dizendo algo profundo e significativo. $O$ conteúdo tomou precedência sobre a forma. Muitos escritores tiveram ao menos uma participação nesse movimento, entre eles: Friedrich Schiller (1759-1805) ${ }^{33}$ (1759-1805) e Johann Wolfgang von Goethe (1749-1832) ${ }^{34}$.

O Romantismo alemão é uma continuação ou desenvolvimento do Sturm und Drang, no qual o foco principal está na vida interior dos personagens, seus deslizes, conflitos internos e paixões ambíguas. O Romantismo foi um período de intenso sentimentalismo, introspecção e autoabsorção. Os poetas românticos celebraram o individual e exploraram todas as emoções humanas, desde o êxtase de alegria até o desespero devastador.

No romantismo musical, a situação social era ideal para o desenvolvimento do gênero Lied. Na crescente classe média a mulher, ao invés de trabalhar, despendia seu tempo dedicando-se a atividades culturais e cuidando da família. Essa mesma classe tinha dinheiro para comprar partituras, periódicos musicais ${ }^{35}$ e instrumentos musicais como piano e harpa. Existia a cultura e o prazer em aprender a tocar um instrumento. Saber tocar, cantar ou desenhar eram habilidades importantes para se conseguir um bom casamento ${ }^{36}$.

\footnotetext{
${ }^{33}$ Friedrich Schiller morou em Weimar nos últimos anos de sua vida. Era portador de um espírito rebelde, talvez em função das injustiças pelas quais passou em sua juventude, quando foi obrigado a frequentar a escola militar e a preparação para a carreira de cirurgião regimental.

34 A fama de Goethe estabeleceu-se em 1774 com sua Sturm und Drang novela: Die Leiden des jungen Werthers. Essa novela destaca a natureza do movimento Sturm und Drang e estimula a juventude europeia a imitar o caráter de Werther, a emotividade e também o suicídio causado por um amor não concretizado. A vida confortável que Goethe desfrutava em meio à aristocracia foi suficiente para amenizar qualquer sentimento de fervor revolucionário, pois gostava de sua prosperidade econômica e de sua posição privilegiada. Ele foi o segundo poeta em número de poemas musicados, ficando atrás apenas de Heine, que é de uma geração posterior a dele. A poesia de Goethe foi preenchida com música e inspirou um novo tipo de música. A natureza subjetiva de sua poesia, juntamente com a fluidez e a beleza lírica transformaram-se na alma do Lied.

${ }^{35}$ No século XIX, os compositores começam a escrever sobre música; podemos afirmar que a musicologia começa nesse período. A crítica musical se estabelece e passa a influenciar o cenário musical, artigos publicados em revistas musicais ajudaram a difundir a obra de jovens compositores como Chopin e Brahms, por exemplo. Schumann, Berlioz e Hugo Wolf eram críticos musicais. Liszt, Chopin e Robert Franz escreveram autobiografias. Era uma prática frequente escrever diários e manter uma correspondência volumosa.

${ }^{36}$ As mulheres deveriam ter essa cultura, entretanto não lhes era dada a oportunidade de se profissionalizar em uma carreira artística, esse conhecimento deveria ser apenas um ornamento para uma mulher verdadeiramente feminina.
} 
Nos primeiros estágios de seu desenvolvimento a performance do Lied era realizada em casa por amadores. Compositores como Reichardt e Zelter escreviam suas composições com modestos intervalos vocais e acompanhamentos simples, que se encaixavam bem nas capacidades dos amadores. No entanto, quando o Lied ficou mais sofisticado e complexo, os compositores necessitaram de instrumentistas e cantores com habilidades musicais mais desenvolvidas. Precisavam de cantores com domínio e beleza vocal, e principalmente com a capacidade necessária para entender a poesia e a habilidade técnica para transmitir nuances delicadas de som. Quando a performance do Lieder saiu das casas para as salas de concerto, os compositores conquistaram a liberdade de escrever a parte do piano utilizando os crescimento da flexibilidade técnica do instrumento ${ }^{37}$ e o furor do crescente número de pianistas virtuosos. A função do piano é expandida, passando a ser um parceiro da voz.

O patrocínio da música passou da aristocracia para o público em geral. Os compositores deixaram de ser empregados das famílias aristocratas que lhes supriam as necessidades básicas, mas que em contrapartida definiam o tipo de arte a ser escrita. Consequentemente, os músicos românticos viviam em condições precárias, e foram obrigados a apelar para o grande público, cujo gosto musical era imaturo ou desconhecido. Portanto, nesse momento histórico, as demonstrações de virtuosismo faziam muito sucesso, as façanhas surpreendentes dos virtuoses entretinham e prendiam a atenção do público não especializado. Alguns compositores possuíam habilidade virtuosística e magnetismo pessoal, permitindo que eles mesmos tocassem suas obras. Tal situação não acontecia com Schubert e Schumann $^{38}$, que dependiam do interesse e simpatia de artistas renomados para levar seus trabalhos ao público em geral.

Até o final do século XVIII, os alemães eram dispersos e desunidos, tinham pequeno senso acerca de sua identidade. Na primeira metade desse século, a

\footnotetext{
${ }^{37}$ Nesse período os instrumentos de teclado tiveram grande desenvolvimento tecnológico, que obrigou os seus intérpretes a adequarem a técnica pianística aos novos recursos por eles proporcionados.

38 Schumann perdera a movimentação de um dos dedos da mão direita, por isso via-se impedido de tocar suas composições. As primeiras audições de suas obras eram feitas por Clara Schumann. Após a morte de Robert, Clara fez exaustivas turnês para divulgar a obra de seu marido, que muitas vezes era ousada demais para o público desse século.
} 
cultura francesa era admirada em muitas partes do continente Europeu ${ }^{39}$ e muitos intelectuais de língua alemã consideravam seu idioma natal rude e grosseiro.

O novo século começou com tumultos e mudanças em toda a Europa, reflexos da Revolução Francesa. Na França, o caos da revolução deixou a nação vulnerável e sob o controle de um ditador - Napoleão Bonaparte assumiu o poder absoluto menos de dez anos após a revolução. A aristocracia europeia assistiu a revolta da classe média; a busca pelo direito de liberdade individual crescia cada vez mais.

Quando Napoleão assumiu o poder, seu brilhantismo como líder político e suas táticas militares cegaram não apenas seus conterrâneos, mas também estrangeiros como Goethe e Beethoven ${ }^{40}$. Eles ingenuamente acreditavam que Napoleão defenderia os direitos dos homens e os libertaria dos opressores da Europa. A admiração foi desaparecendo conforme Napoleão dominava estado após estado. Ficava claro que o maior interesse dele era o poder.

Depois de expandir seu império e dominar grande parte do território europeu, Napoleão obrigava todos a participarem de um tipo de sistema onde prevaleciam os interesses franceses, momento em que os vários povos europeus começaram a ressentir-se do crescimento da França e os sentimentos de identidade nacional foram amadurecendo.

O profundo nacionalismo ${ }^{41}$ é uma das características do Romantismo que faz com que os artistas direcionem seus interesses e estudos às tradições, à arte popular, às línguas vernáculas e à literatura medieval. Podemos afirmar que Napoleão transformou-se em um catalisador para a enorme quantidade de movimentos nacionalistas.

O sentimento nacionalista entre os falantes da língua alemã levou-os a se interessarem pela poesia e música folclórica, pelos mitos e pela sua história. Os músicos redescobriram Bach e suas técnicas musicais foram estudadas.

\footnotetext{
${ }^{39}$ A corte Russa falava o idioma francês e imitava os modos franceses.

${ }^{40}$ A terceira sinfonia de Beethoven - conhecida como Heróica - era dedicada inicialmente a Napoleão.

${ }^{41} \mathrm{O}$ nacionalismo demorou a se manifestar nas salas de concertos, as árias Italianas continuavam a ser características dos programas de concerto alemães. O Lied alemão era raramente executado em salas de concertos, suas apresentações eram sempre nas residências até 1830. O público alemão continuava preferindo óperas Italianas e Francesas no início do século XIX.
} 
Compositores como Schumann e Brahms ${ }^{42}$, por exemplo, exploraram as possibilidades do contraponto tradicional em seus Lieder $^{43}$.

No final do século XVIII, os alemães contavam com a presença em seu meio de eminentes figuras da literatura, teatro, filosofia, música e teologia tais como: Goethe, Schiller, Kant, Hegel, Beethoven, entre outros. E surpreendentemente a pequena corte de Weimar atraíra alguns desses ilustres: Goethe, Schiller e Herder.

Em meados do século XVIII os falantes da língua alemã começaram a vivenciar um renascimento literário e filosófico, distanciando-se gradativamente da sufocante imitação dos modelos literários franceses e direcionando o interesse para as obras de Shakespeare, Grécia Clássica, Roma e também para suas heranças particulares. Os românticos encontraram novos temas e imagens na tradução de literaturas de distintos períodos históricos, e também no uso de elementos da antiguidade e da Idade Média, esses novos materiais se converteram em um rico recurso poético.

O vínculo do idioma em comum transformou-se no elo dos trabalhos de escritores como Johann Gottfried Herder (1744-1803) e Johann Gottlieb Fichte (1762-1814). Herder defendia que os falantes da língua alemã tinham um espírito em comum, diferente de qualquer outro povo. Acreditava que cada grupo falante de um idioma em comum, dividia o mesmo ideal e evidenciava um espírito definido por ele como Volksgeist (espírito do povo), que espelha sua individualidade. Para Herder, nenhuma sociedade era melhor do que outra; cada uma refletia um caráter específico, já para Fichte, os alemães eram melhores do que qualquer outro povo ${ }^{44}$.

O termo Volkslied foi cunhado pelo filólogo, teólogo e poeta tradutor Herder, que catalogou a poesia folclórica dos falantes da língua alemã e também algumas poesias de outros países que ele mesmo traduzia, publicando dois volumes intitulados Volkslieder, em 1778-79. Algum tempo depois, teóricos românticos como

\footnotetext{
42 Os Lieder de Brahms são extremamente influenciados pelo folclore, ele coletava e arranjava tanto melodias como poemas folclóricos. O folclore também foi fonte de inspiração para Mahler na segunda metade daquele século.

${ }^{43} \mathrm{O}$ gênero Lied, além de estimular o desenvolvimento de outros gêneros nacionalistas de canção, como a Mélodie francesa e a Lírica da Câmara italiana, fez com que a canção passasse a ser uma forma musical de interesse dos compositores. A relação poema e música já explorada por muitos séculos ganhava nova vitalidade e, principalmente, novo vocabulário com o Lied romântico.

${ }_{44}$ Possivelmente esses pensamentos, que conduziram os artistas alemães ao desenvolvimento do gênero Lied de beleza única, quando levados ao exagero também conduziram os alemães ao auge da intolerância no nazismo.
} 
Friedrich Schlegel e os irmãos Grimm tomaram esses versos como um tipo de expressão espontânea do coletivo - Volkseele (alma do povo).

Em 1807 esses poemas ganharam uma segunda edição: Stimmen der Völker in Liedern - Vozes do povo em canções, livro que foi uma fonte importante para os compositores de Lied no século XIX. O envolvimento de Herder com a poesia folclórica alemã atraiu a atenção de figuras importantes da literatura como Goethe, que percebeu que essa excelente pesquisa encontrava lugar em cada casa alemã, refletindo o crescente nacionalismo europeu. Seu elogio à pesquisa pode ser explicado pela sua experiência, 30 anos antes, como estudante em Strasbourg coletando canções folclóricas na região rural de Alsatian, sob a tutela de seu mentor Herder. Goethe passa a escrever vários poemas à maneira folclórica.

Embora os poetas alemães tenham escrito Lieder desde muitos séculos antes de Herder, é uma peculiaridade da herança do Lied do século XIX que seu precursor presumivelmente natural, acreditando ser uma expressão espontânea do Volkseele, tenha surgido como conceito apenas para os teóricos românticos do início do século XIX. Considerando que este Lied encontrou suas origens teóricas nas reconstruções especulativas dos teóricos do período, a poesia romântica por si só retira seu ímpeto fudamental da vasta e variada obra inicial de Goethe, cujo lirismo inspirado musicalmente já florescia nas três décadas anteriores a 1800.

Johann Ludwig Uhland (1787-1862) também escreveu poemas que espelham a simplicidade da poesia foclórica. Muitos de seus poemas líricos foram musicados por Brahms, Liszt, Grieg, Loewe, Mendelsohn, Hensel, Schubert, Schumann e Strauss. Uhland era ativista político além de poeta e foi membro da Assembleia de Frankfurt de 1848 que visava à criação do estado liberal alemão.

O interesse na poesia folclórica cresceu no século XIX. Achim Von Arnim (1781-1831) e Clemens Brentano (1778-1842) publicaram o primeiro volume da coleção de líricas folclóricas Des Knaben Wunderhorn. Esta coleção, completada em 1808, foi extremamente importante para os compositores de Lied.

Embora a coletânea, dedicada a Goethe, não seja sempre fiel às fontes originais - nem toda poesia é genuinamente folclórica - transformou-se no principal livro de referência para Mendelssonh, Reichardt, Schumann, Brahms, Mahler, Strauss e Schoenberg. Também elevou a moral alemã e alimentou as aspirações nacionalistas em face das conquistas de Napoleão. 
Outros estudiosos coletaram contos folclóricos e examinaram a história da linguagem alemã, entre eles Jacob Grimm (1785-1863) e seu irmão Wilhelm Grimm (1786-1859).

\subsubsection{Características do gênero poético}

O que entendemos como Lied Romântico começou com o poeta alemão Goethe $^{45}$ - profundamente importante para o Lied, pois foi o mais original, mais influente e mais representativo poeta do período em que poesia e música estavam intimamente relacionadas e expressavam as mesmas preocupações culturais.

Uma característica principal, tanto da poesia como da música, do final do século XVIII e início do XIX torna possível a fusão única que caracteriza este Lied.

O surgimento em meados do século XVIII de um novo tipo de poesia lírica, definida como Bekenntnislyrik (Poesia confessional) - versos caracterizados por uma declaração de persuasão pessoal, cuja forma não reduz a direção e a força subjetiva da mensagem, embora o poeta utilize mecanismos de expressão lírica para alcançar este efeito. Goethe foi particularmente competente nesse tipo de expressão lírica, conseguindo utilizar os mecanismos da poesia (métrica, ritmo, rima, estrofes) para criar um sentido de transcendência em um comunicado intensamente pessoal, influenciando os escritores do século XIX. Próximo ao final do século XVIII, a música desenvolveu essa mesma capacidade de superar os aspectos técnicos da expressão musical em uma poderosa comunicação subjetiva.

A linguagem musical conquistou uma habilidade na utilização de técnicas de expressão musical que criavam um estado esmagador de subjetividade, individualidade e confissão. Quando este tipo de comunicação musical foi unido ao poema lírico, de mesma natureza, e sua musicalização reforçou o estado psicológico do poema, foi encontrado um ponto culminante na estética do Lied. Esses instantes de convergência são realmente raros, mas quando acontecem representam o ápice de determinado gênero de arte.

\footnotetext{
${ }^{45}$ No início da década de 1870 ele foi considerado a figura cultural paterna dos alemães para o estabelecimento educacional do Segundo Império e foi amplamente lido nas escolas.
} 
Goethe foi o poeta mais musicado por compositores alemães no que se refere à quantidade e diversidade de poemas musicados; Heine está em segundo lugar. Goethe escreveu muito mais poesias líricas do que qualquer outro escritor antes de Rilke e a principal característica de seus versos era o tom emocional. Além de seu engajamento musical - como libretista e diretor de teatro - sua amizade e colaboração com compositores como Reichardt e Zelter, e sua crença de que a poesia deveria ser cantada, são razões para o seu domínio.

A poesia romântica desenvolveu-se em duas direções, passando a ser heróica e vulnerável; solitária bem como aspirando ao universal; grandiosa e ao mesmo tempo intimista. Estas características aceleraram o desenvolvimento do Lied, inicialmente algo pequeno e caseiro que gradualmente adquiriu um poder expressivo desproporcional ao seu tamanho. O Lied assumiu uma qualidade atemporal, aparentemente contém traços do passado e do presente, bem como aponta para o futuro.

Encontramos no Lied tanto a poesia narrativa quanto a lírica. Na narrativa, o poema é tratado como um relato, geralmente o poeta busca a ambientação medieval, dando preferência ao lúgubre, e têm suas bases nos romanceiros e nas lendas de tradição oral. A matéria-prima dessa poesia está nos acontecimentos da vida, nas guerras e nos feitos heroicos.

A poesia lírica é uma forma poética nascida na Grécia Antiga. Era geralmente acompanhada pela flauta ou pela lira, daí a origem do nome. Nasceu da fusão com a épica, e no decorrer de sua história sofreu várias transformações que resultaram no surgimento de estilos como a ode, a elegia, os epitáfios, as canções, as baladas, entre outros. Neste gênero, o poeta se dirige diretamente ao leitor a fim de expressar os seus mais profundos sentimentos. Ela é geralmente cantada e acompanhada de música, e permite que o poeta liberte os sentimentos encobertos no poema épico.

Esta forma poética foi escolhida pelos compositores de Lied, por se tratar de uma estrutura com forte preocupação em libertar os sentimentos. A lírica romântica é um reflexo da literatura da época, onde os temas principais são a reivindicação da liberdade, a subjetividade, a exaltação do eu e o desejo de realização do indivíduo em uma sociedade não burguesa - o que leva ao maior desprezo das normas, do dinheiro e da vida, e, consequentemente, a ser mais generoso.

A grande quantidade e a exuberância da poesia lírica foram cruciais para o desenvolvimento do Lied no período romântico, já que atendia a necessidade do 
compositor de refletir seus sentimentos íntimos em uma composição que mesclava palavras e música.

A poesia alemã encontrou natural contrapartida na cada vez mais sofisticada linguagem musical disponível para os compositores contemporâneos que falavam alemão ${ }^{46}$.

As letras românticas adaptavam-se à expressão das aspirações nacional e social, bem como aos temas tradicionais dos versos seculares ou profanos. Isso era um atrativo para sua rápida expansão nas classes cultas, alvo dos jornais culturais ou almanaques onde a nova poesia era publicada. A classe média estava bem posicionada para apreciar não somente o novo conteúdo pessoal e emocional dessa poesia, mas também a mistura estilística do estilo polido elevado com a lírica popular.

Todos os temas da literatura romântica estão presentes no Lied. O artista como um Wanderer ${ }^{47}$ expulso da sociedade, o deleite com a natureza, o amor ao passado e ao exótico (incluindo os Gregos, Romanos, Persas e a Idade Média), as forças sobrenaturais, fantasmas, fadas e principalmente o amor, que é o tema mais popular.

Os escritores do período em questão, numa busca insaciável, queriam ir além do que já era conhecido, refletindo o anseio romântico resultante das limitações impostas pelo lluminismo. Os artistas desejavam eliminar fronteiras, ultrapassar limites, desfrutar do infinito. Isso resulta no desejo de escapar do cotidiano mundano através de intoxicações, da exploração do místico e também da investigação do anormal. O poeta romântico nos transporta a terras imaginárias, geralmente desconhecidas, vagas e sombrias. A ânsia pelo desconhecido aparece na poesia com diferentes facetas: no misticismo da crença religiosa, na escuridão da noite e na atmosfera amorfa do mundo dos sonhos.

\footnotetext{
${ }^{46}$ Esse mesmo fenômeno não aconteceu na Inglaterra, por exemplo.

${ }^{47} \mathrm{~A}$ imagem que melhor simboliza a preocupação romântica com o tema da individualidade no mundo das emoções é a figura do Wanderer - uma figura solitária cujas viagens através do mundo refletem uma similar jornada espiritual ao seu interior. Esse protagonista romântico meditou, comungou com a natureza e falou com Deus; experimentou a ansiedade romântica com sensibilidade requintada. $O$ Wanderer incorpora dois outros elementos do romantismo alemão: o interesse pelas pessoas comuns, e a crença de que a situação da existência cotidiana, com a onipresente dificuldade do amor, foi mais bem expressa pelo artista. Essa imagem incorporou o paradoxo romântico da necessidade humana de conforto tanto do amado como da família, que é transitória e imprevisível, como também, ao mesmo tempo, a busca de libertar-se das fraquezas da interação humana através da solidão da natureza ou através da libertação da morte.
} 
Baseados nos conceitos expostos podemos afirmar que esta poesia é marcada pela celebração do contraditório ou dicotômico ${ }^{48}$, a mistura de dois elementos aparentemente incompatíveis ou opostos em uma mesma entidade, reação a racionalidade e ordem extremamente opressivas. Os românticos buscavam definir o mundo através de opostos e paradoxos: intensificavam a realidade com a imaginação, enfatizavam o espiritual contrastando-o com o material, o visível era contrastado com o invisível e o tangível com o intangível.

A consequência direta da reação contra a ordem do lluminismo era o gosto pelo caos, obscuridade e ambiguidade. A fusão de elementos contraditórios criou confusão, desnorteamento e ambiguidades de tempo, espaço e persona. $\mathrm{O}$ instinto colidia com a razão; a tortura do presente misturava-se com o passado feliz. Como resultado, a ausência de clareza e a multiplicidade de significados criando um rico e substancioso caos - amado pelos românticos - que os conduzia ao axioma básico do romantismo alemão: a ironia. A ironia central do período romântico era: o poeta buscava o infinito que, por definição, era inatingível ${ }^{49}$.

A literatura romântica alemã é repleta de poemas cujos títulos realçam sentimentos e estados psicológicos. Os românticos celebraram a sensualidade e exploraram as complexidades da psique através de investigações no mundo do subconsciente e dos sonhos (pesadelos ou fantasias nas quais os desejos se realizam); e também os extremos emocionais causados pelas intoxicações (usando vinho ou drogas, ou no âmbito do poder do amor e da natureza).

Assim como o mundo interior da psique humana deu ao poeta romântico uma riqueza de temas e imagens, do mesmo modo o mundo da natureza, com seus elementos diversos e forças conflitantes, forneceram ao poeta abundância de material. O mundo natural contém uma ampla gama de objetos naturais, criaturas e sons que fornecem ao poeta tanto uma atmosfera onde é possível perceber e sentir tudo vividamente, como uma paisagem na qual é possível caminhar e lutar.

Além de propiciar ao poeta uma nova fase dramática, o mundo da natureza também incorporou a luta dos românticos entre forças ambivalentes: por um lado a

${ }^{48}$ O Doppelgänger, o duplo espectral que assombrou os românticos, era a figura vívida que confrontava o poeta com o outro lado de si mesmo, desse modo o poeta era colocado dentro da dicotomia de sua alma.

${ }^{49}$ A ironia é expressa por distintas combinações de elementos contraditórios, por exemplo: ânsia romântica por um amor irrealizável; choro de alegria porque o amor é cheio de dor; a luz da lua criando sombras na paisagem. 
natureza nutre e cura com suas brisas calorosas e calmantes, por outro essa mesma natureza destrói com o frio debilitante e as tempestades ameaçadoras. O poeta, vulnerável à natureza, estava ciente dos mistérios e variabilidades dela. Muitas poesias centralizam-se nos momentos de mudança causados pelas trocas das estações do ano ou até mesmo pelas mudanças que ocorrem durante um mesmo dia.

A paisagem e a natureza deixam de ser simplesmente o ambiente onde os fatos se passam e convertem-se no espelho fiel do interior do artista. O poeta era uma pequena voz no interior de uma imensidão, às vezes avassaladora, uma presença natural que provoca tanto espanto como pavor, incluindo o sobrenatural e os recursos para a transcendência. É recorrente nesta poesia a imagem de flores e pássaros e água: córregos e riachos representam o lado confortante da natureza; os mares tempestuosos representam a natureza ameaçadora.

A tentação do mistério veio de todas as experiências românticas, do domínio psicológico interno (inconsciente e sonhos), da vastidão da natureza e do lado místico da devoção religiosa. O mundo interior do poeta era examinado através da análise dos sonhos, do estudo da loucura e do interesse pela hipnose. O mistério na natureza estava representado pelas florestas negras, pelas paisagens de luar repletas de luzes difusas e pelos sussurros da noite silenciosa. Os mistérios dentro da convicção religiosa são expressos em temor e pavor, como senso de anseios e premonições.

As reações aos mistérios da psique, ao mundo da natureza e ao espiritual são intensificadas quando chega a noite e a escuridão permite a evasão da vida diária e a intensificação do desconhecido, quando o poeta, em completa solidão, se sentia em perfeita sintonia com o mistério.

O tema do fervor religioso e da devoção, especialmente dentro do Catolicismo, permeia muitas poesias românticas alemãs. A fé religiosa estava intimamente ligada ao desejo da morte (como salvação espiritual) e foi expressa mais vigorosamente dentro do contexto da natureza. A devoção religiosa dos românticos geralmente era expressa no contexto do amor pelos mistérios; a fé religiosa incluía elementos místicos e sobrenaturais e o conceito de presença divina incluía outro mundo, além do conhecido na terra.

Outro aspecto a destacar era a preocupação com os mistérios da morte. 0 anseio pela morte estava sempre presente como solução para a inescapável dor do 
amor perdido, para os tormentos terrenos e outros problemas. Os românticos tentavam fugir das preocupações do presente através da imersão no passado, principalmente no que se refere às bases greco-romanas. Histórias gregas e romanas (heróis e histórias mitológicas) e aspectos culturais (estruturas arquitetônicas e ambiente Mediterrâneo) foram adaptados para dramatizar e descrever os temas e características românticas. 
3 PROPOSTA DE ANÁLISE 


\subsection{ENFOQUE ANALÍTICO}

Tendo em vista que o foco central deste trabalho é a realização de um estudo das características dos Lieder de Clara Schumann, acreditamos, como ponto de partida, ser necessária uma reflexão sobre o significado da palavra análise.

No dicionário Houaiss (2009) encontramos, entre outras, as seguintes definições para o termo análise:

1 separação de um todo em seus elementos ou partes componentes;

2 estudo pormenorizado de cada parte de um todo, para conhecer melhor sua natureza, suas funções, relações, causas etc.;

3 exame, processo ou método com que se descreve, caracteriza e compreende algo (um texto, uma obra de arte etc.), para proporcionar uma avaliação crítica do mesmo.

De acordo com as definições expostas, pensaremos a respeito desse termo em nosso estudo musical.

Em música existem várias possibilidades de enfoque analítico. A escolha depende, exclusivamente, do objetivo que se pretende atingir. É fundamental estar ciente da meta buscada no processo de análise, pois só a partir disso é possível definir qual será o melhor direcionamento para a realização de um estudo eficiente. Os diversos usos desta ferramenta, em uma mesma obra, podem produzir diferentes resultados, que não serão necessariamente excludentes. Nesta pesquisa, criaremos um modelo de análise que compreenderá o exame da obra como um todo: poesia e forma musical; linha melódica vocal; acompanhamento pianístico; e definições subjetivas.

A importância de estudos como o que estamos propondo, vem da necessidade de evitar vícios culturais, frutos da carência de informação, presentes na performance de intérpretes de Lieder. Assim, é preciso enfatizar que o Lied Romântico é uma manifestação artística genuinamente alemã, que apresenta características intrínsecas a esta cultura.

Desta forma, para melhor entendimento do Lied é de extrema importância refletir sobre determinadas convenções culturais alemãs que aparecem nas obras 
estudadas e devem ser captadas pelo intérprete para que este, durante a sua performance, não as desconsidere e acabe por interferir inadequadamente na obra.

\subsection{ANÁLISE POÉTICA E FORMA MUSICAL}

O Lied é uma forma de arte resultante da síntese de duas linguagens; sua essência é a fusão entre música e texto. Portanto, para entendermos como a música relata o poema temos de entender as duas linguagens de forma isolada, para posteriormente traçar associações.

Nosso primeiro olhar na poesia será com o intuito de identificar os recursos estilísticos, a métrica, o esquema de rimas e as figuras de linguagem. Para a elucidação de alguns termos utilizados na análise poética, utilizamos as palavras de Bechara (2001, p. 628):

Em sentido formal chama-se de poesia à forma de expressão ordenada segundo certas regras e dividida em unidades rítmicas.

O Verso é o conjunto de palavras que formam, dentro de qualquer número de sílabas, uma unidade fônica sujeita a um determinado ritmo.

O Ritmo é a divisão do tempo em períodos uniformes mediante os apoios sucessivos da intensidade.

E o Metro é o verso que, além de atender ao ritmo, se apresenta dentro de uma norma regular de medida silábica.

A métrica poética engloba tanto a alternância entre sílabas acentuadas e não acentuadas como o tamanho da linha poética, ou seja, a quantidade de sílabas em cada linha do poema. Ambas as características podem ser regulares ou irregulares. A métrica poética não é necessariamente igual à métrica musical. $O$ padrão de sílabas acentuadas e não acentuadas normalmente não forma pulsos regulares como os da métrica musical. Podemos entender que uma composição musical é uma possibilidade de leitura de um determinado poema, e sabemos que existe uma grande variante de possibilidades de leitura. Portanto, podemos dizer que a escolha da acentuação pode ser uma opção interpretativa.

O Lied no século XIX apresenta uma série de características rítmicas. Os poemas geralmente seguem uma acentuação silábica, ou seja, alternam um padrão 
de sílabas acentuadas e não acentuadas. As linhas poéticas tendem a ser pequenas, compreendendo três ou quatro sílabas acentuadas por linha.

Para a definição de rima, nos parece mais apropriado recorrer novamente às palavras de Bechara (2001, p. 640):

\begin{abstract}
Chama-se rima a igualdade ou semelhança de sons pertencentes ao fim das palavras, a partir da sua última vogal tônica. As palavras em rima podem estar no fim (rima final, a mais usual) ou no interior do verso (rima interna). Interna é a rima que se faz com a última palavra de um verso e uma no interior do verso seguinte.
\end{abstract}

Quanto à maneira pela qual se dispõem nos versos, as rimas de finais de frase podem ser: emparelhadas - aabbcc, alternadas ou cruzadas - abab, opostas (ou entrelaçadas ou enlaçadas) - abba, interpoladas - aabccb, e misturadas - são aquelas em que a distribuição é livre.

A aliteração (o apoio rítmico que consiste em repetir fonemas em palavras simetricamente dispostas) e a assonância (rima imperfeita, em que há apenas identidade nas vogais tônicas, o mesmo que rima toante) precisam ser observadas, pois contribuem com o ritmo e a sonoridade da poesia (BECHARA, 2001, p.643).

O entendimento das figuras de linguagem é necessário para que o sentido real da poesia seja captado, muitas vezes a essência poética não é apresentada de maneira explícita, mas através de metáforas, trocadilhos e ironia, exigindo maior acuidade do leitor.

O significado do poema deriva da escolha e do tipo de combinação das palavras. Segundo Bechara (2001, p. 397):

No decorrer de sua história nem sempre a palavra guarda seu significado etimológico, isto é, originário. Por motivos variadíssimos, ultrapassa os limites de sua primitiva 'esfera semântica' e assume valores novos... A significação das palavras está intimamente relacionada com o mundo das idéias e dos sentimentos.

O uso de diferentes dispositivos poéticos concede às palavras maior riqueza. Para tanto, dentre os recursos utilizados pelos poetas estão a retórica ${ }^{50}$, arte de usar palavras para influenciar ou persuadir, e as figuras de linguagem, de pensamento e

\footnotetext{
${ }^{50}$ Retórica é a arte de bem falar; conjunto de regras relativas à eloquência que, por sua vez, é a faculdade de falar de modo que se consegue dominar o ânimo de quem ouve; talento de convencer, deleitar ou comover.
} 
de palavras que podem ser entendidas como recursos estilísticos com os quais se embeleza, enfatiza, ou se dá mais originalidade à expressão das ideias. Tais recursos podem consistir na mudança do sentido das palavras, na estruturação da frase, nas sutilezas e no parentesco das ideias.

A análise das figuras de linguagem ou de retórica pode nos revelar também características sonoras da poesia. Para entender as figuras de linguagem geralmente utilizadas, mais uma vez utilizaremos as definições encontradas no dicionário Houaiss (2009):

Metáfora: designação de um objeto ou qualidade mediante uma palavra que designa outro objeto ou qualidade que tem com 0 primeiro uma relação de semelhança.

Símile: figura que estabelece uma comparação entre dois termos de sentidos diferentes ligados pela palavra como ou por um sinônimo desta (qual, assim como, do mesmo modo que etc.); ambos estão obrigatoriamente presentes na frase e um deles, com sentido real, identifica-se com outro mais expressivo; comparação assimilativa.

Símbolo: signo que apresenta relação arbitrária, baseada apenas em convenção, com o objeto ou a idéia que representa; redução fixada por convenção de valor geralmente internacional.

Trocadilho: jogo de palavras que apresentam sons semelhantes ou iguais, mas que possuem significados diferentes, de que resultam equívocos por vezes engraçados; uso de expressão que dá margem a diversas interpretações.

Personificação: ato ou efeito de personificar; indivíduo que representa, simboliza ou faz lembrar alguma coisa abstrata; indivíduo que personifica ou representa uma qualidade, uma ideia etc.

Ironia: figura por meio da qual se diz o contrário do que se quer dar a entender; uso de palavra ou frase de sentido diverso ou oposto ao que deveria ser empregado para definir ou denominar algo.

Isto posto, verificaremos como os aspectos da poesia foram compreendidos e interpretados pelo compositor. Aqui teremos a possibilidade de verificar se o compositor foi fiel ao sentido da poesia ou se reinterpretou ou atribuiu novos significados a ela. Primeiramente será observado qual foi a forma musical ${ }^{51}$ escolhida pelo compositor, verificando se ela é coerente com a forma do poema.

${ }^{51}$ O termo forma é utilizado em muitas acepções nas expressões 'forma binária', 'forma ternária' ou 'forma rondó', ele se refere, substancialmente, ao número de partes (a palavra partes é utilizada para indicar elementos indiferenciados, seções ou subdivisões). Em um sentido estético, o termo forma significa que a peça é 'organizada', isto é, que ela está constituída de elementos que funcionam tal como um organismo vivo. Sem organização, a música seria uma massa amorfa, tão ininteligível quanto um ensaio sem pontuação, ou tão desconexa quanto um diálogo que saltasse despropositadamente de um argumento a outro (SCHOENBERG, 2001, p.27). 
No Lied, as formas mais usadas pelos compositores são: forma estrófica, forma binária, forma ternária, forma rondó e a forma singular.

\section{Forma estrófica}

Nessa forma temos uma primeira estrofe musicada, e a repetição dessa mesma parte musical em todas as estrofes do poema. À primeira vista parece muito simples, mas na realidade desafia o compositor, uma vez que este precisa descobrir como a repetição pode ser usada para unificar o texto, como repetir a mesma música em toda a poesia, sendo que o poema prossegue linearmente, contando uma história. Para ajudar a solucionar essas dificuldades é frequente a adição de interlúdios entre as estrofes e também o acréscimo de poslúdio.

A forma estrófica pode ser dividida em simples ou modificada. Na simples, todos os versos têm o mesmo número de sílabas, e essa é uma condição para que uma mesma melodia seja utilizada em todos os versos. Se tivermos variações no número de sílabas o compositor é obrigado a fazer alterações musicais.

A modificada, como o próprio nome diz, envolve o uso de alguma modificação ou variação dentro da forma estrófica simples. Nela o compositor preserva a repetição estrófica, mas adiciona mudanças entre os versos para ajustar a melodia às mudanças de quantidades de sílabas. Essa alteração pode aparecer em apenas um dos versos.

Ao interpretar um Lied estrófico o intérprete deve estar ciente do motivo pelo qual essa forma foi escolhida. É importante pensar que implicações as repetições trazem para a performance, de que maneira o material musical precisa ser reinterpretado em cada reaparição para que o significado do texto seja compreendido e o interesse seja mantido na estrofe musical repetida.

O intérprete precisa encontrar o significado e a $\operatorname{cor}^{52}$ de cada palavra do texto. É necessário adotar um critério para defini-los e identificar o que é essencial para transmitir o significado do texto. As variações de dinâmica entre as estrofes e a ênfase diferenciada na repetição de palavras são recursos que podem ser utilizados para auxiliar na descrição do poema.

\footnotetext{
${ }^{52}$ As diferentes combinações de parâmetros como: modo de articulação, intensidade e timbre produzem distintas sonoridades que aqui chamamos de cor.
} 


\section{Forma ternária $\mathrm{ABA}$}

Essa forma também se vale de repetição. Temos a apresentação de um material melódico na seção $A$. Na seção $B$ temos geralmente um material contrastante e para encerrar uma repetição da seção $A$, que pode ser variada A'.

Nessa forma temos algumas alterações frequentes que acontecem em função da poesia. Uma possibilidade é a repetição da seção $A$ antes da apresentação da seção $B$. Temos, portanto, um AABA ou AABA'. Outra possibilidade é a ampliação da parte contrastante, seção $B$, e temos um ABBA ou ABB'A.

Novamente $\mathrm{o}$ intérprete deve se preocupar com a interpretação do material musical repetido. É importante lembrar que o personagem do Lied vivenciou uma série de emoções. Quando o material musical é repetido, portanto, o conteúdo emocional é diferente.

\section{Forma bipartida A/B}

Nessa forma temos a apresentação de dois materiais musicais. Outra organização formal para esses dois elementos é a também forma binária $A B A B$, que permite a oscilação entre duas seções repetidas e não depende de um retorno à seção A para encerrar. Outra possibilidade menos frequente é $A A B$, que nos mostra mais uma vez que o final pode ocorrer sem a repetição da seção $A$.

\section{Forma Rondó e refrão}

Esta é a forma em que a seção $A$ retorna significativamente depois de indefinidas seções contrastantes ABACA, por exemplo. A essência dessa forma é a repetição de uma seção - claramente identificada - que abre e fecha o trabalho, apesar de uma ou mais digressões. A variação de uso de dois ou mais elementos está fortemente associada à música instrumental.

A música recorrente na seção $A$ geralmente apresenta versos diferentes. A repetição da música associada a repetidos textos poéticos adiciona maior dimensão de reiteração. A repetição de texto e música, denominada refrão, era uma técnica caracterizada pela repetição de uma marca, utilizada pelos poetas para unificar os trabalhos mais longos. 


\section{Forma Singular}

"O termo forma singular é usado aqui como uma possível tradução para os conceitos de Durchkomponiert (em alemão) ou Through-composed (em inglês)" (SOUZA, 2010, p.39). Até agora foi possível perceber a necessidade de uma repetição formal para estabelecer a unidade (coerência e continuidade) e criar um encerramento para o Lied, mas às vezes são encontradas composições que utilizam pouco este recurso. Esses Lieder descrevem uma jornada emocional completa, onde o retorno não é possível ou necessário. Nessas peças a progressão poética adequa-se a uma forma musical cíclica e a unidade da peça se dá pela utilização de motivos repetidos, sejam eles rítmicos ou melódicos.

Após essas considerações nosso foco se dirigirá a trechos menores e passaremos a observar separadamente a linha melódica e o acompanhamento. Para que uma interpretação seja consciente se faz necessário o entendimento de todos os aspectos da obra isoladamente.

\subsection{LINHA MELÓDICA VOCAL}

A concentração da ideia principal em uma simples linha melódica requer um tipo especial de equilíbrio e organização... É difícil que uma melodia possa apresentar elementos não-melódicos, pois o que é melodioso está intimamente relacionado àquilo que pode ser cantado. A natureza e o caráter do instrumento musical mais antigo a voz - determina aquilo que pode ser entoado (SCHOENBERG, 2001, p.126).

No Lied romântico a textura da linha melódica é resultante da utilização do estilo silábico e do florido. Ambos podem ser tanto legato (notas ligadas o máximo possível) como parlato (sílabas mais desconectadas umas das outras), compreendendo todas as possibilidades de articulação.

No estilo vocal silábico se canta uma nota por sílaba, possibilitando a apresentação do texto com muita clareza e simplicidade. As notas podem ser repetidas, ou seja, muitas sílabas cantadas em uma mesma afinação ou ainda o oposto, uma linha melódica com intervalos ascendentes ou descendentes, sendo 
que os saltos podem compreender intervalos grandes ou pequenos. O estilo silábico é o oposto do estilo florido onde algumas sílabas podem ser prolongadas durante duas ou mais alturas.

Temos também o estilo recitativo, proveniente da ópera, onde o cantor tem uma considerável liberdade rítmica para cantar as palavras e as frases. Esse estilo é pouco frequente no Lied romântico.

Depois de estudado o estilo vocal, focaremos nossa atenção nas características melódicas individuais. Partiremos para a descrição detalhada dos recursos expressivos utilizados na escrita da linha melódica vocal.

Identificaremos qual a tessitura da melodia vocal, o contorno geral da linha e a localização do clímax. Observaremos se há presença de elementos cromáticos, se essa linha melódica está confinada a um único registro vocal ou se compreende diferentes registros. A linha vocal pode ser ainda mais complexa e expressiva quando se utiliza uma linha melódica composta, formada por duas partes, uma no registro agudo e outra em um registro mais grave, fazendo uma espécie de contraponto dentro de uma única linha.

Podemos encontrar algumas alturas mais importantes ou mais frequentes do que outras. É possível que algumas sejam enfatizadas por um extremo de tessitura, uma mudança repentina de dinâmica, ou ainda por uma indicação incomum de timbre.

Ao observar a linha melódica é importante identificar quais são os seus pilares, ou pontos de apoio. Depois de localizados, verificaremos se coincidem com os pontos de apoio da harmonia para definir quais são as notas estruturais e quais são as notas de passagem. No estudo anterior acerca da poesia definimos a acentuação do poema; agora vamos compará-la com a acentuação musical utilizada. A acentuação musical pode aparecer pela utilização de distintos recursos, entre eles: acentuação métrica do compasso; acento agógico (resultado de uma síncopa ou prolongamento de nota inesperado) ou um acento resultante de uma nota no extremo da tessitura.

São várias as possibilidades de acentuação musical e estas podem ou não coincidir com a acentuação verbal. Quando encontramos diferenças na acentuação é importante identificar qual é o motivo. Geralmente, o fato de se acentuar sílabas distintas provoca alguma alteração ou ênfase no sentido do texto. 
Depois de estudados estes aspectos objetivos, claramente escritos na partitura, vamos definir um aspecto subjetivo de extrema relevância à performance, a definição da persona. Chamamos de persona a pessoa que está falando o texto. Podemos ter uma única ou várias personas dentro de uma mesma poesia. Essas distintas personas podem se dirigir a diferentes audiências. Na poesia lírica o poeta pode falar tanto internamente dentro de um monólogo como externamente para outra presença, seja ela real, imaginária, ou ainda um elemento da natureza.

Em muitos Lieder a persona encontra-se explicitada no título da peça. Geralmente quando temos mais de uma persona, elas estão falando umas para as outras; quando temos apenas uma, na maioria das vezes ela está falando para alguém desconhecido. A relação entre voz e acompanhamento pode apresentar diferentes personas.

O cantor apresenta as palavras do poeta. Portanto, o intérprete precisa definir quem é esta persona e para quem ela está cantando em cada momento da peça. Importante frisar que o destinatário do poema pode mudar no decorrer da poesia.

O entendimento de para quem o cantor está cantando é fator definitivo para a dinâmica. Se o endereço é outro personagem poético ou outra persona, representada pelo acompanhamento, a linha vocal é direcionada e mais explícita. Se o texto exprime um espírito introspectivo, uma direção interiorizada, a linha vocal é mais sensível a pensamentos internos e emoções. Além de entender quem é a persona e para quem ela canta, os intérpretes devem tornar essas relações inteligíveis ao ouvinte.

Após a análise de elementos gerais da linha vocal, direcionamos nossa atenção a trechos cada vez menores - frases e motivos - em busca dos detalhes que ajudam a dar unidade à peça.

O tamanho de uma frase ${ }^{53}$ é geralmente de quatro compassos, para que se encaixe em uma única respiração. Normalmente cada frase compreende um verso

${ }^{53} \mathrm{O}$ termo frase significa, do ponto de vista da estrutura, uma unidade aproximada àquilo que se pode cantar em um fôlego. Seu final sugere uma forma de pontuação, tal como uma vírgula. Alguns elementos frequentemente aparecem mais de uma vez no âmbito de uma frase, são eles as características motívicas.

O ritmo é um elemento particularmente importante para moldar a frase: ele contribui para o seu interesse e variedade, estabelece seu caráter e é frequentemente o fator determinante para a existência de sua unidade. O final de frase é, em geral, ritmicamente diferenciado, de modo a estabelecer uma pontuação.

O acréscimo de notas, não pertencentes aos acordes, contribui para a fluência e para o interesse da frase, desde que elas não obscureçam ou contrariem a harmonia. As várias 
do poema. As frases podem ser pareadas, o que sem dúvida contribui para compreensão das rimas da poesia.

É imprescindível observar se as frases recebem algum prolongamento ou extensão em função do texto, recurso muito comum na forma estrófica modificada. $O$ intérprete deve saber se os finais de frase têm respiração ou se as frases são justapostas, de maneira que o final de uma frase é o começo da próxima.

A partir do entendimento das frases começamos a definir o andamento da peça, sabendo que este pode variar de cantor para cantor, em função da diferença de capacidade respiratória.

Seguimos em direção ao centro da ideia composicional, momento em que deixamos de observar a integridade melódica e passamos a direcionar o foco aos elementos melódicos individuais. A atenção será direcionada aos motivos ${ }^{54}$ existentes.

Os motivos melódicos compreendem uma ampla gama de possibilidades de alteração e desenvolvimento. Os motivos podem ser desenvolvidos por repetição e por variação.

Os procedimentos de repetição não alteram a estrutura do motivo, temos a repetição em diferentes situações sem perder as características originais. O motivo pode ser transposto para vários graus da escala; pode sofrer uma inversão na direção do intervalo melódico - nesse procedimento mantemos as notas, apenas mudamos a direção do salto de modo que os intervalos melódicos ascendentes se tornam descendentes e vice-versa.

As possibilidades com variação compreendem:

'formas convencionais' de resolução desses tipos de notas (notas de passagem, notas auxiliares, notas alteradas, retardos, appoggiaturas etc.) auxiliam a clareza harmônica.

Os finais de frase podem ser assinalados por uma combinação de diferentes características, tais como a redução rítmica, o relaxamento melódico determinado por uma queda de frequência, o uso de intervalos menores e de um menor número de notas, ou por qualquer outra forma adequada de diferenciação (SCHOENBERG, 2001, p.29 e 30).

${ }^{54}$ Até mesmo a escrita de frases simples envolve a invenção e o uso de motivos, mesmo que, talvez, inconscientemente. Usado de maneira consciente, o motivo deve produzir unidade, afinidade, coerência, lógica, compreensibilidade e fluência do discurso.

O motivo geralmente aparece de uma maneira marcante e característica ao início de uma peça. Os fatores constitutivos de um motivo são intervalares e rítmicos, combinados de modo a produzir um contorno que possui, normalmente, uma harmonia inerente. (SCHOENBERG, 2001, p.36). 
1. Aumento ou diminuição - onde se aumenta ou diminui a duração das notas de forma proporcional.

2. Inversão da linha melódica - aqui temos a inversão da direção do intervalo, esta inversão pode levar em conta a qualidade do intervalo (se ele é maior ou menor) ou apenas o tamanho do intervalo.

3. Retrogração - onde o motivo aparece em sentido contrário, de trás para frente.

\subsection{ACOMPANHAMENTO PIANÍSTICO}

O acompanhamento não deve ser uma mera adição à melodia. Deve ser o mais funcional possível e, nos melhores casos, atuar como complemento às essências de seu assunto: tonalidade, ritmo, fraseio, perfil melódico, caráter e clima expressivo. Deve revelar, também, a harmonia inerente do tema, estabelecer um movimento unificador, satisfazer às necessidades e explorar os recursos instrumentais... $\mathrm{Na}$ música descritiva, o acompanhamento contribui muito para a determinação de uma sonoridade expressiva (SCHOENBERG, 2001, p.107).

Nosso primeiro olhar no acompanhamento dirige-se à harmonia, que nos revelará se ela é simples ou se traz inovações, e principalmente, permitirá a visualização de como as alterações harmônicas são utilizadas para enfatizar o sentido da poesia. É interessante observar se as cadências finais estão associadas às emoções presentes no texto poético (por exemplo: a resolução final de ansiedade ou a busca de libertação, realização).

O acompanhamento que sustenta o cantor pode ser formado por diferentes possibilidades de textura, entre elas: acordes simples, acordes simples quebrados com figuras rítmicas repetidas, texturas contrapontísticas com várias linhas que podem se deslocar juntas ou umas contra as outras, uma mesma textura em toda a peça ou mudanças de textura.

A textura do acompanhamento engloba tanto a apresentação harmônica como a melódica. Podemos classificar as texturas de acompanhamento em três tipos principais: melodia acompanhada, homofonia e textura contrapontística. 
A mais simples dentre elas é a textura homofônica ou textura de acordes. Schoenberg (2008, p. 29) afirma: "Na música harmônico homofônica, o conteúdo essencial está concentrado em uma só voz, a voz principal, que possui uma harmonia inerente". Nessa textura o acompanhamento está claramente subordinado à linha vocal, promovendo simplesmente uma base harmônica para a mesma.

A relação mais complexa entre acompanhamento e linha vocal acontece quando o acompanhamento possui uma característica melódica predominante. Neste caso o piano não está apenas dobrando a linha do cantor, mas fazendo um contraponto a esta. Isso é ainda mais evidente quando o acompanhamento tem independência melódica em relação à linha vocal.

A melodia no acompanhamento pode aparecer como dobramento da linha vocal, na mão direita; como contraponto também na mão direita; ou ainda como melodia na mão esquerda. Vale lembrar que as melodias que acompanham a linha vocal funcionam como personas e auxiliam na descrição do poema.

Os elementos melódicos do acompanhamento merecem atenção especial, pois têm a mesma importância da linha vocal. As melodias no baixo surtem grande efeito, pois são geralmente inesperadas.

Como foi feito anteriormente com a linha vocal, uma vez estudadas as características do acompanhamento, vamos identificar a persona do acompanhamento, processo mais desafiante do que a identificação vocal.

A diferenciação entre figuras de acompanhamento ${ }^{55}$ - que ajudam a descrever o cenário - e outros elementos do acompanhamento - que são consideradas vozes de personas - é crucial para o pianista, pois define o equilíbrio entre voz e piano. Frequentemente o acompanhamento apresenta efeitos que auxiliam na representação de aspectos da cena, mas não representa vozes ou personas.

No caso mais simples, o acompanhamento partilha a mesma persona e modo de endereço do cantor. Outra possibilidade é o acompanhamento não apenas sustentar o cantor, mas adicionar uma dimensão diferenciada a esta persona, ou seja, voz e piano representando dois lados da consciência do poeta ou dois

\footnotetext{
${ }^{55}$ Muitas vezes, um simples motivo de acompanhamento é usado ininterruptamente por toda uma seção, exceto nas cadências. (...) O motivo de acompanhamento, sendo um dispositivo unificador, tem de ser mantido durante um certo número de compassos ou frase, e mesmo que venha a ser variado, não deverá desaparecer por completo. Modificações de caráter, construção ou acréscimo na quantidade de acordes podem justificar ou, mesmo, requisitar uma modificação do acompanhamento (...) (SCHOENBERG, 2001, p. 112-113).
} 
aspectos do conflito do poeta. Neste caso, o modo de endereço ocorre na forma de um diálogo entre pianista e cantor, vacilando entre os dois lados do conflito.

O tipo mais complexo acontece quando o pianista representa não apenas uma, mas várias personas no decorrer da música, às vezes juntamente com a persona do cantor, outras vezes adicionando uma ou mais vozes ${ }^{56}$. Neste caso, o modo de endereço se altera com cada persona.

\subsection{DEFINIÇÕES SUBJETIVAS}

A idéia de que a música expressa algo é geralmente aceita. Tal como o jogo de xadrez, que não conta histórias, ou como a matemática, que não evoca emoções, a música, do ponto de vista puramente estético, não expressa nada de extramusical. Do ponto de vista psicológico, porém, nossa capacidade de associações mentais e emotivas é tão ilimitada quanto é limitada a mesma capacidade para repudiá-las. Desse modo, qualquer objeto pode provocar associações com objetos extramusicais (SCHOENBERG, 2001, p.120).

Anteriormente definimos a persona e o destinatário do Lied. Agora é imprescindível ao intérprete encontrar a essência do poema e entender a jornada psicológica da personagem. Para essa análise podemos comparar as características musicais com a maneira pela qual as emoções são expressas na fala.

A voz é um meio de expressão das emoções. O falar compreende uma série de signos que demonstram o estado físico e emocional da pessoa.

Aristóteles, na antiguidade clássica, dizia que os sons emitidos pela voz são os símbolos dos estados de alma. A análise clássica da linguagem Ihe atribuía, como função, externalizar o pensamento. (...) A linguagem é vista como tradução: manifestação sensível e externa da representação interna. Portanto temos, aqui, a função expressiva (MAGNANTI, 2001, p.1).

\footnotetext{
${ }^{56}$ O estilo pianístico não requer uma conservação rigorosa do número de vozes, tal como se dá na harmonização coral a quatro vozes. Se uma peça inicia em três ou quatro partes, esse número será, até certo ponto, constante; mas, às vezes, menos vozes são usadas (como se uma ou mais silenciassem) e, em outras, utiliza-se um número maior delas (como na orquestra, quando entram instrumentos adicionais, com vistas ao crescendo, acentuação, clímax ou outros efeitos especiais) (SCHOENBERG, 2001, p.112).
} 
Os signos utilizados na fala são naturalmente compreendidos em um diálogo. Essa compreensão não é racional, pois os signos estão embutidos no conteúdo da conversa. Há uma série de signos visuais e gestuais que também auxiliam a comunicação, mas neste momento focaremos a atenção apenas nas características da voz.

A psicodinâmica ${ }^{57}$ vocal caracteriza a forma como a voz é emitida e os efeitos que ela causa nos ouvintes. As diferentes formas de emissão acontecem em função de alterações na maneira como se respira, na inteligibilidade da articulação, na velocidade em que se fala ou até mesmo na predominância de determinada ressonância.

A definição da sonoridade do poema - que consiste em observar se existe a predominância de vogais claras (i, e, ó) ou escuras (a, ô, u), e também se aparecem consoantes muito marcadas - auxiliará a definição das características psicológicas fundamentais à interpretação tanto do cantor como do pianista.

Podemos começar a descrição da jornada psicológica verificando primeiramente se a pessoa está feliz ou triste, calma ou agitada. Para esse entendimento podemos comparar os signos característicos da fala com a escrita musical. Depois é preciso entender como esse estado psicológico ou de humor se altera no decorrer da música. É importante que o intérprete tenha em mente uma única palavra que descreva cada mudança de humor da personagem.

No gênero Lied dificilmente encontramos informações precisas de tempo ${ }^{58} \mathrm{e}$ caráter $^{59}$. As marcações de metrônomo são raras nesse gênero e as indicações presentes são muito subjetivas, dando margem a distintas interpretações.

Depois de estudado o texto poético, as frases musicais e o motivo gerador, temos uma ideia de qual será o tempo da peça. A descrição do ritmo harmônico da peça também é relevante nessa decisão, pois as mudanças ocorridas acabam

\footnotetext{
${ }^{57}$ Conjunto de fatores de natureza mental e emocional que motivam o comportamento humano.

${ }^{58}$ Entendemos tempo como o passo, o quão rápido ou o quão lento é a organização e a fluidez rítmica e métrica.

${ }^{59} \mathrm{O}$ termo caráter, quando aplicado à música, refere-se não somente à emoção que uma peça deveria produzir e ao estado de ânimo em que foi composta, mas também à maneira pela qual ela deve ser executada. É uma falácia pensar que as indicações de andamento determinam o caráter: na música clássica, ao menos, isto não é correto. Não existe apenas um caráter de scherzo, mas milhares. Um adágio é lento e um allegro é rápido: isto contribui em parte, mas não totalmente, para a expressão do caráter (SCHOENBERG, 2001, p.120).
} 
imprimindo um passo ou tempo de fluidez harmônica que influenciam o tempo. Quando o rítmico harmônico é mais movido, com mudanças a cada pulso, a peça é normalmente mais movida do que outra com o ritmo harmônico mais lento. A definição do tempo será feita ao final de nossa análise, uma vez que depende também do entendimento do estado emocional da personagem. 
4 ANÁLISES 


\subsection{DER ABENDSTERN}

Não há um registro correto sobre o ano de composição dessa peça, que provavelmente foi escrita entre os anos de 1830 e 1833. Esse era um trabalho de juventude que Clara e Robert não tratavam com seriedade. A composição não foi copiada para o Liederbuch.

Clara era ainda uma criança quando compôs este Lied. Já tinha feito sua estréia como criança prodígio e provavelmente este trabalho foi composto para fazer parte de seus concertos. Era comum que um intérprete virtuose apresentasse também as próprias composições em seus recitais.

\subsubsection{Análise poética e forma musical}

\section{Der Abendstern}

Bist du denn wirklich so fern, lieblicher, glänzender Stern?

Sehne mich stündlich von hier, Wandelnder, heimlich zu dir

Blickest so hell durch die Nacht,

still, bis die Sorge erwacht,

schimmerst am Morgen noch spät,

matt, wenn die Sonne ersteht.

Winket dein freundliches Licht

Frieden und Ruhe mir nicht?

\section{A Estrela da Noite}

Você está mesmo tão longe

querida estrela brilhante?

Com saudade mentalizo em segredo

Você que circunda a terra.

Brilhando durante toda a noite com tanta luz,

Silenciosa, até as preocupações acordam, mesmo quando já está amanhecendo, seu brilho ainda está lá, até o Sol acordar.

Será que sua luz alegre não me transmitirá paz e silêncio? 
Schau ich dich, blinkenden Stern, möcht' ich ja sterben so gern.
Quando olho você, estrela brilhante, Tenho vontade de morrer.

Esquema de rimas aabb. A querida estrela brilhante representa a figura do amado. É uma poesia com uma temática muito comum aos românticos, o desejo da morte como solução para um amor inatingível. Há duas possibilidades, a pessoa amada pode estar morta ou ser um amor impossível e em ambos os casos a morte parece ser a melhor solução para a personagem, que assim demonstra grande dificuldade em lidar com as emoções. As sílabas tônicas localizadas na leitura do texto coincidem na maioria das vezes com os primeiros tempos de cada compasso, o que demonstra a preocupação de Clara com a prosódia.

Clara opta por uma forma estrófica simples, próxima ainda da tradição do século XVIII.

\subsubsection{Linha melódica vocal}

O estilo é silábico em todas as estrofes. A tessitura é de uma oitava, (Fá3 a Fá4 $)^{60}$, mas na maior parte do tempo a melodia está entre o Sol3 e o Ré4. A melodia tem intervalos pequenos. As frases compreendem dois compassos e cada uma utiliza um verso do poema. A maioria inicia e termina na nota lá, com exceção da última frase que acaba com a nota fá; essa característica polariza a peça em torno desta nota. Os intervalos vão aumentando gradativamente: na primeira frase o intervalo é apenas de uma terça, retornando ao repouso em lá; na segunda é de uma quarta, na terceira atinge o clímax (compasso 6) com o maior intervalo da peça, uma sexta menor - este é o pico da tessitura. $\mathrm{Na}$ última frase o segundo tempo do compasso é atingido por graus conjuntos, o que a diferencia das frases anteriores.

Persona e para quem está cantando: A poesia está em primeira pessoa, portanto o cantor vivencia todas as emoções implícitas no poema. $O$ desejo da personagem em morrer no último verso da poesia é uma marca comum aos românticos, possivelmente essa era a única solução para estar próxima de sua

${ }^{60}$ No sistema adotado no Brasil, nomeia-se o Lá diapasão - 440 Hertz - de Lá3. (LIMA, 2006, p.35). 
estrela. A poesia parece ser uma reflexão da personagem como se ela estivesse pensando alto e, portanto não tem um destinatário. Para revelar esse caráter introspectivo na performance, é imprescindível que a tessitura seja confortável ao cantor para evitar que dificuldades técnicas interfiram na emoção expressa.

\subsubsection{Acompanhamento pianístico}

Textura e elementos melódicos: O acompanhamento é sempre acordal. Nos compassos 9 a 12 vê-se um pequeno interlúdio pianístico onde há uma presença melódica mais significativa. Anteriormente tivemos apenas uma breve presença melódica na segunda metade do compasso 6 (clímax da peça) quando a mão direita dobra a linha do cantor.

Persona: A persona passa para o piano durante os compassos 10 e 11 do interlúdio, quando há a apresentação de elementos melódicos. Os compassos de número 1 e 12 são apenas a afirmação da tonalidade para a entrada do cantor.

\subsubsection{Definições subjetivas}

Não temos a indicação de caráter ou andamento. Na linha vocal não aparecem indicações de dinâmica, mas na parte do piano temos algumas indicações: dolce no primeiro compasso; crescendo que se inicia no final do compasso 5 e decrescendo no início do compasso 7 - este crescendo sustentará o cantor no pico da tessitura, que é o ponto culminante da linha vocal. No compasso 9 aparece a indicação de $p$ na parte do piano.

Nesta poesia há a predominância de vogais claras. Como o texto exprime a saudade da pessoa amada que por uma razão desconhecida está inatingível, o andamento e a dinâmica escolhidos devem transmitir ao ouvinte o amor e a saudade capazes de levar a personagem a desejar a morte. 
Der Abendstern

Erstdruck
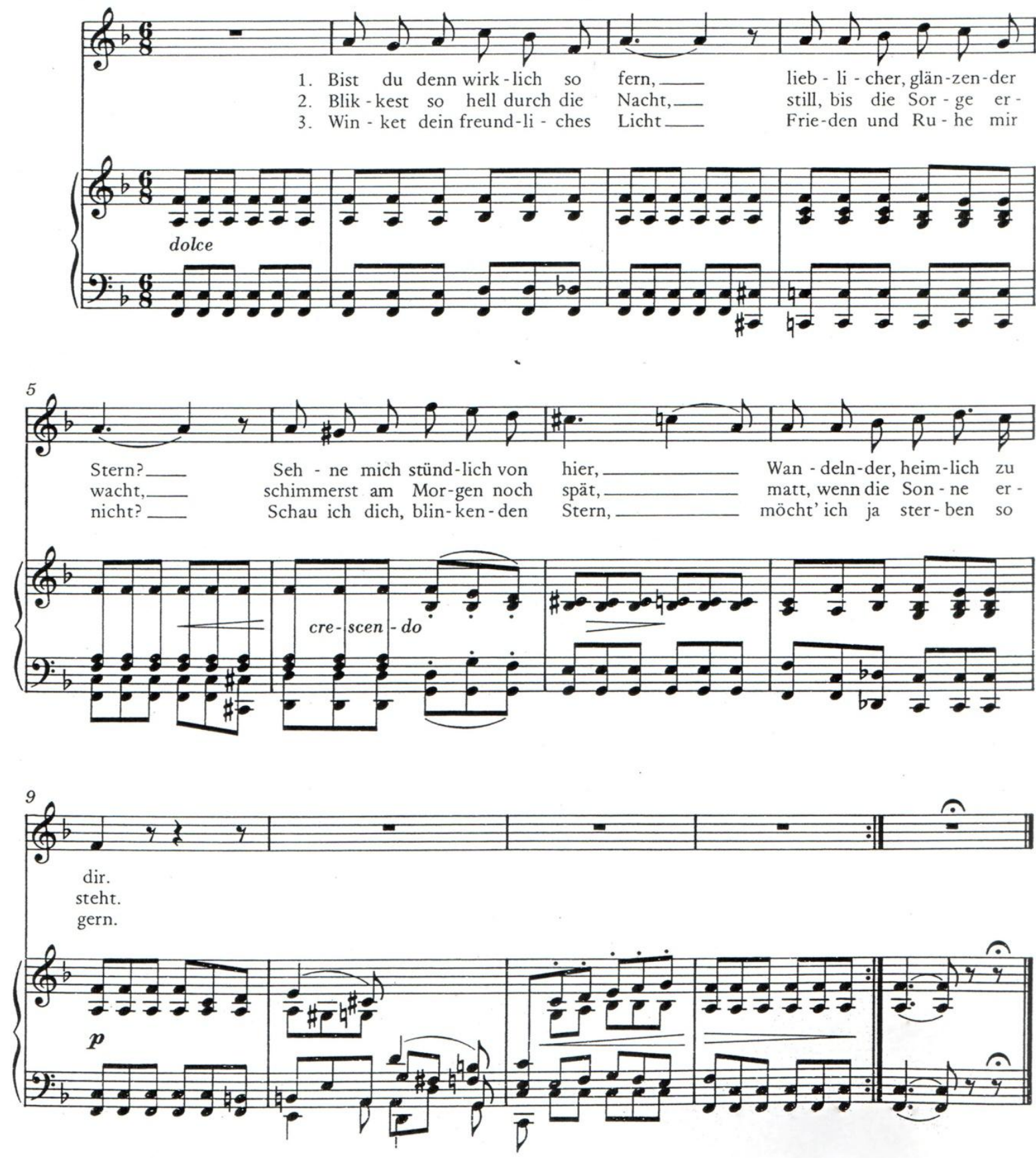


\subsection{VOLKSLIED}

Dedicatória: "com a mais profunda humildade, dedicado ao meu amado Robert no Natal de 1840"

\section{Am Strande \\ Ihr Bildnis \\ Volkslied}

Depois de ganhar esse presente Schumann decidiu musicar a poesia Volkslied.

Neste período o casal vivenciava momentos muito felizes, eram os primeiros meses juntos. A única coisa que entristecia Clara era o desentendimento com seu pai.

\subsubsection{Análise poética e forma musical}

\section{Volkslied}

(Heinrich Heine)

Es fiel ein Reif in der Frühlingsnacht, er fiel auf die zarten Blaublümelein:

Sie sind verwelket, verdorrt.

Ein Jüngling hatte ein Mädchen lieb;

sie flohen heimlich von Hause fort, es wußt' weder Vater noch Mutter.

\section{Canção Popular}

Caiu uma geada na noite de primavera,

Ela caiu sobre as delicadas florzinhas azuis:

E elas tornaram-se murchas, secas.

Um jovenzinho tinha amor por uma moça;

Eles fugiram secretamente de casa,

Disso não sabiam nem o pai nem a mãe. 
Sie sind gewandert hin und her, sie haben gehabt weder Glück noch Stern, sie sind gestorben, verdorben.
Eles vagaram por aqui e por ali, Eles não tiveram felicidade nem sorte, Eles morreram, arruinaram-se/ apodreceram.

Não há rimas de finais de frase, mas verificamos parentesco sonoro em toda a poesia. Há muitas repetições de consoantes e vogais em cada verso, soando como rimas internas; um exemplo bem evidente aparece no último verso da terceira estrofe - sie sind gestorben, verdorben.

Existe uma semelhança semântica entre a primeira e terceira estrofe: As flores murcham/ Os jovens arruínam-se - são utilizados até verbos parecidos, verdorben e verdorren. É possível entender a morte dos jovens de maneira figurativa, talvez eles tenham morrido perante a família. Eles podem passar por um processo semelhante ao que ocorre com as flores citadas na primeira estrofe, elas ficam murchas e sem vida durante um período em função de uma noite gelada como se fosse inverno, mas elas brotam novamente durante o restante da primavera.

Podemos dividir esse Lied em ABA'. A escolha formal feita pela compositora demonstra que ela captou a semelhança entre a primeira e a terceira estrofe. $\mathrm{Na}$ seção A temos uma introdução do piano que compreende 3 compassos, e apresenta o material temático da peça. Este material será modificado para permitir a alteração de emoção que acontece na parte $B$. O término da seção A é no compasso 8 . A voz faz uma apojatura em sua resolução no compasso 9, e na parte do piano, essas mesmas notas são repetidas ao mesmo tempo que iniciam a seção $B$.

Como foi dito anteriormente, a seção $B$ utiliza o mesmo material melódico da A. Nesta seção temos a sensação de maior fluidez, mesmo sem alteração de andamento. Na reexposição de $\mathrm{A}$, que se inicia no compasso 16 , temos a reapresentação da introdução, não restando dúvidas de que Clara compreendeu a semelhança da primeira e terceira estrofes. A repetição da introdução leva o ouvinte de volta ao clima tenso e dramático, tempo necessário para se preparar para a volta do texto que narrará o fim trágico dos amantes. 


\subsubsection{Linha melódica vocal}

A linha vocal na primeira parte é mais declamada em função dos saltos e das notas repetidas, que conferem uma dramaticidade diferente para o Lieder em questão. ${ }^{61}$

A tessitura é de uma décima primeira (Dó3 a Fá4). No compasso 6 temos a mesma ideia de pergunta exposta no início, mas agora quem apresenta a primeira dúvida é o cantor, e o piano a repete uma quarta acima.

No compasso 8 temos um tempo de pausa na parte do piano. Apesar de sua curta duração, essa pausa é extremamente expressiva (o texto diz: Sie sind verwelket, verdorrt - elas tornaram-se murchas, secas). Esse é o único momento em que o piano para o movimento contínuo que caracteriza sua parte, o que aumenta a expectativa e dramaticidade da entrada do cantor.

Na parte B temos o ápice da peça, que acontece nos compassos 13 e 14, na nota mais aguda e também mais longa, se levarmos em consideração suas repetições resultantes da alteração de sílabas. Nesse caso praticamente omitimos a vírgula presente no compasso 13 e fazemos com que essa seja a maior frase da peça. A voz termina essa seção também com uma apojatura, semelhante ao que aconteceu na seção anterior, mas dessa vez o piano finaliza o compasso concluindo a seção.

No compasso 23 para 24 quando o texto expõe: sie sind gestorben, verdorben - eles morreram, arruinaram-se ou apodreceram, Clara utiliza a mesma proposta que Schumann utilizara na última peça do ciclo Frauenliebe und Leben quando a figura perfeita do amado morre calando a voz da cantora e deixando a voz poética (persona) para o piano. Clara escreve um poslúdio derivado de uma variação da ideia melódica principal da peça.

Persona e para quem está cantando: Poesia em terceira pessoa. Nessa poesia o cantor é um narrador, portanto pode criar suspense e exagerar nas surpresas. O cantor está sempre recriando a história para quem está ouvindo, mas em momento algum chega realmente a sentir as emoções que está transmitindo. $O$ caráter não é intimista e o destinatário é o público.

\footnotetext{
${ }^{61}$ Os Lieder de Clara são mais marcados por um grande arco melódico, que nos remete muito mais a Schubert do que a Schumann.
} 


\subsubsection{Acompanhamento pianístico}

Textura e elementos melódicos: O piano inicia a apresentação do material melódico a ser desenvolvido no decorrer da peça. $\mathrm{Na}$ introdução apresenta-se uma pergunta que é reafirmada uma terça acima, essa ideia aparecerá alterada em diferentes momentos da obra. A voz do soprano na parte do piano dobra a melodia do canto, não exatamente nota por nota durante toda a peça, mas fornecendo ao cantor um suporte.

Na seção $B$ temos a sensação de maior fluidez, não havendo alterações de andamento. A repetição dos acordes cheios na parte do piano cria essa percepção e altera o caráter. Nesse momento o piano nos parece mais um acompanhador que faz algumas interjeições pontuando a linha do canto.

Persona: a grande participação do piano como persona é no poslúdio final. Encontramos aí ao menos duas possibilidades: se entendemos que a morte dos personagens é apenas figurativa, o poslúdio pode trazer a esperança de um futuro melhor. Entretanto, se entendemos a morte como literal, esse poslúdio deve reafirmar a dramaticidade e tensão poética construídas até este momento. $\mathrm{O}$ interlúdio final dá espaço à imaginação do ouvinte, que pode criar o seu final individualmente de acordo com a interpretação do pianista.

\subsubsection{Definições subjetivas}

Nesta peça verificamos uma riqueza maior de indicações de caráter, andamento e dinâmica que não deixam dúvidas quanto à interpretação. $O$ andamento é adagio e aparece a indicação Schwermütig (melancólico) para o cantor. No decorrer da peça encontramos marcações detalhadas de articulação, indicações de dinâmica, crescendo e decrescendo. O intérprete não tem muito espaço para criar, a melhor opção é respeitar as marcações existentes. Clara utilizou recursos da fala na composição dessa peça: geralmente ao falarmos emitimos os tons agudos em momentos festivos e alegres, enquanto os tons graves são usados em situações mais sérias e melancólicas. 
Volkslied

(Heinrich Heine)

Erstdruck

Adagio

Schwermütig

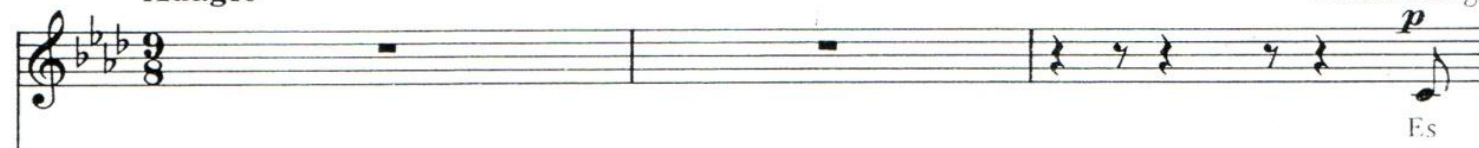
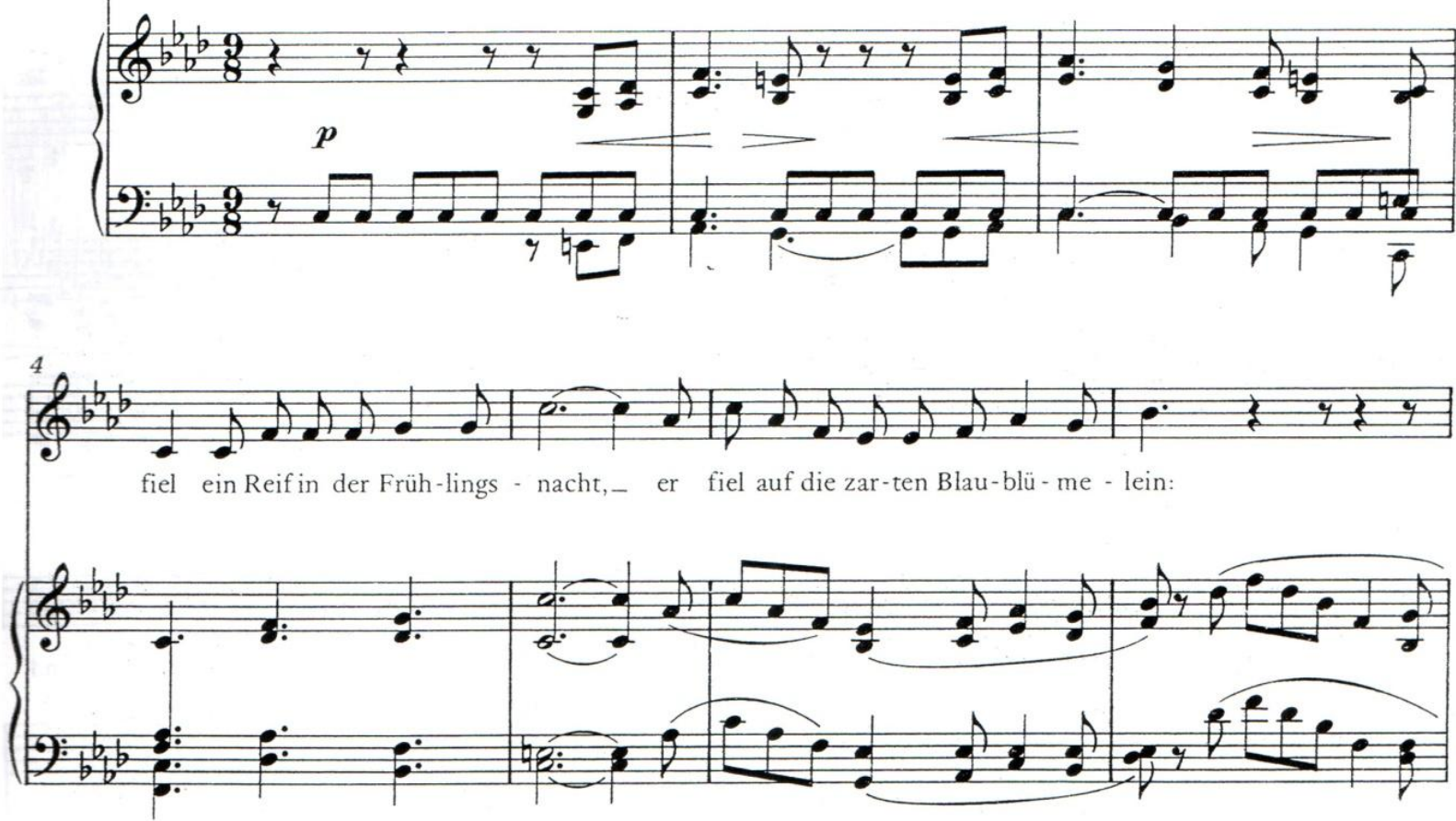

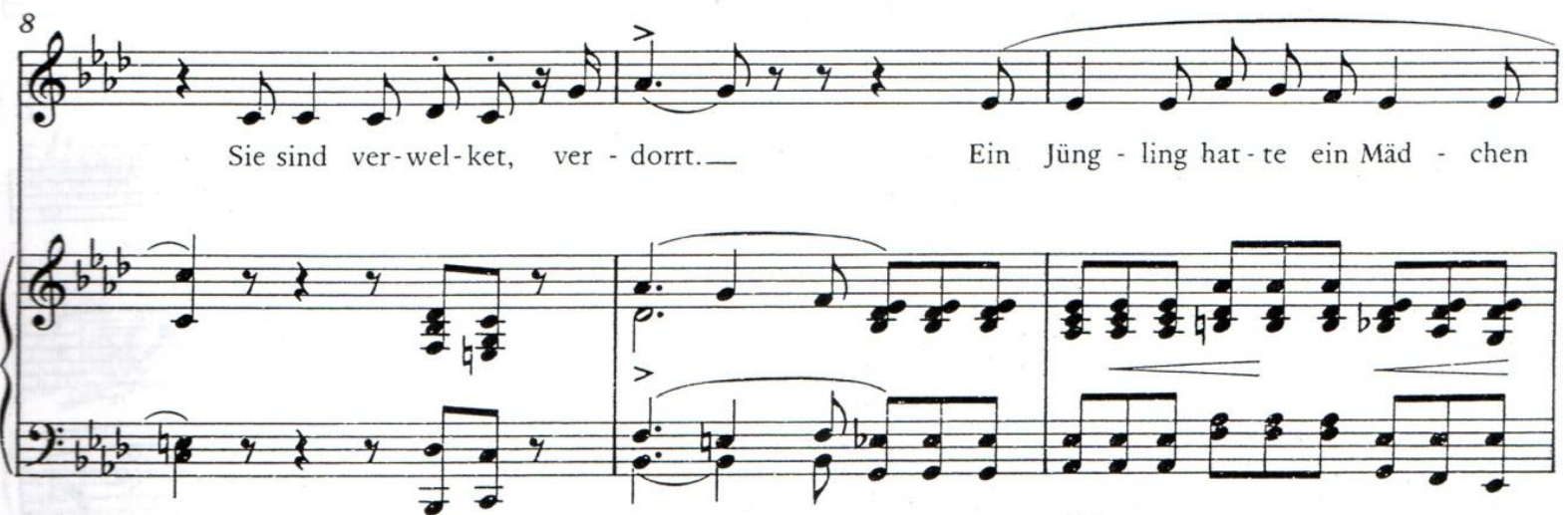


84
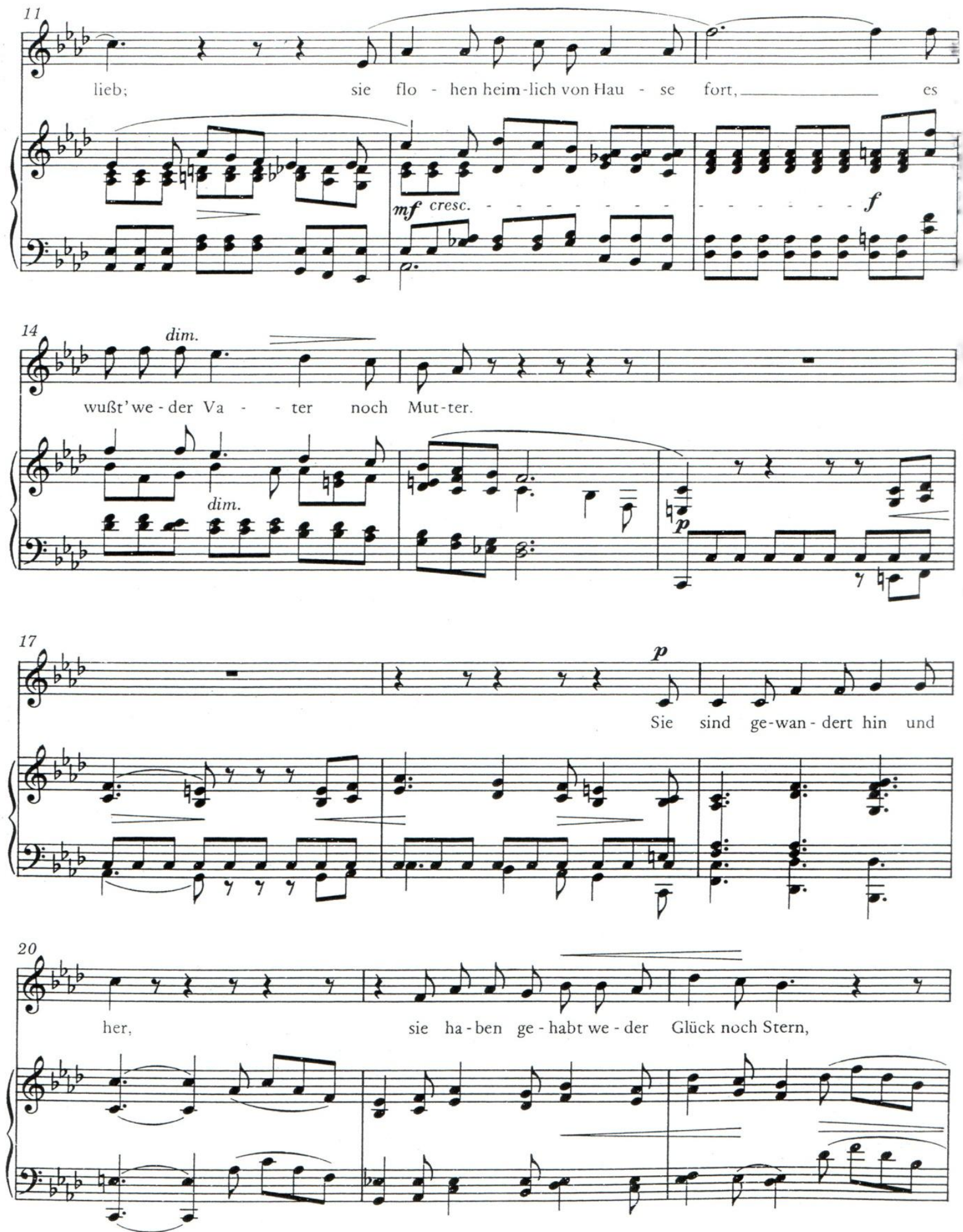

Wb. 2242 

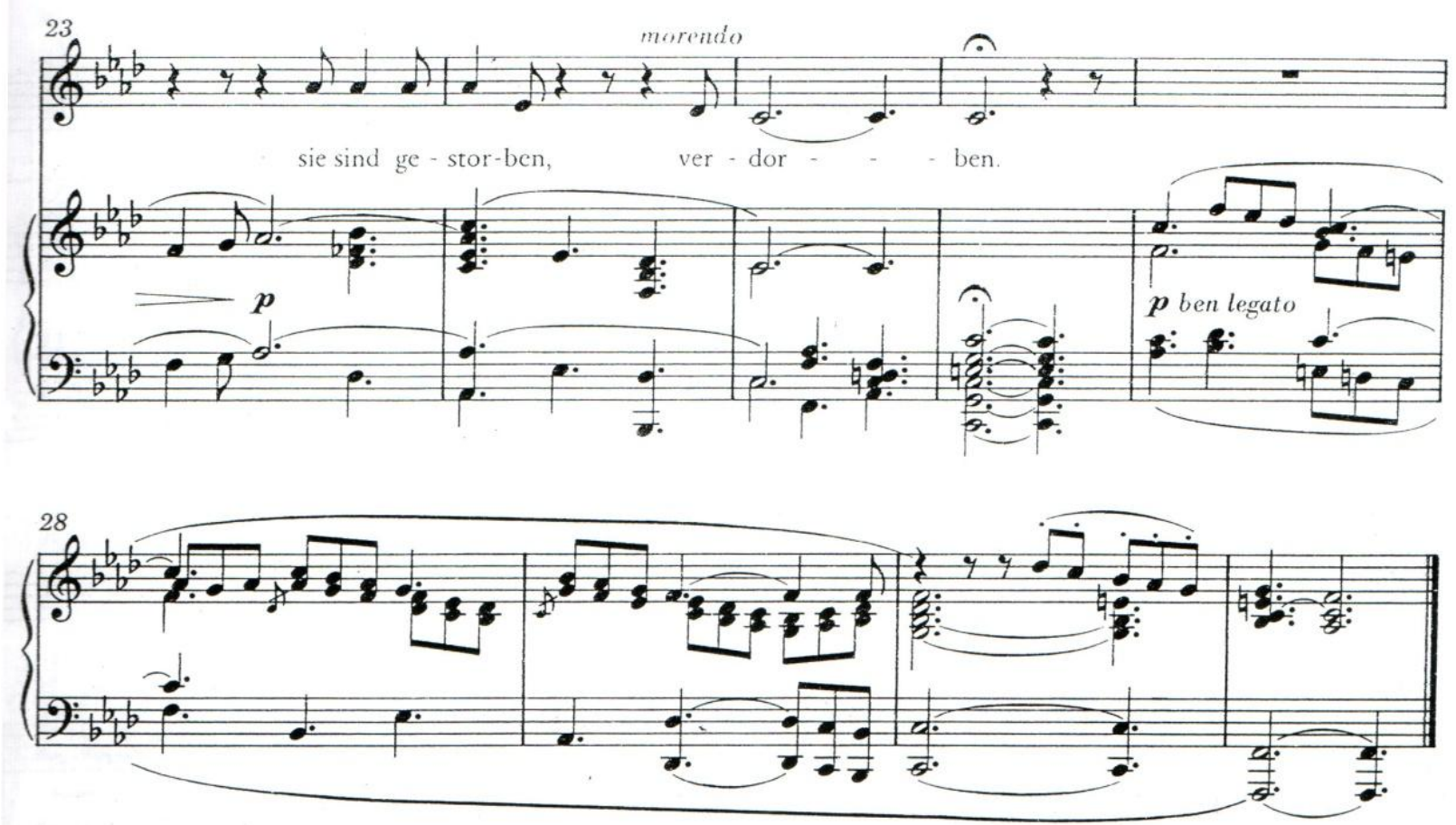


\title{
4.3 DIE GUTE NACHT, DIE ICH DIR SAGE
}

Dedicatória: "ao meu amado marido em 8 de junho de 1841, composto por sua Clara"

\author{
Quatro poemas de Rückert: \\ Warum willst Du And're fragen? \\ Er ist gekommen \\ Liebst Du um Schönheit \\ Die gute Nacht
}

Este foi um poema musicado para o aniversário de Schumann do ano de 1841 , sendo que esta foi a única peça desta coletânea a não ser publicada no ciclo Liebesfrühling.

Schumann estava entretido na composição de sua primeira sinfonia e Clara experimentava os primeiros momentos de solidão e dúvidas acerca do amor do seu marido. Ela lembra a personagem de Frauenliebe und Leben, que no terceiro Lied do ciclo não consegue acreditar que um homem tão maravilhoso possa estar interessado por ela. Clara estava grávida de sua primeira filha.

\subsubsection{Análise poética e forma musical}

Die gute Nacht, die ich dir sage

(Friedrich Rückert)

Die gute Nacht, die ich dir sage, Freund, hörest $d u^{62}$ !

Ein Engel, der die Botschaft trage

\section{A boa noite, que eu te digo}

A boa noite, que eu te digo, Amigo, ouça-a!

Um anjo, que carrega esta mensagem,

\footnotetext{
${ }^{62}$ Forma interessante de imperativo, própria do tratamento formal Sie. Para o tratamento $d u$ seria simplesmente Hör!
} 
geht $a b$ und $z u$.

Er bringt sie dir und hat mir wieder den Gruß gebracht:

Dir sagen auch des Freundes Lieder

jetzt gute Nacht.
Vai, de vez em quando,

Leva-a para você e traz de volta A saudação:

As canções do amigo também te dizem

Agora, boa noite.

Rimas cruzadas: abab/ cdcd. Esta poesia está relacionada à separação. Pode ser um simples desejo de 'boa noite' muito usual na cultura alemã, no entanto é carregado por um anjo, nos fazendo entender que existe uma distância implícita. tamanho dessa distância não é definido, pode ser um espaço físico ou até mesmo a morte; no segundo caso a saudação seria uma despedida. O amigo pode ser considerado a pessoa amada e o intérprete pode escolher o entendimento que lhe pareça mais interessante para sua performance.

A forma é ternária AA'BA. Tanto a poesia quanto as seções da peça são muito curtas. Do compasso 1 ao 16 temos a apresentação do material melódico da seção A na forma de uma introdução quase recitada, onde o acompanhamento pianístico é homofônico e promove apenas a sustentação harmônica para o cantor. Da anacruse do compasso 17 até o 23 temos a seção $A$, que será repetida com alterações na linha vocal e no acompanhamento, nos compassos 39 a 48 - seção A'. A escrita pianística dessa seção nos remete aos momentos Eusebius da obra schumanniana, caracterizado pelos acordes arpejados que conferem à peça fluidez e simplicidade.

No compasso 25 começa a seção $B$, com uma grande mudança na textura pianística. Temos agora acordes repetidos, e essa seção que se inicia com a modulação para a mediante é muito curta, compreendendo apenas 2 versos da poesia. Nos compassos 37 e 38 temos a modulação rápida para retornar à tônica para a reexposição da seção A. A partir do compasso 49 temos um poslúdio, uma citação do poslúdio da peça 7 do ciclo Frauenliebe und Leben de Schumann. Nesse Lied a personagem narra a alegria e emoção que uma mãe sente por poder gerar e amamentar seu filho. Clara estava grávida de sua primeira filha ao compor Die gute Nacht e provavelmente apenas nesse momento conseguia compreender o conteúdo deste Lied de Schumann. 


\subsubsection{Linha melódica vocal}

O estilo é silábico e a tessitura é de uma oitava, de Fá3 a Fá4. As frases da introdução são curtas e englobam pequenos intervalos. A partir do compasso 17 elas ficam maiores, de modo que a seção $B$ apresenta uma única frase de 5 compassos. Essa frase é o ápice da música por algumas razões: o tamanho dela; a indicação de legato na linha vocal; e a mudança de textura do acompanhamento; informações novas na peça, portanto se destacam e prendem a atenção do ouvinte.

Persona e para quem está cantando: A poesia é em primeira pessoa e seu caráter é muito intimista, dando a impressão de que esse é um desejo de uma personagem apaixonada, como se o ouvinte pudesse captar seus pensamentos. As indicações de dinâmica não ultrapassam um $m f$, e nos parece improvável imaginar uma pessoa que deseja boa noite utilizar uma intensidade exagerada. O destinatário é a pessoa amada que não pode ouvir, pois não está presente, mas que é real e na imaginação da nossa personagem é capaz de captar sua mensagem.

\subsubsection{Acompanhamento pianístico}

Textura: Até o compasso 16 temos os acordes homofônicos sustentados por longos períodos, uma escrita composicional que lembra a escrita para órgão. Do compasso 17 a 21 temos a utilização dos acordes arpejados com algumas notas de passagem. E do compasso 23 a 38 temos os acordes repetidos.

Elementos melódicos: O poslúdio que começa no compasso 49 - que pode ser considerado uma homenagem a Schumann ou uma menção ao poslúdio da peça que narra a alegria de uma mulher esperando seu primeiro filho - pode a uma primeira vista se configurar como a apresentação de um material novo, mas um olhar mais atento mostra que essa ideia já havia sido apresentada no acompanhamento dos compassos 17 a 21 por exemplo. 
Persona: a função do piano é de sustentação harmônica e ambientação poética, assumindo a persona apenas no posludio.

\subsubsection{Definições subjetivas}

A indicação de andamento é Andante e a indicação de caráter é Sehr einfach - muito simples. As indicações de dinâmica mantém a peça de pp a $m f$, portanto nada é muito exagerado. $\mathrm{O}$ andamento não pode ser muito lento, pois o piano não consegue sustentar as notas longas do início. O tipo de escrita composicional da peça dá a impressão de que o andamento é mais rápido na seção $\mathrm{B}$, por isso é importante que exista uma igualdade rítmica do início ao fim da peça para que essa sensação não seja exagerada, alterando seu caráter.

Die gute Nacht, die ich dir sage

(Friedrich Rückert)

Erstdruck
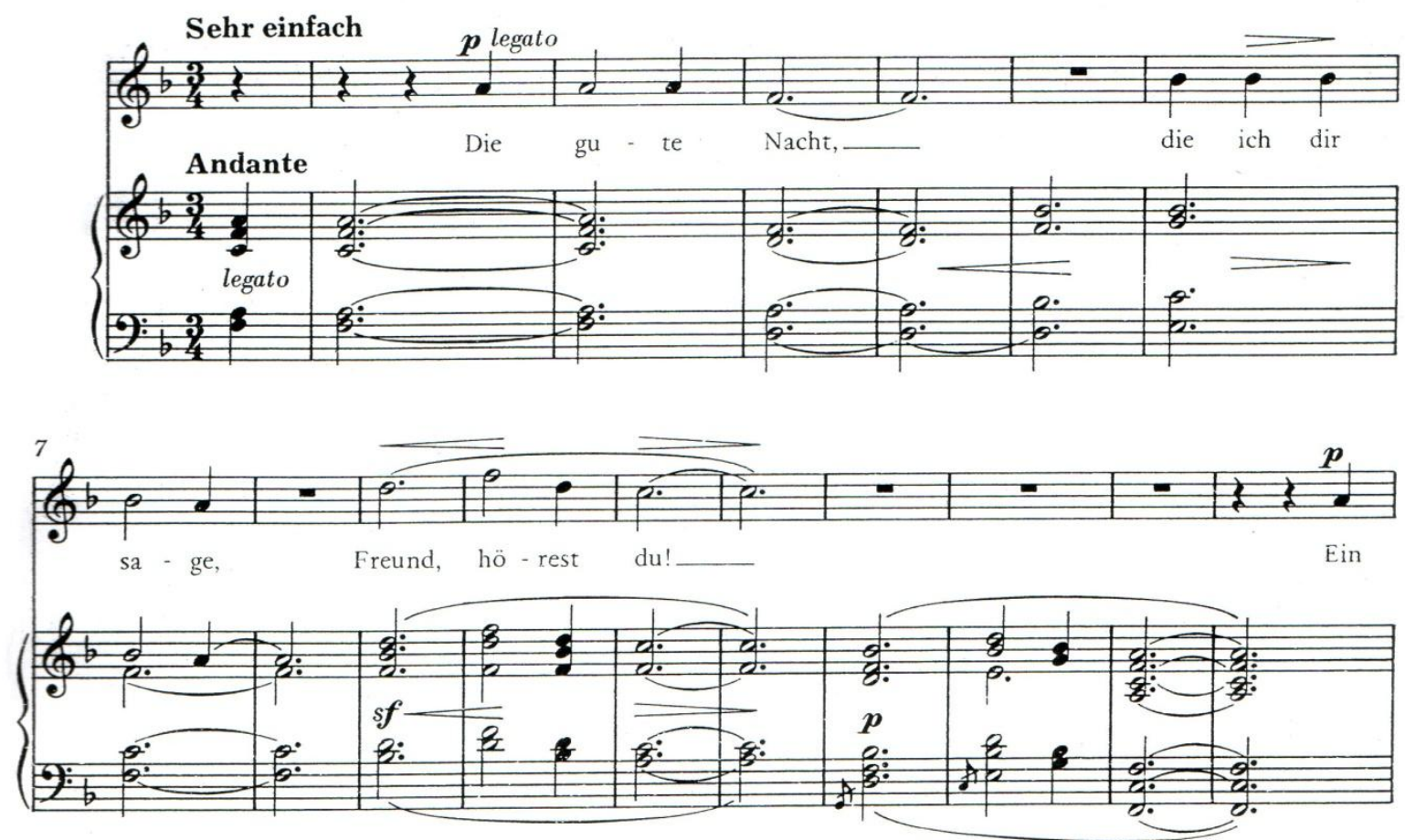

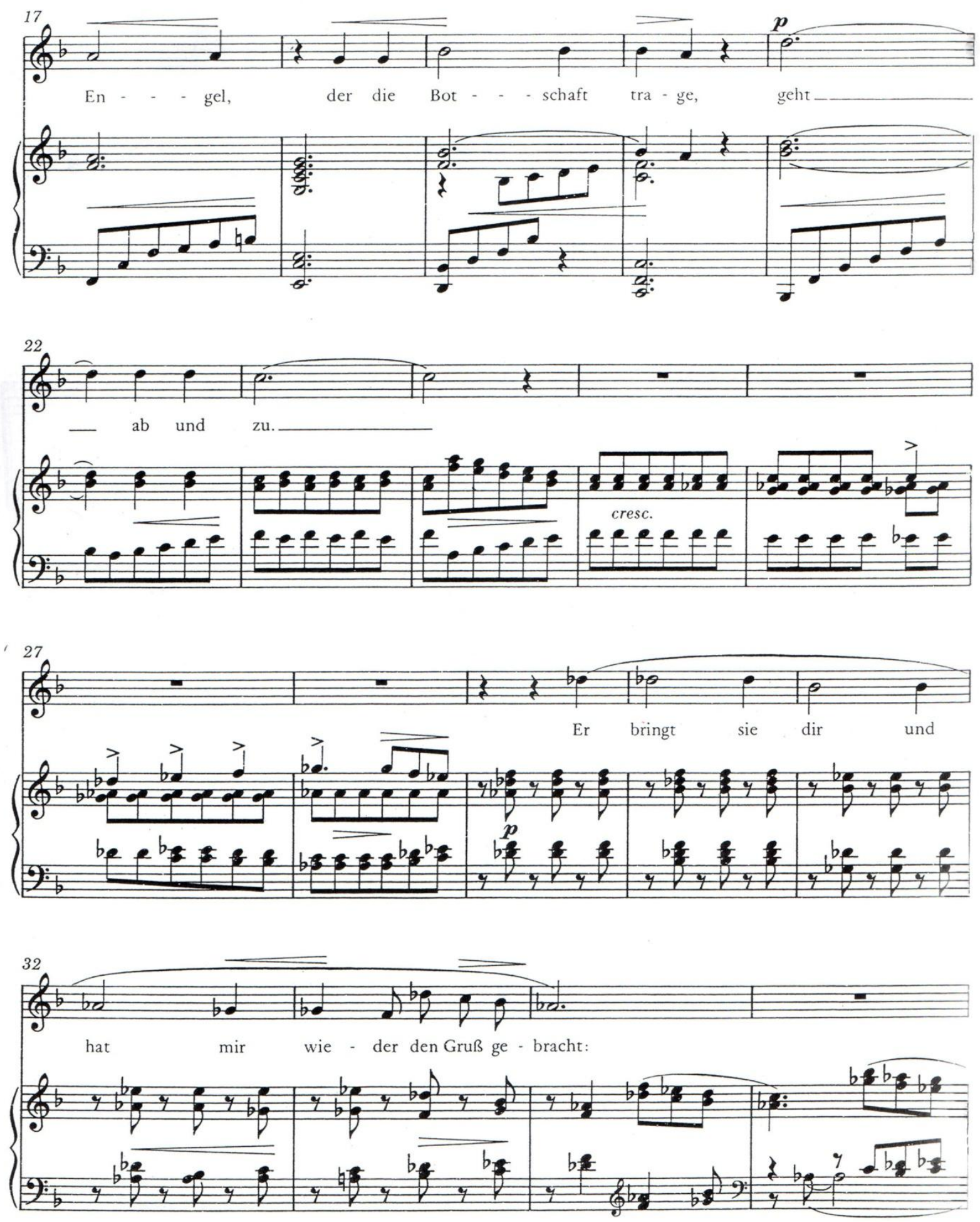

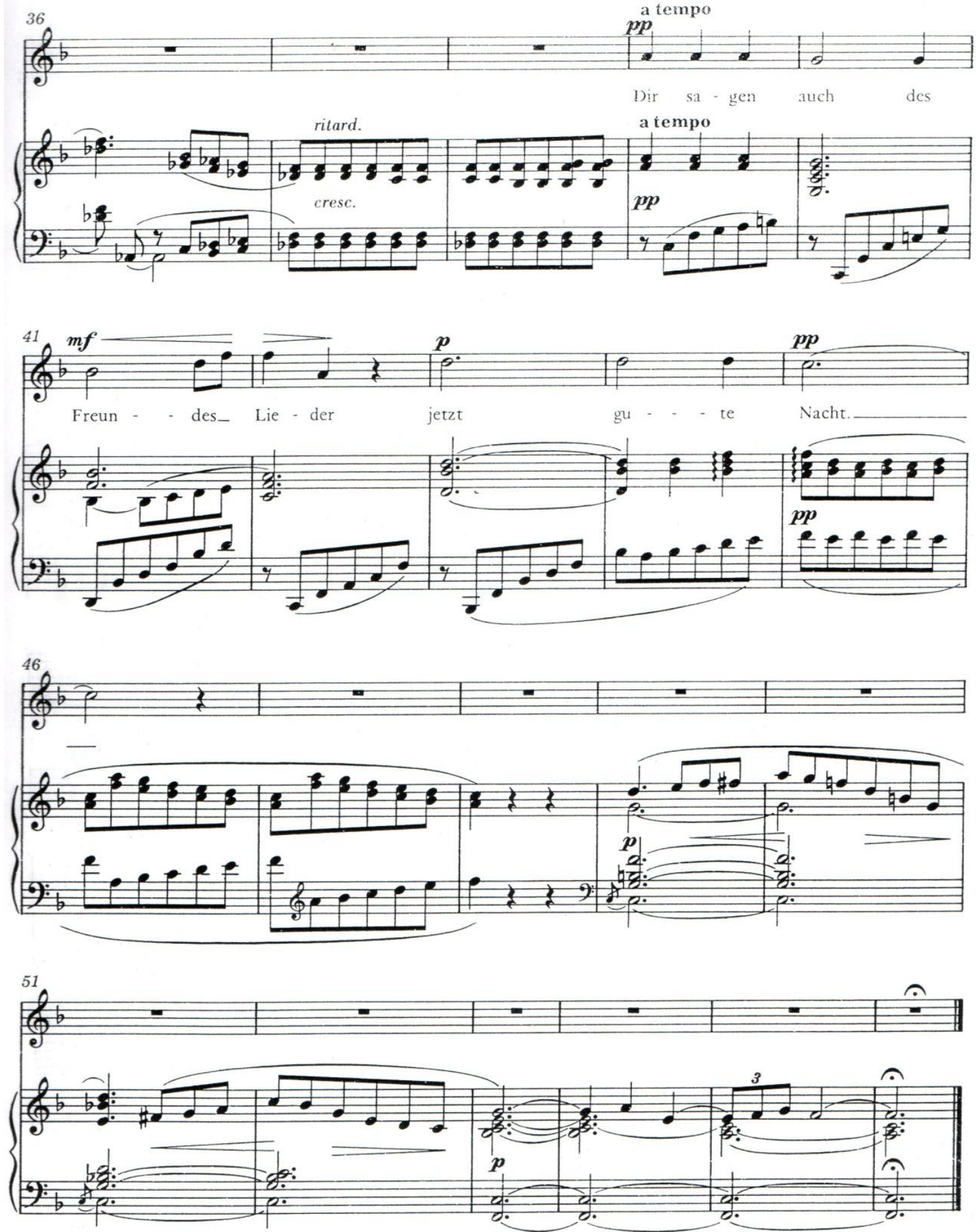


\subsection{LORELEI}

Dedicatória: "Ao meu amado marido em 8 de junho de 1843."

\section{Lorelei}

Ich hab' in deinem Auge

O weh des Scheidens

Clara já tinha vivenciado momentos de muita tristeza, nos quais acreditava que seu querido Robert não a amava mais. Ela escreve esse Lied alguns meses após uma breve turnê em fevereiro daquele mesmo ano. Nesta turnê Robert cansouse da posição insignificante em que ele ficava nesses eventos - era considerado apenas o marido da virtuose. E, em uma decisão repentina deixa Clara sozinha em sua turnê e retorna para Leipzig.

\subsubsection{Análise poética e forma musical.}

\section{Lorelei}

(Heinrich Heine)

Ich weiß nicht, was soll es bedeuten

Daß ich so traurig bin;

Ein Märchen aus alten Zeiten

Das kommt mir nicht aus dem Sinn.

Die Luft ist kühl und es dunkelt,

Und ruhig fließt der Rhein;

Der Gipfel des Berges funkelt

Im Abendsonnenschein.

\section{Lorelei}

Eu não sei bem o motivo

De eu me encontrar tão tristonho;

Um conto de fadas de tempos antigos

Não me sai da cabeça. ${ }^{63}$
A brisa é fria e está escurecendo,
O Reno flui calmamente;
No cume do morro resplandece
No brilho do sol antes de ele se por.

\footnotetext{
${ }^{63}$ Parece que nessa primeira estrofe o narrador introduz o assunto. Daqui em diante ele vai narrar esse conto de fadas.
} 
Die schönste Jungfrau sitzet

Dort oben wunderbar, Ihr gold'nes Geschmeide blitzet

Sie kämmt ihr gold'nes Haar.

Sie kämmt es mit gold'nem Kamme

Und singt ein Lied dabei;

Das hat eine wundersame

Gewaltige Melodei. ${ }^{64}$

Den Schiffer im kleinen Schiffe ergreift es mit wildem Weh,

Er schaut nicht die Felsenriffe,

Er schaut nur hinauf in die Höh.

Ich glaube, die Wellen verschlingen

Am Ende Schiffer und Kahn;

Und das hat mit ihrem Singen

Die Lorelei getan.
A virgem mais bonita está sentada

Lá em cima, maravilhosa

Suas jóias douradas brilham,

E ela penteia seus cabelos dourados.

Ela os penteia com um pente dourado,

Enquanto canta uma canção,

Uma canção cuja melodia é maravilhosa,

E imponente.

O marinheiro, em seu pequeno barco,

É tomado por muita aflição.

Ele não mira o rochedo,

Ele só olha para as alturas. [para o

cume onde está a moça]

Eu creio ${ }^{65}$, que no final, as ondas

Engoliram o marinheiro e o barquinho,

$E$ isso com sua canção,

É que a Lorelei o fez.

Rimas intercaladas abab. Heine escreveu este poema em 1823, e foi publicado em 1824. Seu primeiro título foi 'Lore-Ley', mas também aparece com as grafias 'Lorelei' ou 'Loreley'. A história da Lorelei não é uma lenda antiga, mas sim um poema em forma balada escrito por Clemens Brentano no início do século XIX. Outros tratamentos literários dessa história apareceram antes dessa versão do Heine. Lurlei ou "penhasco dos duendes" era o antigo nome dado para o perigoso penhasco no rio Reno entre St. Gaor e Oberwesel. Em seu poema, Brentano transformou o penhasco em um nome de mulher. No Liederkreis op.30 de Robert Schumann (poesia de Eichendorff), a bruxa Lorelei é encontrada na floresta

\footnotetext{
${ }^{64}$ A palavra é melodie, é alterada para rimar.

${ }^{65}$ Primeira manifestação pessoal do narrador.
} 
(Waldesgespräch), longe do seu castelo no Reno. Ela aparece para um caçador e terrivelmente promete que ele nunca deixará a floresta.

Essa poesia de Heine foi musicada por outros cinco compositores. Provavelmente a versão mais conhecida é a de Franz Liszt.

A forma musical é singular, desenvolvendo-se paralelamente ao desenvolvimento poético. Nos dois primeiros versos a personagem se pergunta o motivo de ela estar se sentindo tão triste. Clara escreve duas frases ascendentes que se complementam e que representam muito bem a dúvida. Nos compassos 5 a 8 temos a apresentação de uma melodia no piano, que pode ser entendida como o canto da Lorelei, como se o instrumento antecipasse o que se passa na cabeça da personagem. Essa mesma melodia aparece na linha vocal nos compassos 9 a 12 quando o cantor fala: "Um conto de fadas de tempos antigos não me sai da cabeça". Nos compassos 13 a 20 temos a repetição expandida da primeira ideia apresentada. No compasso 20 a parte do piano sofre uma alteração de textura, esta passa a ser mais delicada para representar os encantos e a sedução da Lorelei, e inclui uma participação melódica - o baixo da mão esquerda faz um dueto em sextas com a linha vocal que nesse momento também assume um caráter mais melódico e legato. As indicações de crescendi e decrescendi são mais frequentes. No compasso 350 texto é: "enquanto canta uma canção" a melodia apresentada nos compassos 5 a 8 é repetida na parte do piano nos compassos 37 a 39 e na anacruse do compasso 41 o cantor entoa essa mesma melodia e suas palavras descrevem-na.

A partir do compasso 45 será descrita a aflição do marinheiro, e no compasso 47 o acompanhamento retorna à sua textura inicial. São acrescentados sf para aumentar a tensão. A linha vocal passa a entoar notas repetidas, neste momento o desespero é tão grande que não permite o uso de melodias: como se o marinheiro gritasse e para ser ouvido utilizasse frequências mais agudas.

\subsubsection{Linha melódica vocal}

O estilo é silábico. Alguns trechos são mais parlato pela presença de notas repetidas. A dramaticidade dessa peça e as dinâmicas que a compositora pede dão 
a ela um caráter mais operístico do que as outras composições analisadas neste trabalho.

A tessitura é de Ré3 a Sol4. O clímax da peça está no compasso 61 e 62, momento em que se está no pico da tessitura e da intensidade em notas de maior duração. As frases são curtas, aproximadamente dois compassos e englobam um verso da poesia. A única exceção acontece nos compassos 39 a 44, quando temos a união de dois versos em uma frase mais longa. No contorno melódico há a predominância de graus conjuntos.

Persona e para quem está cantando: A poesia começa na primeira pessoa, na segunda estrofe a personagem mergulha em sua imaginação e começa a narrar o conto da Lorelei - uma linda bruxa que vive na floresta e em seu castelo às margens do Reno. Seu canto e beleza seduzem os homens que ficam presos para sempre na floresta onde ela mora (uma ideia semelhante à lenda da sereia). A narração do conto acontece durante três estrofes; na última a personagem retoma seu discurso em primeira pessoa ao supor o final do conto. Por se tratar de uma lenda, não se sabe ao certo qual é o destino exato dos homens seduzidos pela Lorelei: possivelmente é a morte. Esse Lied é direcionado a todos, como uma espécie de advertência a respeito dos encantos fatais dessa bruxa.

\subsubsection{Acompanhamento pianístico}

O acompanhamento exige virtuosismo técnico do pianista. Temos notas repetidas do início ao fim da peça.

Textura e elementos melódicos: Temos duas texturas, uma de acordes repetidos e outra de acordes arpejados. O elemento musical é a melodia da Lorelei.

Persona: o piano tem uma função descritiva ou de ambientar o ouvinte em grande parte da peça. Ele pode ser considerado uma persona apenas nos momentos em que executa a melodia da Lorelei.

\subsubsection{Definições subjetivas}


A indicação de andamento é Schnell - rápido e não há nenhuma indicação de caráter. Ao se falar rapidamente transmite-se ansiedade, e esta é uma característica muito presente nesta peça. No entanto, rápido é uma indicação vaga; portanto o intérprete precisa encontrar um tempo em que seja possível para o pianista tocar todas as notas claramente e para o cantor manter uma boa dicção do texto. Nos momentos de tensão ou contenção de sentimentos a articulação é travada e a articulação exagerada aparece geralmente na afetação ou no narcisismo, estes dois sentimentos estão muito presentes nesta composição, por isso o cantor deve ter um cuidado especial com a articulação do texto. $O$ intérprete pode modificar a duração da articulação das palavras, recurso crucial para valorizar o que se está falando. As indicações de dinâmica mantêm-se na maior parte do tempo em contrastes entre $p \mathrm{e}$ f. A intensidade reduzida está associada à timidez ou quando se tem medo da reação do outro, e a intensidade alta é usada em situações de perigo.

Nesta peça podemos falar em jornada psicológica, que começa com a tristeza, passa pelo encantamento e termina em desespero. $O$ intérprete precisa tornar essa jornada perceptiva ao ouvinte. Na poesia há a predominância de vogais claras. 
Lorelei

(Heinrich Heine)

Schnell
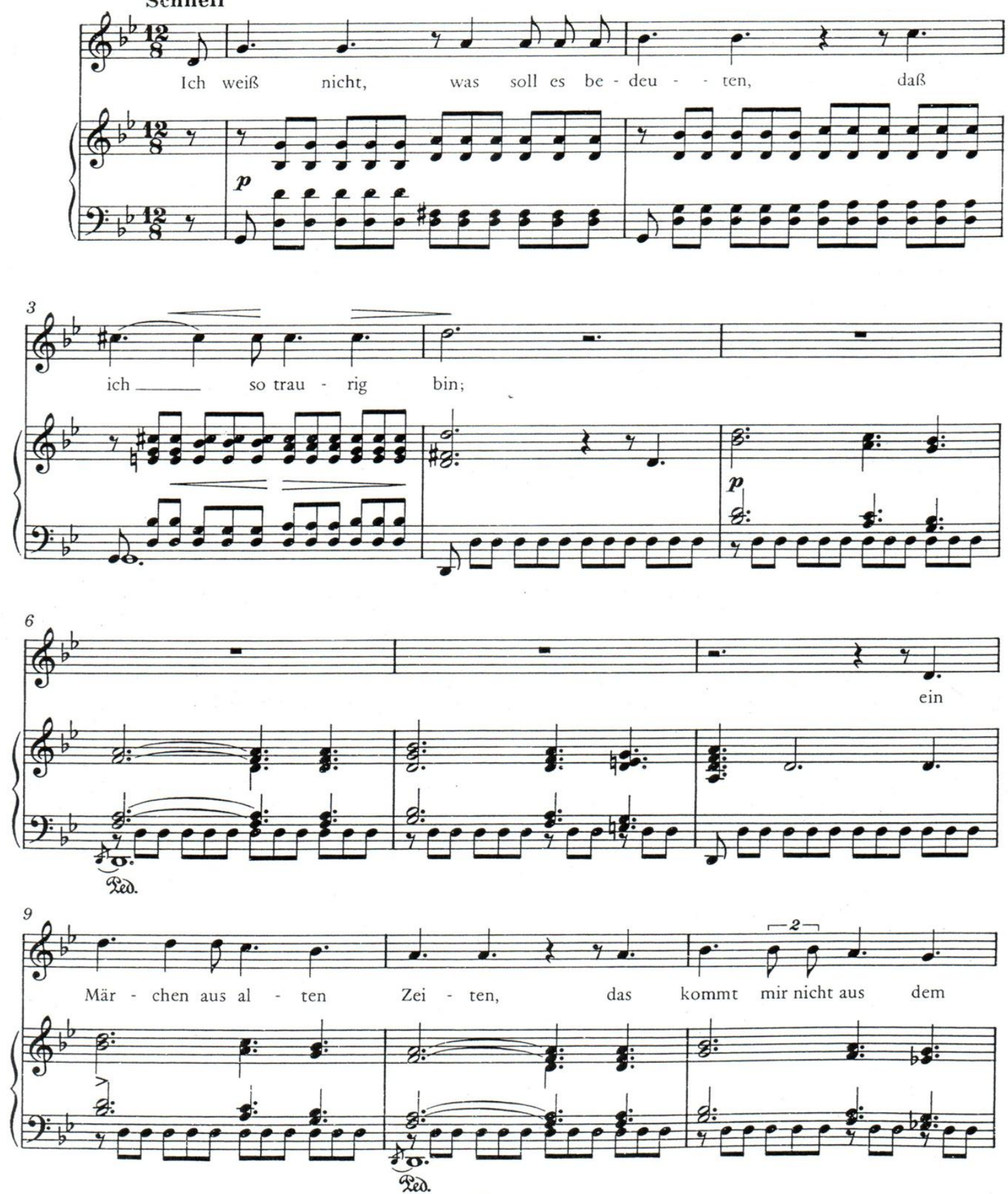
98
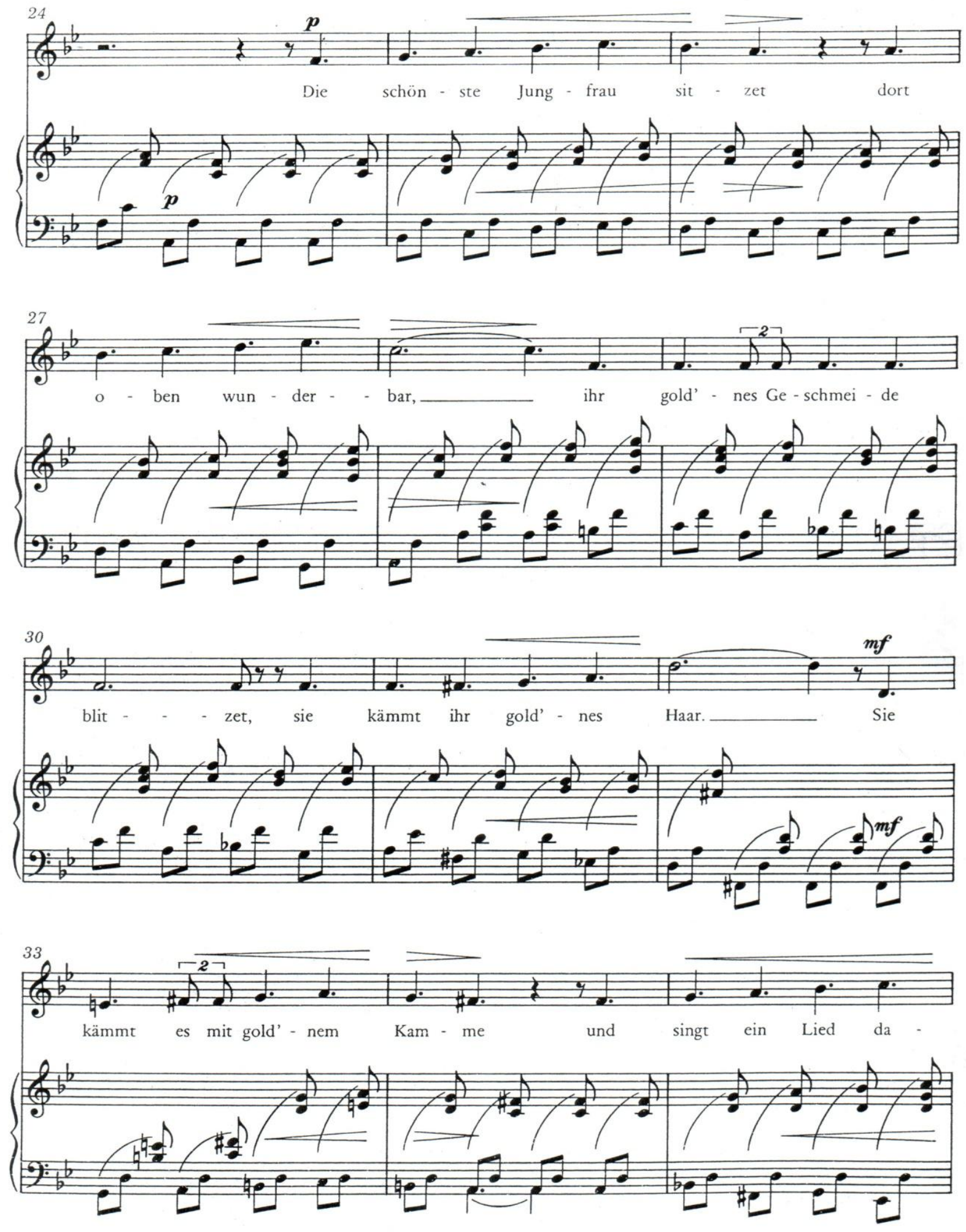

Wb. 2242 

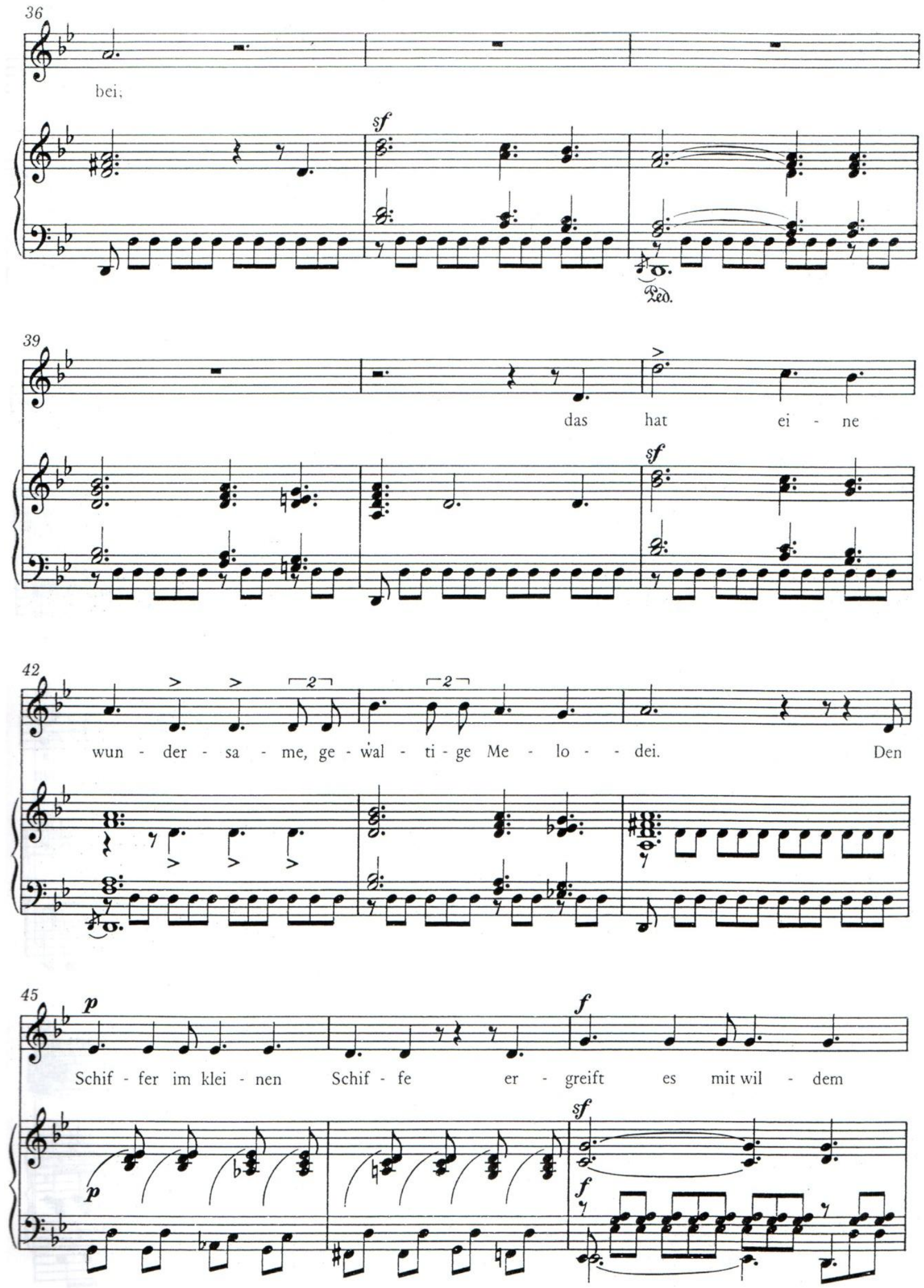

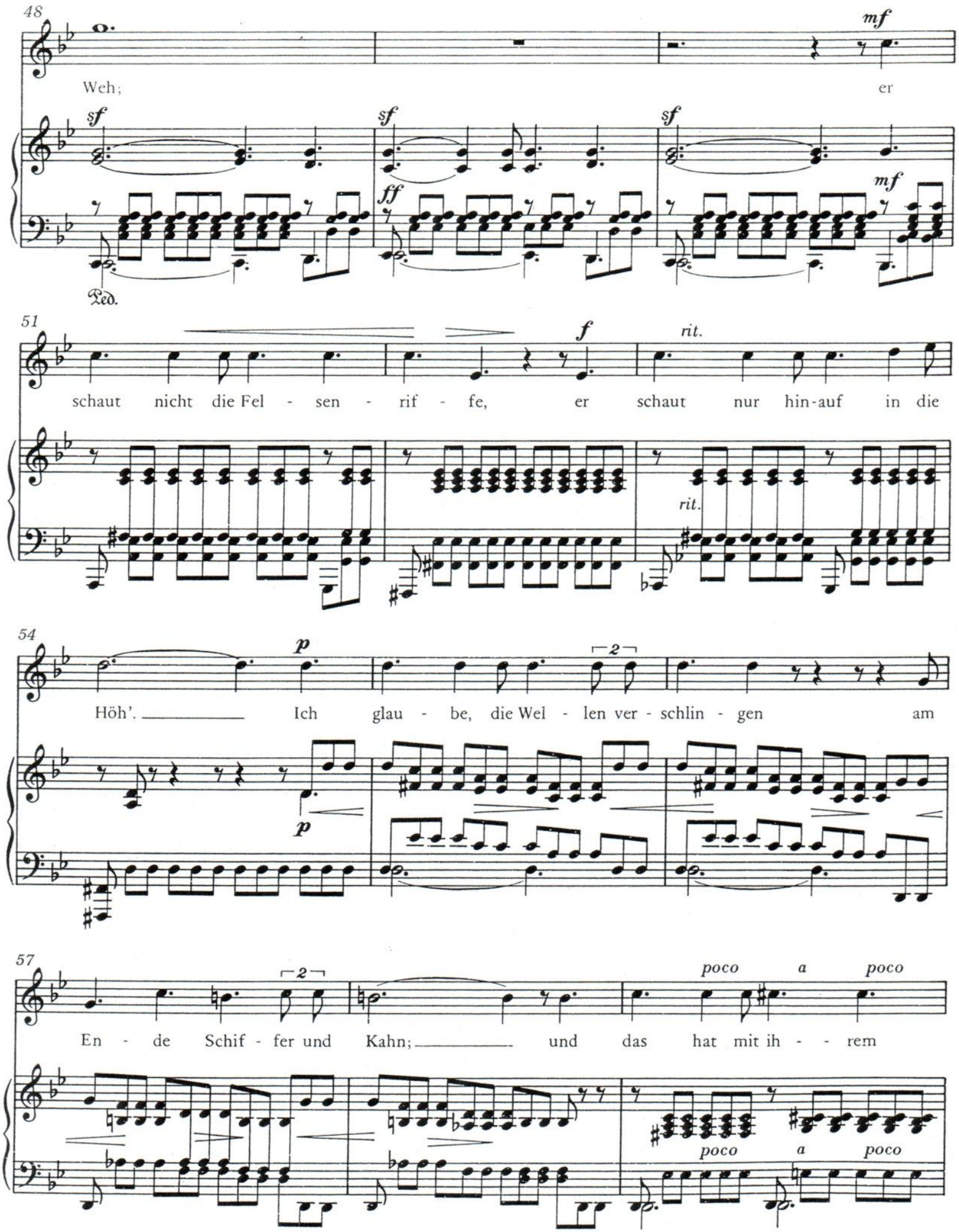

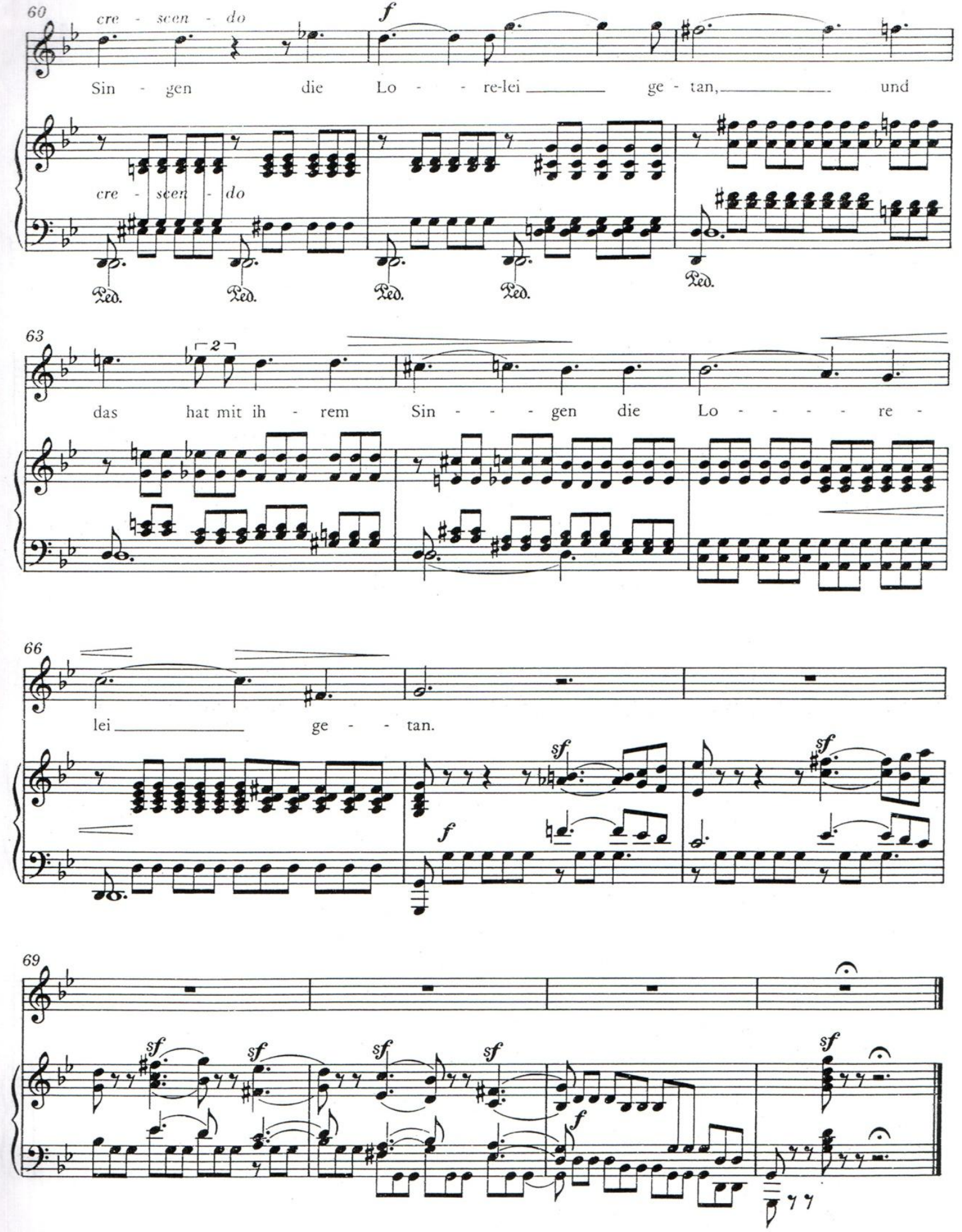

Wb. 2242 


\title{
4.5 O WEH DES SCHEIDENS, DAS ER TAT
}

Dedicatória: "Ao meu amado marido em 8 de junho de 1843."66

\author{
Lorelei \\ Ich hab' in deinem Auge \\ O weh des Scheidens
}

Clara já tinha vivenciado momentos de muita tristeza, nos quais acreditava que Robert não a amava mais. Ela escreve esse Lied alguns meses após uma breve turnê em fevereiro desse mesmo ano. Nesta turnê, Robert cansou-se da posição insignificante que the era imposta - ele era considerado apenas o marido da virtuose. E, em uma decisão repentina, ele deixa Clara sozinha em sua turnê e retorna para Leipzig.

\subsubsection{Análise poética e forma musical}

\section{Oh weh des Scheidens, das er tat Oh dor da despedida, que ele ${ }^{67}$ (Friedrich Rückert) causou}

Oh weh des Scheidens, das er tat, Oh dor da despedida, que ele causou, da er mich ließ im Sehnen! Pois ele me deixou na saudade!

Oh weh des Bittens, wie er bat, Oh dor da súplica, do choro de suas lágrimas,

des Weinens seiner Tränen! como ele implorou!

Er sprach zu mir: Dein Trauern laß! Ele disse-me assim: deixe o luto! und schied doch selbst in Schmerzen. Mesmo assim ele foi embora sofrendo.

\footnotetext{
${ }^{66}$ Este Lied pertence ao mesmo conjunto que o Lied Lorelei, portanto a dedicatória é igual.
}

${ }^{67} \mathrm{O}$ objeto causador da dor é masculino: voz implícita feminina. 
Von seinen Tränen ward ich naß,

daß kühl mir's ward im Herzen.
Com as suas lágrimas eu fiquei encharcada,

E isso esfriou o meu coração.

Rimas: abab / cdcd. É uma poesia diretamente associada à morte; isso fica claro apenas na segunda estrofe. A morte aqui relatada não é a solução, mas sim a causadora da dor. Mesmo com a morte de seu amado, a paixão ou amor da personagem continua existindo. $O$ objeto causador da dor é masculino, deixando implícito que é uma peça para voz feminina.

A forma musical é singular. Podemos separá-la em duas etapas, uma que compreende a primeira estrofe e vai até o compasso 8 e a segunda do compasso 9 ao 22. Nesta parte o piano apresenta o motivo que caracteriza a seção anterior e a melodia vocal introduz uma ideia nova. Nos cinco últimos compassos temos uma coda formada pela fusão das ideias apresentadas nas duas partes.

\subsubsection{Linha melódica vocal}

O estilo é silábico. A primeira estrofe é mais legato e a segunda mais parlato em função das notas repetidas.

A tessitura compreende uma décima primeira (Ré\#3 - Sol4). As frases abrangem uma amplitude de tessitura maior do que nos outros Lieder, na primeira parte são curtas, compreendendo geralmente dois compassos e um verso da poesia, e pareadas - pergunta e resposta. O contorno melódico é marcado por muitos saltos e, no último verso, por notas repetidas. Até o compasso 8 temos a apresentação da primeira estrofe, caracterizada pela dor e desespero da personagem, onde as frases ocupam quase a tessitura de uma oitava.

A frase inicial descendente traduz muito bem a mensagem de decepção, e como termina em uma nota que pede resolução, parece uma pergunta, sustentando a tensão até a frase seguinte, em movimento ascendente. A fermata do compasso 4 adquire uma grande importância expressiva, e nesse momento a personagem tenta 
recuperar $\circ$ fôlego ${ }^{68}$. O compasso 5 apresenta a repetição com uma pequena alteração da primeira frase e a repetição aumenta a ênfase e o caráter dramático. A frase que responde a essa segunda pergunta é parecida com a anterior, mas está em uma região mais aguda e atinge o pico de tessitura da peça. A tensão desse trecho é reforçada pela parte do piano formada por acordes com muitas notas e abrangendo uma ampla tessitura. As frases são curtas, compreendendo geralmente dois compassos e um verso da poesia.

A coda final que se inicia na anacruse do compasso 23 lembra muito a canção final do ciclo Frauenliebe und Leben, e o momento emocional apresentado aqui é semelhante. No ciclo de Schumann a personagem não pode mais viver em função da morte de seu amado, e nesta peça a personagem tem o coração resfriado pela perda de seu amado. O recurso utilizado por Clara - notas repetidas e no final da frase uma nota mais longa - é o mesmo utilizado por seu marido anteriormente.

Persona e para quem está cantando: Essa poesia compreende dois momentos de persona distintos. Na primeira estrofe da poesia a personagem colocase na situação de um narrador, descrevendo a situação ocorrida no passado próximo. A segunda estrofe é mais íntima; parece que a personagem volta no tempo e revive as palavras e as emoções experimentadas naquele momento. A dor e o desespero são deixados de lado momentaneamente. $O$ intérprete precisa reviver esses dois momentos: extremo sofrimento e impotência diante os acontecimentos. É importante frisar que é uma situação vivenciada no passado, portanto o final já é conhecido e não há nenhum momento de esperança.

\subsubsection{Acompanhamento pianístico}

Textura e elementos melódicos: a textura na primeira parte é homofônica. No início da segunda parte a textura é mais rarefeita; mas no compasso 13 começa a ser retomada gradativamente a textura homofônica do início.

68 Em momentos de dor que incluem choro, desespero, é comum ter a capacidade respiratória diminuída, portanto é necessário um tempo maior para respirar, tanto para conseguir conter os soluços do choro como para fazer uma respiração profunda. 
Persona: Nas frases definidas anteriormente como pergunta, o piano é apenas um acompanhamento; mas nas respostas ele dobra a linha do cantor. Talvez a resposta à dúvida da personagem seja tão óbvia que poderia ser respondida por mais de uma pessoa. Na segunda parte, a pergunta feita anteriormente pela voz passa para o piano, mantém esse motivo descendente que expressa decepção, enquanto o cantor revive os momentos em que $\circ$ fato se passou. Esse movimento fica em segundo plano, mas faz com que o ouvinte tenha a certeza de que não existe esperança e que o drama continua. Nos compassos 20 a 22 o piano rouba a cena apresentando o mesmo motivo anterior alterado, de maneira a Ihe atribuir um caráter melancólico ou nostálgico.

\subsubsection{Definições subjetivas}

A indicação inicial é: Sehr langsam und mit tiefster Empfindung - Muito lento com profunda emoção. $O$ intérprete precisa ter o cuidado de eleger um andamento em que the seja possível sustentar a dramaticidade da peça do início ao fim, o que se torna muito difícil se o andamento for lento demais. No momento da mudança do caráter da peça no compasso 9 há apenas a indicação de $p$ e a mudança deve ocorrer já na parte do piano que se inicia com um bloqueio respiratório, que constitui uma defesa a determinadas situações e sentimentos. Anteriormente, nas duas primeiras frases, há uma pausa após a fermata, a ausência dessa fermata mostra que a personagem atingiu o ápice de sua dor. Verificamos a predominância de vogais claras. 
Oh weh des Scheidens, das er tat

(Friedrich Rückert)

Sehr langsam und mit tiefster Empfindung
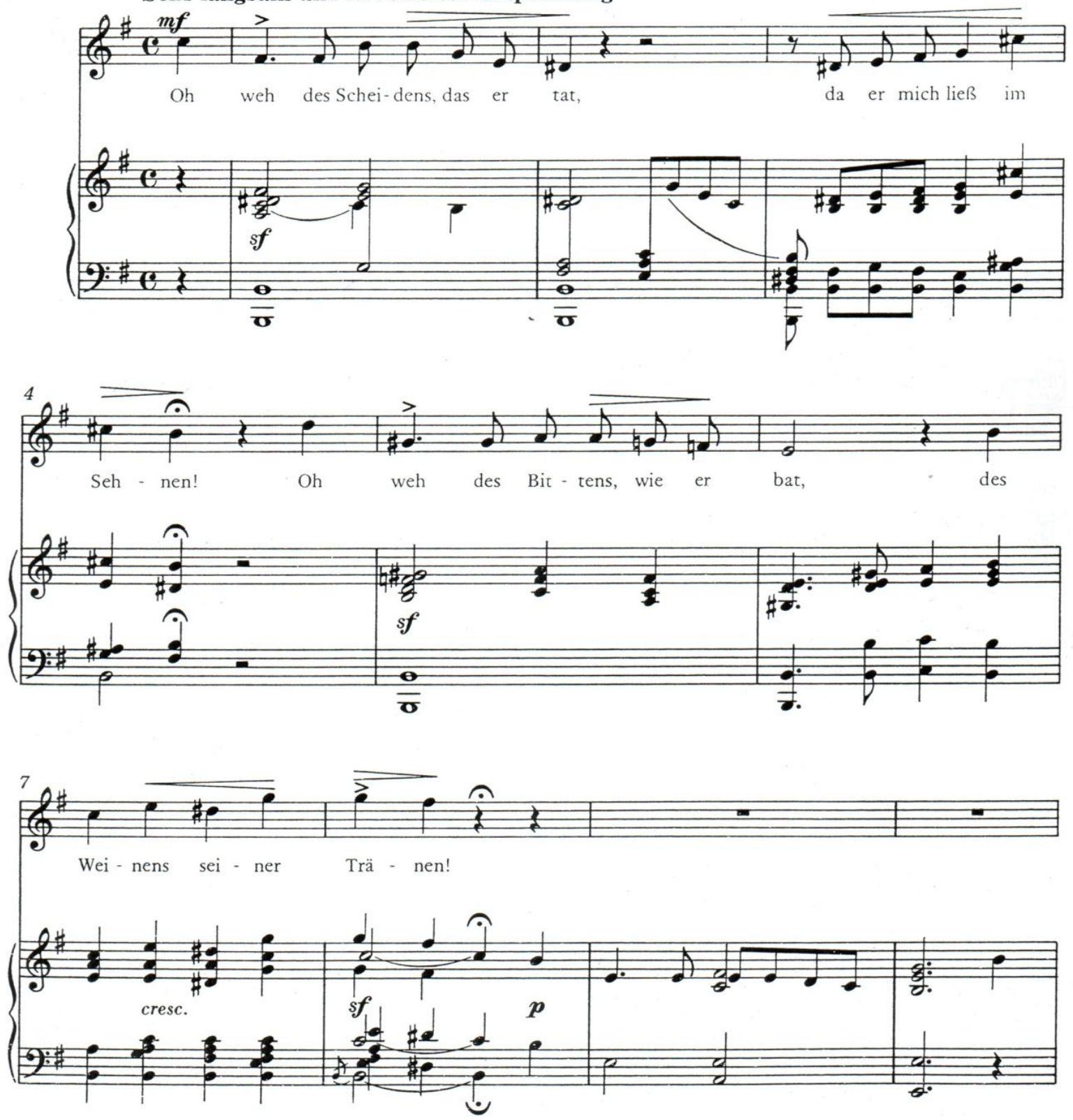

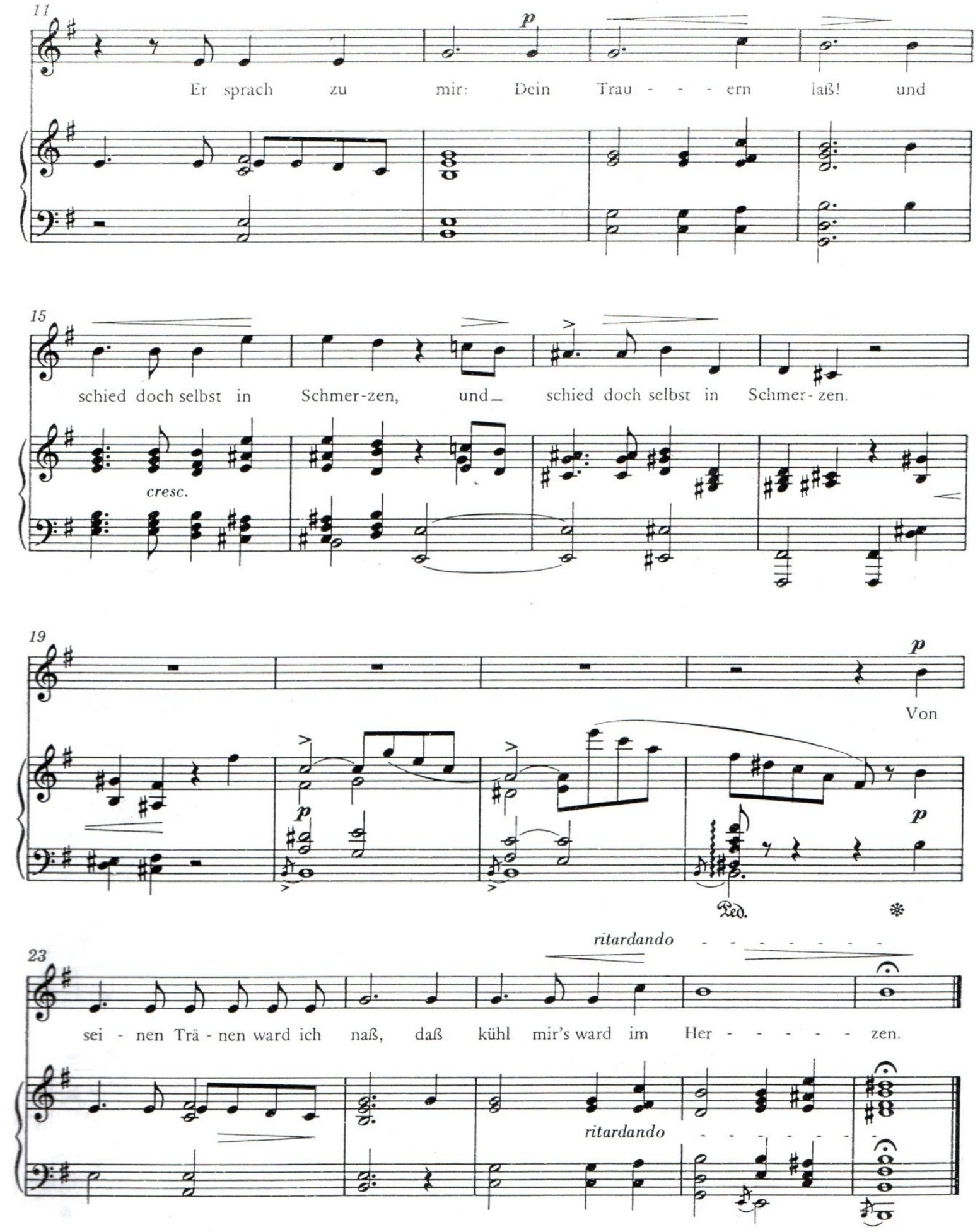

Wb. 2242 


\subsection{BEIM ABSCHIED}

Dedicatória: "Ao autor com saudações amigas, composto por Clara Schumann" junho de 1846.

Dois poemas de Friederike Serre:

Beim Abschied

Mein Stern

Em fevereiro de 1846 nasceu o primeiro filho homem de Clara - Emil. Neste período, Clara estava dando poucos concertos em função dos problemas de saúde de Robert. Encontrava-se ocupada com as obrigações de mãe e esposa; com os encargos financeiros da casa e também precisava dar suporte às atividades de seu marido, que estava muito abalado emocionalmente. Essa era uma das primeiras crises de nervos de Robert.

\subsubsection{Análise poética e forma musical}

\section{Beim Abschied}

(Friederike Serre)

Purpurgluten leuchten ferne,

golden sinkt der lichte Tag,

einzeln werden Silbersterne

an dem Himmelsbogen wach.

Und des Tages Königin

trägt ihr Haupt zum Schlummer hin;

noch ein Gruß, auf Wiedersehn, s'ist kein Abschied, kein Vergehn.

\section{A despedida}

Brasas púrpuras reluzem longínquas,

O dia luminoso afunda dourado,

Solitárias estrelas prateadas

Surgirão no firmamento.

A rainha do dia

Recolhe a sua cabeça para o descanso;

Mais um cumprimento, até mais ver,

Não é uma despedida, não é uma perda.

Sombras cobrem a terra ampla, 
auf den Fluren lagert Nacht.

Armes Herz, nun stille werde,

das der Tag so müd gemacht!

$O$ erscheine lieb und mild

mir im Traume, süßes Bild.

Noch ein Gruß, auf Wiedersehn,

s'ist kein Abschied, kein Vergehn.
Na terra pousa a noite.

Pobre coração, que o dia deixou tão cansado,

Fique tranquilo!

Oh doce figura, apareça para mim de modo amável e suave, em meu sonho.

Mais um cumprimento, até mais ver, Não é uma despedida, não é uma perda.

Ah, escorrem lágrimas quentes, Logo um sentimento saudoso, Logo uma saudade dolorida (envolta por medo),

mir die Brust zerbrechen will.

Nur der Traum führt es zurück, das zu schnell entschwundne Glück.

Noch ein Gruß, auf Wiedersehn, s'ist kein Abschied, kein Vergehn.

Wenn ins Abendrot ich sehe

Und die Sonne sinkt herab, denke ich an all das Wehe, das ich schon bestanden hab. Ach, vielleicht der nächste Morgen hebet alle, alle Sorgen.

Drum getrost, auf Wiedersehn, s'ist kein Abschied, kein Vergehn.
Querem romper meu peito. Apenas o sonho traz de volta,

A felicidade desaparecida tão rapidamente.

Mais um cumprimento, até mais ver, Não é uma despedida, não é uma perda.

Quando eu olho no vermelhão da noite

E o sol se põe,

Eu penso em toda a dor,

Que já superei.

Ah, talvez a próxima manhã,

Levará todas, todas as preocupações.

Deixe estar, até mais ver,

Não é uma despedida, não é uma perda. 
Rimas: ababccdd. Esta poesia também está relacionada à separação. Os dois últimos versos de cada estrofe - um estribilho que é repetido em todas as estrofes e que sofre uma alteração apenas na última - mostram o esforço da personagem ao afirmar que não se trata de uma despedida. Na primeira estrofe, esta ideia realmente não é clara, mas a partir da segunda passamos a encontrar sinais de que a pessoa amada já está morta - "Oh doce figura, apareça para mim de modo amável e suave em meu sonho" - "Apenas o sonho traz de volta a felicidade desaparecida tão rapidamente". Na última estrofe visualizamos indícios de esperança - "Ah, talvez a próxima manhã levará todas, todas as preocupações", mas essa esperança não parece muito concreta, a personagem demonstra incerteza ao utilizar talvez.

Este é um Lied formado por quatro estrofes.

\subsubsection{Linha melódica vocal}

Este Lied é escrito em estilo silábico e legato. A tessitura compreende um intervalo de uma décima segunda (Dó3 a Sol4). Na maior parte do tempo a melodia está centralizada entre Sol3 e Dó4. As frases são de 4 compassos, compreendendo dois versos da poesia, sendo que o primeiro verso é o antecedente e o segundo o consequente. Na terceira frase o antecedente é apresentado pelo piano (anacruse do compasso 10 até início do 11). A última frase do poema é expandida e compreende 8 compassos, quatro de antecedente - dois versos do poema e quatro de consequente - mais outros dois versos. Mas aqui temos a repetição do primeiro verso, pois eles são de métrica inferior aos anteriores.

O ponto culminante, na nota mais aguda, está localizado no compasso 17 . No compasso 15 aparece a indicação de $f$ e no final do compasso 16 um crescendo em direção à nota Sol4 ${ }^{69}$.

Persona e para quem está cantando: Na primeira estrofe temos a impressão de que a poesia está sendo contada por um narrador. No entanto, na metade da

69 Essas indicações de dinâmica nos parecem um exagero ou denotam uma falta de afinidade com a voz. Esse crescendo acontece naturalmente, portanto escrevê-lo pode direcionar o intérprete a um excesso que destoaria do restante da peça. 
segunda estrofe percebemos que a poesia está na primeira pessoa; portanto é contada pela própria personagem. O destinatário passa a ser a própria personagem, que tenta se convencer de que essa não é uma despedida.

\subsubsection{Acompanhamento pianístico}

Textura e elementos melódicos: Textura acordal com dobramento da linha melódica vocal na mão direita. É interessante notar que esse dobramento não acontece nos momentos em que o cantor atinge o ponto culminante da tessitura nos compassos 8 e no segundo tempo do compasso 16 para o 17 . O acompanhamento apresenta um motivo rítmico caracterizado por uma nota pontuada repetida praticamente em toda a peça - acontece com menos frequência e intensidade nos momentos em que a melodia está na parte do piano. Esse motivo mantém a fluidez e o interesse na peça, pois não permite que o tempo seja rallentado - tendência da linha vocal - mantendo o caráter Andante.

Entre as repetições das estrofes existe um breve interlúdio onde é apresentada a melodia da primeira frase do cantor. Este é um momento utilizado para que o cantor possa respirar, além de auxiliar a separação das estrofes.

Nos compassos 15 a 17 Clara demonstra seu conhecimento do instrumento e, para conseguir uma textura mais densa, introduz mais notas nos acordes. Consegue assim uma sonoridade mais cheia, sem exigir esforço do intérprete e proporciona ao cantor uma boa sustentação para atingir a nota aguda.

Persona: É importante definir qual a função da mão direita ao dobrar a linha vocal. Em alguns momentos temos dois personagens vivenciando a mesma situação $^{70}$ - compassos 1 a 4 e 11 a 13, em outros temos um mero suporte para o cantor - anacruse do compasso 6 até o 8 e anacruse de 16 até 20 . Nos momentos em que o piano está sozinho ele assume a persona.

\footnotetext{
${ }^{70}$ Podemos pensar na ideia do duplo, a mesma melodia apresentada por instrumentos de características tão distintas (canto e piano), as duas maneiras de enxergar uma mesma situação.
} 


\subsubsection{Definições subjetivas}

Começa com a indicação de Andante e não há indicação de caráter. Temos indicações de dinâmica tanto na linha vocal como na pianística, entretanto essas marcações não podem ser utilizadas igualmente em todas as estrofes, pois a peça ficaria muito cansativa. Além disso, algumas dessas indicações não seriam necessárias, pois geralmente aparece a indicação de crescendo em direção às notas mais agudas. No entanto, essa é uma característica natural da voz, que se for muito intensificada pode desviar o ouvinte do sentido do texto. Esta peça se mantém numa região central da voz e a utilização de tons graves na fala é normalmente relacionada a situações mais sérias e melancólicas. Nos momentos de tensão ou contenção de sentimentos, utilizamos em nossa fala uma articulação travada movimentação reduzida da mandíbula, que é bastante prejudicial à inteligibilidade do texto, levando o interlocutor a se esforçar para entender o que foi dito. Entretanto, para conseguir transmitir o sentido do texto, o intérprete necessita de uma articulação precisa, soando de forma simples e natural. 
Beim Abschied

(Friederike Serre)
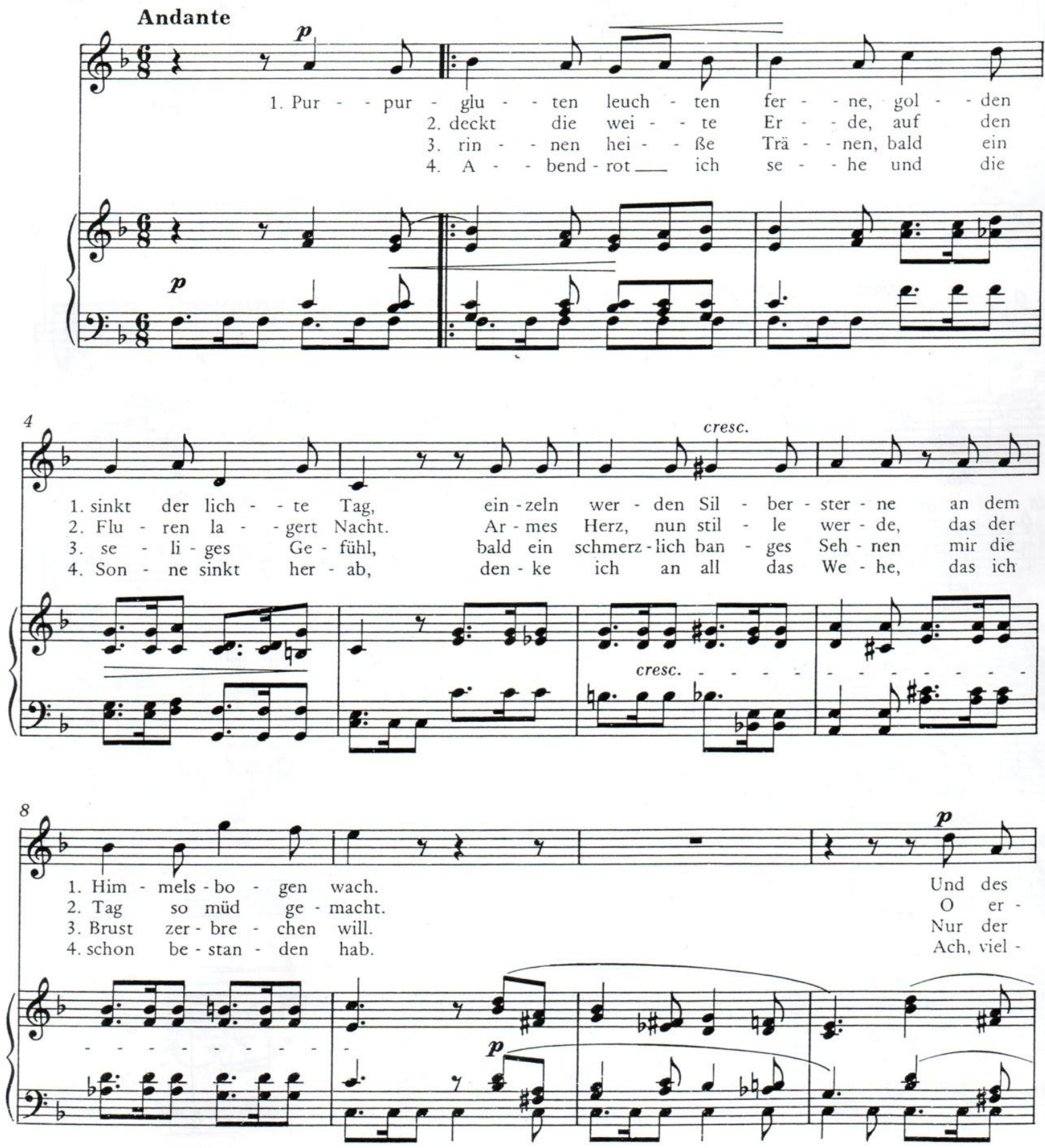

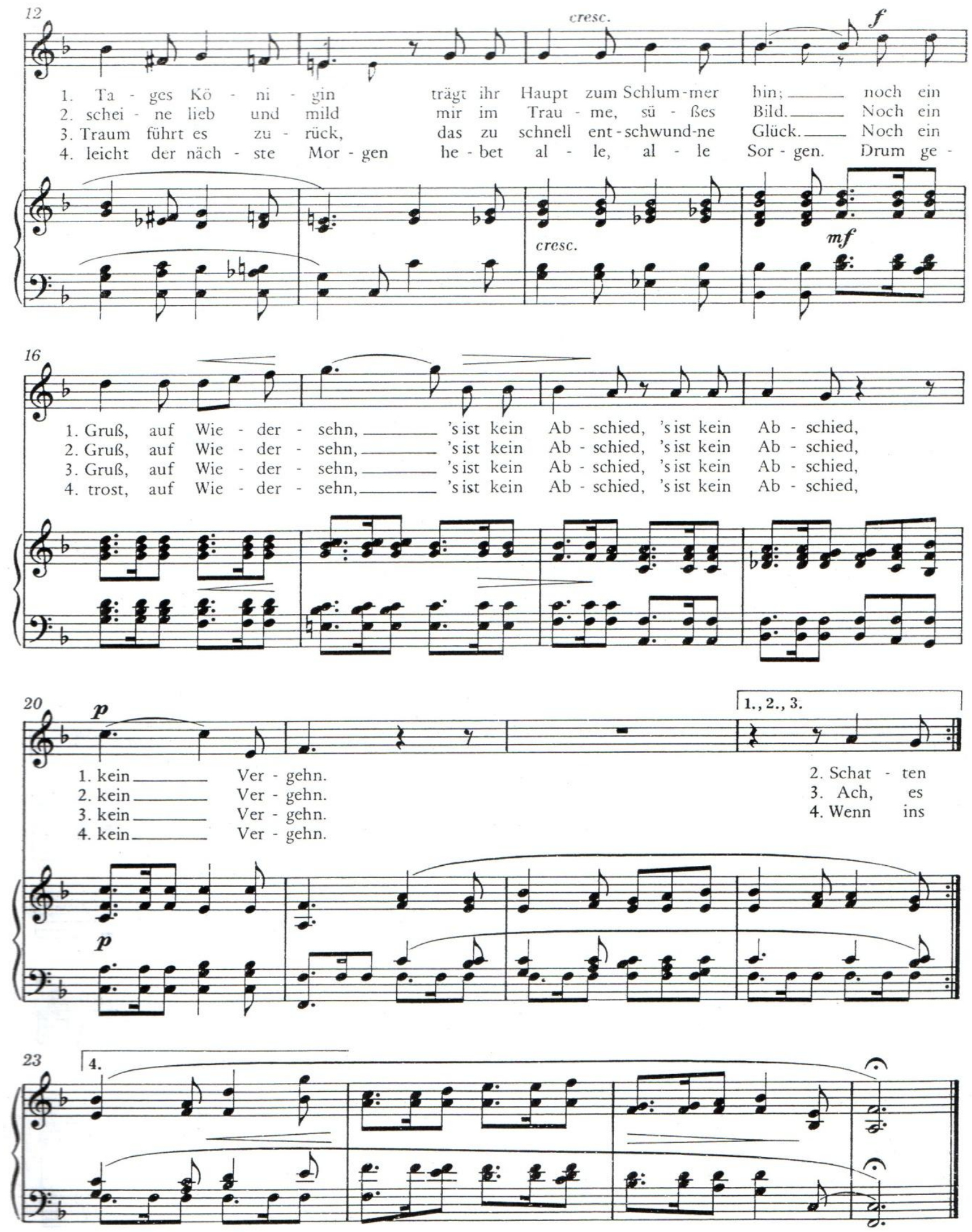


\subsection{DAS VEILCHEN}

Composta em julho de 1853, acredita-se que foi o último Lied escrito por Clara. Não há indicação, na partitura, que tenha sido composto para presentear alguém. Clara dizia não conhecer a composição de Mozart que utilizava essa poesia. Ao dizer isso a Robert provocou risos, mas mesmo assim a composição lhe agradara. Há indícios de que a composição de Mozart esteve presente em um recital seu em março desse mesmo ano.

Em 1852, Clara sofreu um aborto que quase lhe custou a vida. Essa experiência foi muito marcante e provocou mudanças profundas em seu caráter. Ela assume então uma postura diferente em relação ao seu casamento. Neste momento exige um espaço em sua casa para que pudesse dedicar-se aos estudos de piano e à composição. Clara refere-se às composições do ano de 1853 como horas de prazer que desfrutara ao fazer o que realmente gostava. Nesse momento a saúde de Robert estava extremamente abalada, mas mesmo assim Clara planejava outra turnê. Uma nova gravidez a obrigou a mudar seus planos.

\subsubsection{Análise poética e forma musical.}

\section{Das Veilchen}

(Johann Wolfgang Von Goethe)

Ein Veilchen auf der Wiese stand,

gebückt in sich und unbekannt;

es war ein herzig's Veilchen.

Da kam eine junge Schäferin

\section{A violeta}

Era uma vez uma violeta nascida numa campina,

Curvada sobre si mesma, ignorada, Uma violeta sem par!

Veio vindo uma pastora linda, meiga, jovial,

mit leichtem Schritt und munterm De airoso passo e bom coração, Sinn 
daher, daher,

die Wiese her und sang. Contente, cantarolando...

Ach! denkt das Veilchen, wär' ich nur - Ai, geme a flor, pobre de mim, pudesse eu ser,

die schönste Blume der Natur,

A formosa flor do mundo,

ach, nur ein kleines Weilchen,

Por um momento só!

bis mich das Liebchen abgepflückt

Até que viesse o bem amado e me colhesse e, assim colhida

und an dem Busen mattgedrückt!

Junto ao seu peito me apertasse

Ach nur, ach nur

Por um momento apenas,

ein Viertelstündchen lang!

Por um momento só!

Ach! aber ach! das Mädchen kam Veio a pastora e, desastrosa,

und nicht in acht das Veilchen nahm, Não percebendo a humilde flor,

ertrat das arme Veilchen.

Aos pés calcou a pobrezinha,

Es sank und starb und freut sich Tombou, coitada, agonizante, mas, noch: mesmo assim, se alegrava:

Und sterb' ich denn, so sterb' ich - Porque se morro espezinhada ainda doch assim vale morrer,

durch sie, durch sie, zu ihren Füßen doch.
Ainda assim feliz sou eu,

Calcada aos pés da bem amada. ${ }^{71}$

As rimas são irregulares: aabccde. Este poema faz parte do Singspiel Erwin und Elmire -1775. A poesia foi escrita em 1773, Goethe revisou-a algumas vezes, o que não era uma prática frequente desse escritor.

$\mathrm{Na}$ versão original o poema é cantando por Elmire, a heroína rebelde. Ela acredita que o poema foi escrito por Erwin, o herói infeliz que ela trata com frieza. Enquanto ela canta percebe o simbolismo óbvio. A canção comove seu coração e a conduz a demonstrar um pouco de piedade pelo pobre Erwin.

${ }^{71}$ Tradução de Pedro de Almeida Moura (PFROMM, 2005, p.128). 
Existe uma dificuldade cultural para aceitar a violeta como representação de um homem. Em alemão, Veilchen é uma palavra de gênero neutro (em função do diminutivo), podendo representar ambos os sexos.

A violeta é solitária, uma flor modesta e sem pretensões, que desperta afeição e até mesmo piedade. Então uma jovem pastora surge. Ao vermos a palavra Schäferin no poema, encontramos a artificialidade característica dos versos pastorais. Essa pastora é desatenta e descuidada. A pobre violeta desejava ser, por um momento, a flor mais bonita da natureza, até que sua amada chegasse para colhê-la e apertá-la junto ao peito até murchar. No entanto, a moça não presta atenção e acaba por pisá-la. Ela tomba e morre e ainda se alegra por ter morrido aos seus pés.

Forma ternária $A B A^{\prime}$ coda. A seção $A$ vai até o compasso 20 , a seção $B$ se inicia na anacruse de 21 e vai até o compasso 32. Na anacruse de 33 começa a seção A' e da anacruse do compasso 48 até o final temos uma coda.

\subsubsection{Linha melódica vocal}

O estilo é silábico e predominantemente parlato. Não temos a predominância de notas repetidas comuns ao estilo parlato, mas o andamento, os inúmeros saltos e principalmente a leveza da poesia não combinam com um estilo muito legato.

A tessitura é de uma décima (Mi3 até Sol4). O contorno melódico realiza muitos zigue-zagues com a presença constante de saltos pequenos. As frases são longas, compreendendo mais de dois versos da poesia, o que traz algumas dificuldades ao cantor relacionadas à respiração. A composição de Clara começa com um caráter jocoso, mas ela brinca com a tonalidade maior e menor provocando uma incerteza no público em relação ao final da história, como se fosse um prenúncio de que a história não terá um final feliz.

Persona e para quem está cantando: A poesia narra um amor platônico, a alegria pelo fato da morte ser causada pela amada. Mais uma vez a morte surge como solução para o amor não correspondido. O cantor é o narrador dessa história, e em alguns momentos se posiciona na figura da violeta, contando seus desejos em primeira pessoa. O destinatário é o público. 


\subsubsection{Acompanhamento pianístico}

Textura e elementos melódicos: Na parte A temos um acompanhamento que visualmente assemelha-se a um baixo contínuo, ou seja, um baixo na mão esquerda fazendo as fundamentais da harmonia, que são preenchidas pela mão direita. Como se trata de um allegro, não há muito espaço para intervenções do intérprete, que está realizando o contínuo. Nos compassos 17 a 19 temos uma ornamentação escrita, um grande arpejo ascendente que encerra a seção $A$. Esse é um movimento melódico frequente nas realizações de baixo contínuo. O fato de Clara utilizar uma riqueza maior de articulação, ao invés de dinâmica, também nos remete à escrita barroca. A intenção da compositora parece realmente a de recriar o ambiente pastoral. Essa é uma poesia do início do romantismo, assim não encontramos a densidade emocional vista em outros poemas. É interessante notar que o intérprete deve tocar essa peça como se estivesse improvisando.

Persona: a parte do piano é um suporte harmônico escrito de modo a ambientar a poesia. A voz superior da mão direita dobra a linha do cantor. Na seção $B$, a mão esquerda do piano narra a história juntamente com o cantor. No entanto, o piano não assume a persona.

\subsubsection{Definições subjetivas}

Não há nesse Lied nenhuma indicação de caráter ou andamento. O intérprete tem a liberdade de defini-las, no entanto, é preciso cuidado ao escolher o andamento, pois é importante manter o caráter jocoso da poesia. Para esta decisão é necessário refletir em questões relacionadas a fala, pois ao fazê-lo rapidamente pode-se transmitir ansiedade, egocentrismo e sensação de que se quer omitir fatos. Ao contrário, ao se falar lentamente transmite-se a sensação de falta de organização de ideias ou lentidão de pensamento. Como a personagem é um narrador, a articulação deve ser precisa para demonstrar o interesse em contar essa história. 
A peça começa com a indicação de $p$ e encontramos em seu decorrer, crescendi e decrescendi. No início de cada seção a indicação de $p$ reaparece. A intensidade reduzida está associada à timidez ou ao medo da reação do outro e nossa protagonista vivencia esses sentimentos inúmeras vezes.

Das Veilchen

(Johann Wolfgang von Goethe)
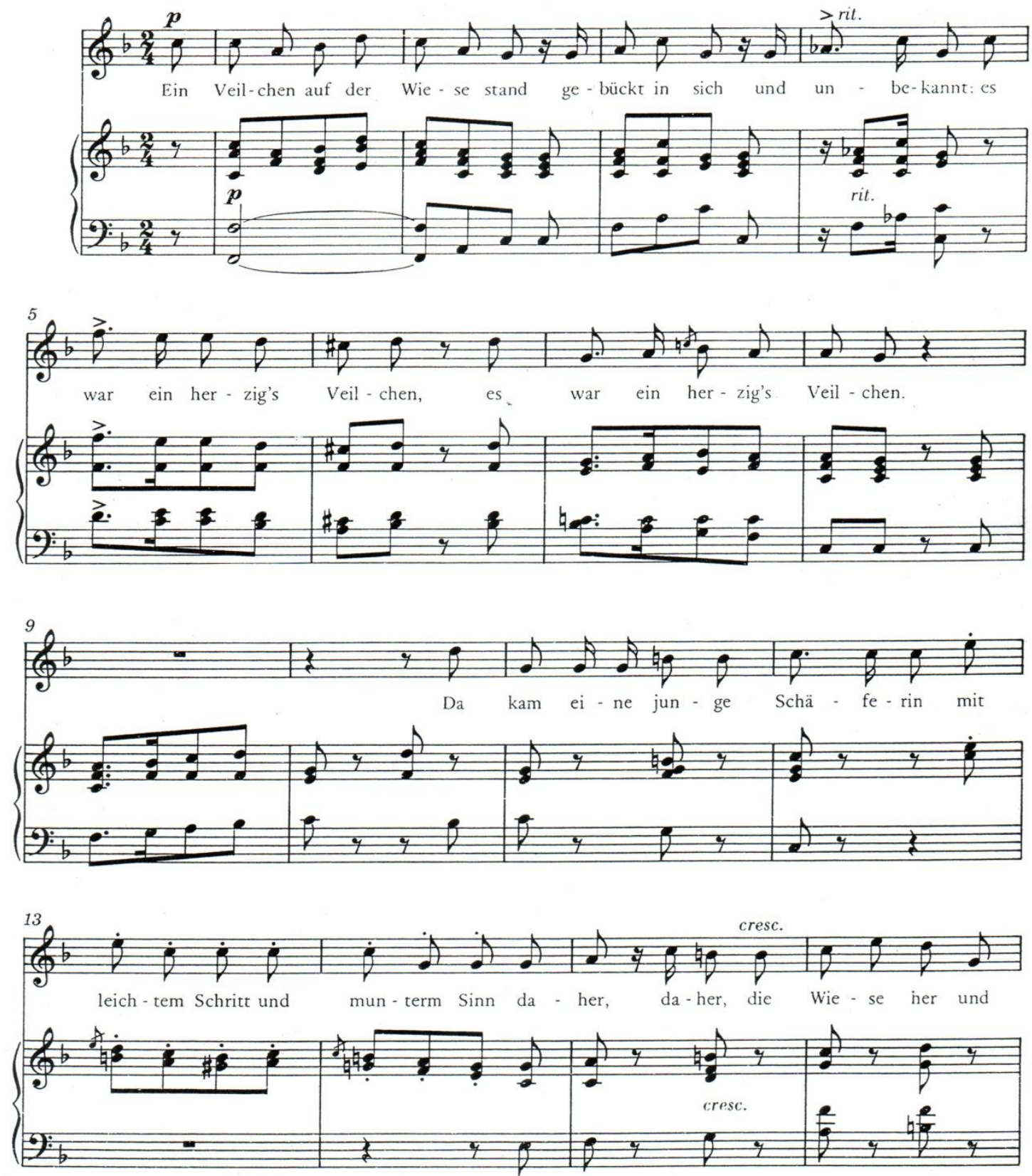

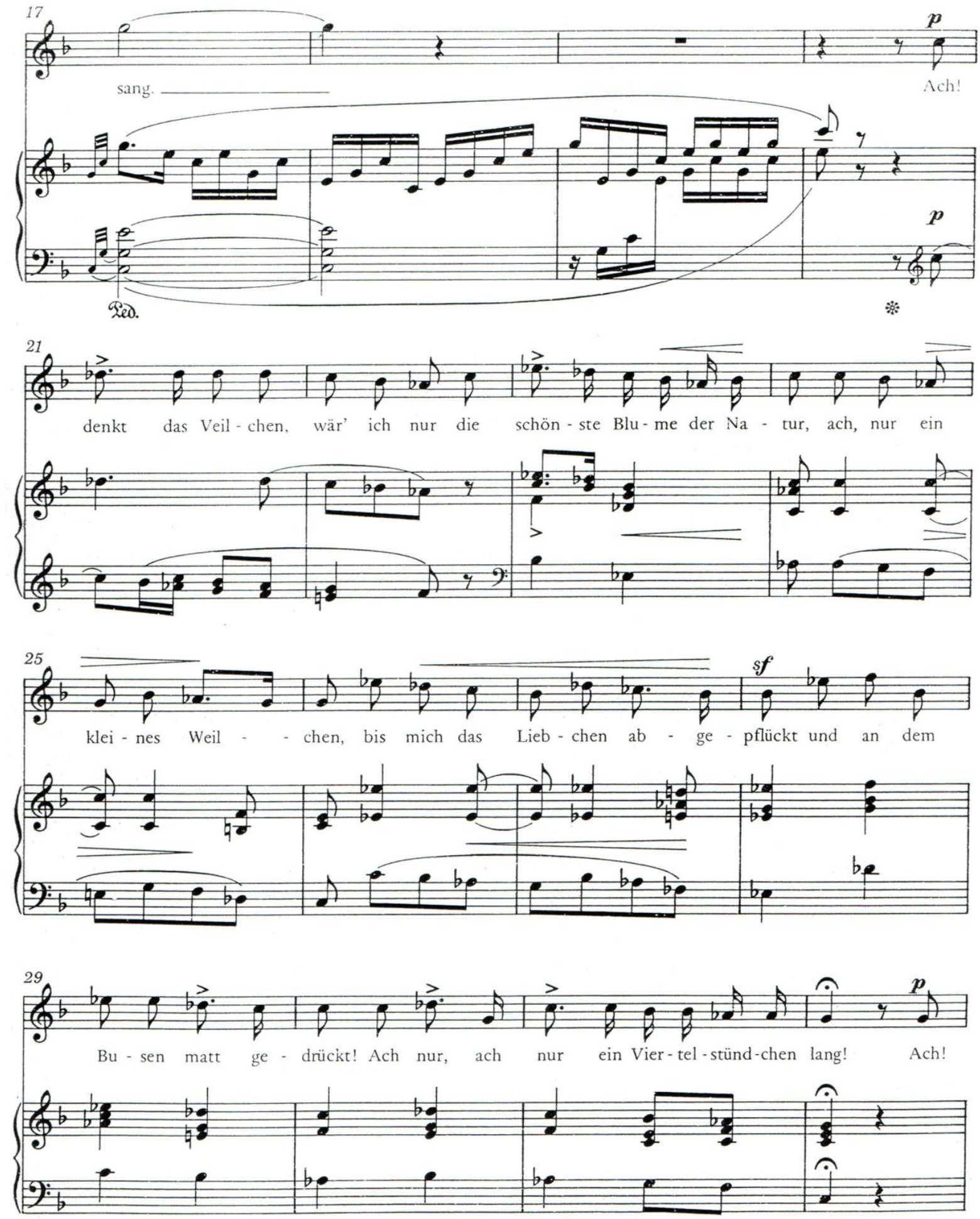

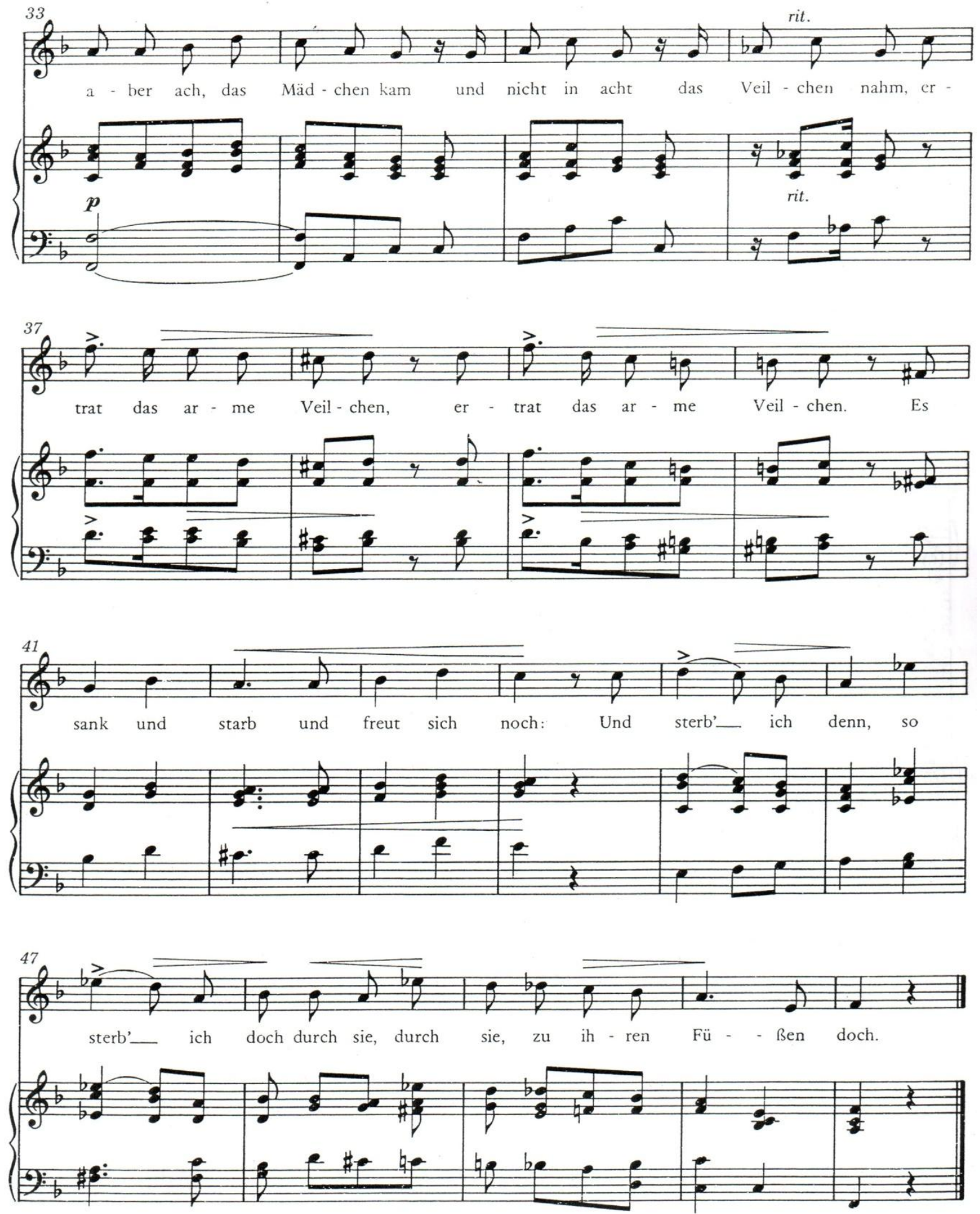
5 CONSIDERAÇÕES FINAIS 
Ao compararmos os Lieder de Clara com os de Robert percebemos que as composições dela são mais conservadoras do que as de seu marido. Talvez fosse muita pretensão esperar que as composições de uma mulher do século XIX - época em que a mulher deveria manter um comportamento modesto e evitar as atividades criativas - fossem um trabalho composicional mais inovador do que as composições de Robert Schumann, que depois dos 18 anos dedicou todos os seus esforços à composição e foi o responsável por inúmeras modificações na estética musical.

Os fatores sociais não afetaram as ambições de Clara como concertista. Não há dúvidas sobre sua importância como performer. Entretanto, as convenções sociais traziam-Ihe desconforto em relação à composição. Julgava ser possuidora de talento criativo, mas em contrapartida não acreditava que poderia ser a primeira mulher a compor. Mesmo alternando momentos de dúvida em relação às suas habilidades composicionais, perseverou e continuou compondo durante todo o período em que seu marido viveu ${ }^{72}$.

Robert acreditava no talento composicional de Clara, escrevendo no diário do casal em 17 de fevereiro de 1843:

Clara tem escrito um número de pequenas peças que mostram uma
invenção que ela nunca tinha atingido antes. Mas ter filhos e um
marido que está sempre nos reinos da imaginação não compatível
com a composição. Ela não pode trabalhar regularmente e estou
sempre incomodado em pensar quantas ideias profundas são
perdidas porque ela não pode trabalhá-las. Mas Clara mesma sabe
que sua ocupação principal é ser mãe, e eu acredito que ela é feliz
com as circunstâncias e que não gostaria de mudá-las (SCHUMANN,
R. apud REICH, 2001, p.215).

Seus trabalhos demonstram sua individualidade composicional. Clara sempre foi acima de tudo uma intérprete, sua formação foi direcionada nesse sentido. Ela não teve o poder nem a ambição para ser um dos líderes do período romântico, mas sempre foi aceita como um deles.

Clara escreveu um total de 23 Lieder durante os 13 anos de casamento com Robert. Onze dessas composições foram presentes para Robert, duas delas foram

\footnotetext{
${ }^{72}$ Uma das razões para Clara ter parado de compor após a morte de seu marido é o grande número de responsabilidades como mãe e musicista.
} 
presentes para o amigo Friederike Serre e utilizavam seus poemas. E os Lieder escritos em 1853, seis Lieder opus 23 e Das Veilchen não foram escritos para presentear ninguém, eram composições para ela mesma.

De seus 23 Lieder de maturidade musical, 15 foram publicados rapidamente com número de opus (12, 13 e 23), um foi publicado individualmente na Alemanha Am Strande - e um teve uma publicação com o texto traduzido para o inglês - Mein Stern / O Thou my star - na ocasião de abertura de um hospital em Londres. As outras seis foram publicadas tardiamente, apenas em 1992.

É impossível saber a razão pela qual essas composições demoraram tanto tempo para ser publicadas, e não é possível afirmar se essa foi uma decisão da própria Clara ou de Robert. Com exceção de Das Veilchen, essas composições foram escritas durante os seis primeiros anos de casamento, período em que Robert estava avidamente envolvido em conseguir e organizar a edição das composições de Clara.

Clara começou a escreveu esses Lieder em 1840, imediatamente após o seu marido ter o ano mais prolífico desse gênero. Pensando dessa maneira é muito fácil entender a razão do intimidamento de Clara perante este gênero, mas algumas hipóteses nos parecem bastante pertinentes.

Verificamos algumas características peculiares nessas composições que podem justificar o destino dado a essas peças. Algumas são trabalhos intensamente pessoais e, talvez, fossem pessoais demais para serem publicadas. Dos três primeiros Lieder que escreveu para Robert, apenas Volkslied não foi publicado. As duas peças publicadas são claramente Lieder de amor, enquanto Volkslied descreve a destruição de um casal apaixonado que fugiu de casa secretamente. É uma peça de grande dramaticidade e beleza. Relembraria, entretanto, ao público a briga judicial de Robert e Clara contra Wieck, para conquistar o direito de se casar sem o seu consentimento. Possivelmente o casal não teve interesse em publicar uma composição que demonstrava insegurança em relação ao futuro.

Uma situação semelhante aconteceu com os presentes do ano de 1843, sendo que a única peça editada foi a que narra uma história de amor não problemática. Nessa ocasião as peças não publicadas foram Lorelei e $O$ weh des Scheidens, peças densas e escuras que contém situações de fatalidade e desespero. 
Der Abendstern, Die gute Nacht e Beim Abschied são canções relacionadas à separação e à saudade. Der Abendstern é uma composição de juventude, uma melodia bonita, mas uma composição muito simples, que não demonstrava a maturidade musical de Clara. E Das Veilchen narra uma história de amor onde um dos amantes acaba esmagado pelos pés de sua amada.

Embora nos deparemos com algumas temáticas mais densas e escuras características do período romântico - entre os Lieder publicados, a maior parte das peças editadas são evocações positivas de amor e de natureza. As não publicadas expressam tristeza e o lado pessimista da personalidade de Clara.

Ao observarmos as partes de piano percebemos que foram compostas mais por uma pianista do que por uma compositora. Elas são extremamente apropriadas aos recursos do instrumento e algumas exigem o virtuosismo técnico que Clara dominava tão bem. Nesse aspecto composicional Clara difere fortemente de Robert, cujas composições trazem dificuldades aos intérpretes pela inadequação às características físicas do instrumento.

Nas linhas vocais, Clara tem o cuidado de utilizar uma tessitura confortável e um contorno melódico simples que, aparentemente, não traz grandes dificuldades ao intérprete. No entanto, por ser muito transparente, faz com que todas as dificuldades técnicas se evidenciem.

O acompanhamento das peças não publicadas também mostra uma faceta de Clara que não é frequentemente vista em seus outros trabalhos. Eles tendem a ser menos virtuosísticos e são mais expressivamente românticos na representação do texto e estado de espírito. Apenas Lorelei apresenta a bravura dos acompanhamentos típicos dos Lieder publicados e dos trabalhos para piano de Clara.

Talvez preocupações com possíveis comparações possam ter influenciado a decisão de editar ou não essas peças. Clara tinha consciência das comparações profissionais e evitava competições diretas com os outros ${ }^{73}$. Provavelmente não gostasse de publicar trabalhos que pudessem ser comparados com obras já editadas de Robert ou de outros compositores. Das Veilchen já tinha sido musicado anteriormente por Mozart. As notas repetidas de Lorelei nos remetem a Erkönig e Robert já tinha editado a lenda da Lorelei em seu Waldesgespräch de Eichendorf,

\footnotetext{
${ }^{73}$ Ela desencorajou seu filho Felix a seguir na música por medo de que as comparações com o seu pai nunca lhe fossem favoráveis.
} 
em seu Liederkreis. Robert compôs um Lied utilizando a poesia Volkslied, depois de ganhar a peça assim intitulada. Die gute Nacht tem um poslúdio final que é uma verdadeira homenagem a Robert, uma citação de sua obra ${ }^{74}$, e além disso, havia escrito uma obra para coro utilizando essa mesma poesia.

Essas são provavelmente apenas suposições que jamais poderão ser confirmadas. As análises e gravações efetuadas evidenciaram as qualidades dessas composições e suas ligações com as temáticas românticas.

Esperamos que este trabalho possa contribuir para que essas peças não continuem esquecidas pelos intérpretes.

${ }^{74}$ Schumann nutria grande preocupação com a posteridade. Tinha o cuidado de escrever diários e guardá-los, organizando todos os seus manuscritos. Talvez percebesse que a publicação dessa composição que utilizava recursos muito frequentes em suas composições pudesse denegrir a imagem de sua esposa como compositora, deixando-a a sua sombra. 


\section{REFERÊNCIAS}




\section{REFERÊNCIAS}

BECHARA, E. Moderna gramática portuguesa. Rio de Janeiro: Lucerna, $37^{a}$ ed., 2001.

BIANCHI, W. Interpretação Musical baseada na Lei do Universo. São Paulo: Editor autor, 2003.

BRODY, E. \& FOWKES, R. A. The German Lied and its Poetry. New York: New York University Press, 1971.

CANDÉ, R. História Universal da Música. São Paulo: Martins Fontes Editora, vol.2, 1994.

DICIONÁRIO Houaiss da Língua Portuguesa. Editora Objetiva: Online, 2009.

DIESKAU D. F. Hablan los sonidos, suena las palabras - Historia e interpretacion del canto. Madrid: Ediciones Turner, Traducido por Carmen Schad, 1990.

GIRON, L. A. As composições Autocríticas de Clara Schumann. Disponível em: http://www.reocities.com/Vienna/8179/clar.html Acesso em: 30 de jul. 2011.

GOLDSTEIN N. Versos, sons, ritmos. São Paulo: Série Princípios, 13ª . ed. 2000.

GORRELL, L. The Nineteenth-Century German Lied. Oregon: Amadeus Press, 1993.

GROUT, D. J. \& PALISCA, C. V. História da Música Ocidental. Lisboa: Gradiva, 4ed. Tradução de Ana Luísa Faria, 2007.

HALLMARK, R. German Lieder in the Nineteenth Century. New York: Routledge, 2010.

LEPRONT, C. Clara Schumann. São Paulo: Martins Fontes Editora, 1990.

LIMA, S. F. O. Conceitos e teoria musical básica. In: Um Sistema para Transposição Automática de Sequências MIDI baseada em alcance Vocal. Uberlândia: Dissertação (Mestrado em Ciências) - Universidade Federal de Uberlândia, 2006. Disponível em:

<http://www.bdtd.ufu.br/tde arquivos/11/TDE-2006-06-02T090138Z-

229/Publico/SFOLima1DISSPRT.pdf> Acesso em: 30 Jul. 2011.

MAGNANTI, C. O que se faz com a linguagem verbal? In: Revista Linguagem em Discurso, volume 1, número 1, jul./dez. 2001.

MEYER L. B. La emoción y el significado en la música. Madrid: Alianza Música, Versión española de José Luis Turina, 2001. 
NORDERVAL, K. The unpublished songs of Clara Schumann: a scholarly edition/ by Kristin Norderval. New York: Tese (Doutorado) - Manhattan School of Music, 1993.

PARSON, J. The Cambridge Companion to the Lied. Cambridge: Cambridge University Press, 2004.

NETTO, S. Goethe Poesias escolhidas. São Paulo: Editora Átomo, $2^{\mathrm{a}}$ ed., 2005.

QUADROS, C. L. Lied: Poesia, Filosofia e Música, 2008, p.1 Disponível em: http://www.usp.br/siicusp/Resumos/16Siicusp/1268.pdf Acesso em: 30 Jul. 2011.

REICH, N. Clara Schumann: The artist and the Woman. New York: Cornell University Press, (revised edition), 2001.

ROSEN, C. A Geração Romântica. São Paulo: Edusp, Tradução de Eduardo Seicman, 2000.

SAMUEL, C. Clara Schumann Secretos de una Pasión. Buenos Aires: El Ateneo, Traducción de Silvia Kot, 2007.

SCHUMANN, C. Sämtliche Lieder für Singstimme und Klavier. Prefácio de DRAHEIM; HÖFT. Leipzig: Breitkopf \&Härtel Wiedsbaden, Band I, 1990.

Sämtliche Lieder für Singstimme und Klavier. Prefácio de DRAHEIM; HÖFT. Leipzig: Breitkopf \&Härtel Wiedsbaden, Band II, 1992.

SCHUMANN, R. Sämtliche Lieder für eine Singstimme MIT Klavierbegleitung. Leipzig: C. F. Peters Wiedsbaden, Band I, s.d.

SCHUMANN, E. Schumann: Vida Romântica - Inquietudes artísticas - Diário Íntimo. Buenos Aires: Ediciones SUMA, s.d.

SCHOENBERG, A. Fundamentos da composição musical. São Paulo: Edusp, 1991.

SILVA, E. M. A. M. Clara Schumann - Compositora x Mulher de Compositor. São Paulo: Ficções Editora, 2011.

SMEED, J. W. German Song and its Poetry 1740-1900. New York: Croom Helm Ltd, 1987.

SOUZA R. C. Nepomuceno e a gênese da canção de câmara brasileira. Música em perspectiva, v.3 n.1, março 2010, p. 33-53. Disponível em: <http://ojs.c3sl.ufpr.br/ojs2/index.php/musica/article/viewFile/20979/13898> Acesso em: 30 Jul. 2011.

STEEGMANN. M. Clara Schumann. London: Haus Publishing, 2004. 
STEIN, J.M. Poem and Music in the German Lied from Gluck to Hugo Wolf. Massachusetts: Harvard University Press, 1971.

STEIN, D.; SPILLMAN, R. Poetry into Song - Performance and Analysis of Lieder. New York: Oxford University Press, 1996.

The New Grove Dictionary of Music and Musicians. New York: Oxford University Press, 2001.

THYM, J. Of Poetry and Song - Approaches to the Nineteenth- Century Lied. New York: University of Rochester Press, 2010.

TRAGTENBERG, L. Contraponto uma arte de compor. São Paulo: Edusp, 2004.

ZANI NETTO, A. Schumann: as sonatas op. 11 e op. 22 para piano. São Paulo: Dissertação (Mestrado em Artes) - Escola de Comunicações e Artes, Universidade de São Paulo, São Paulo, 1982.

Florestan e Eusebius: por que? São Paulo: Tese (Doutorado em Artes) - Escola de Comunicações e Artes, Universidade de São Paulo, São Paulo, 1988. 
ANEXO I 


\section{Der Abendstern}

Erstdruck
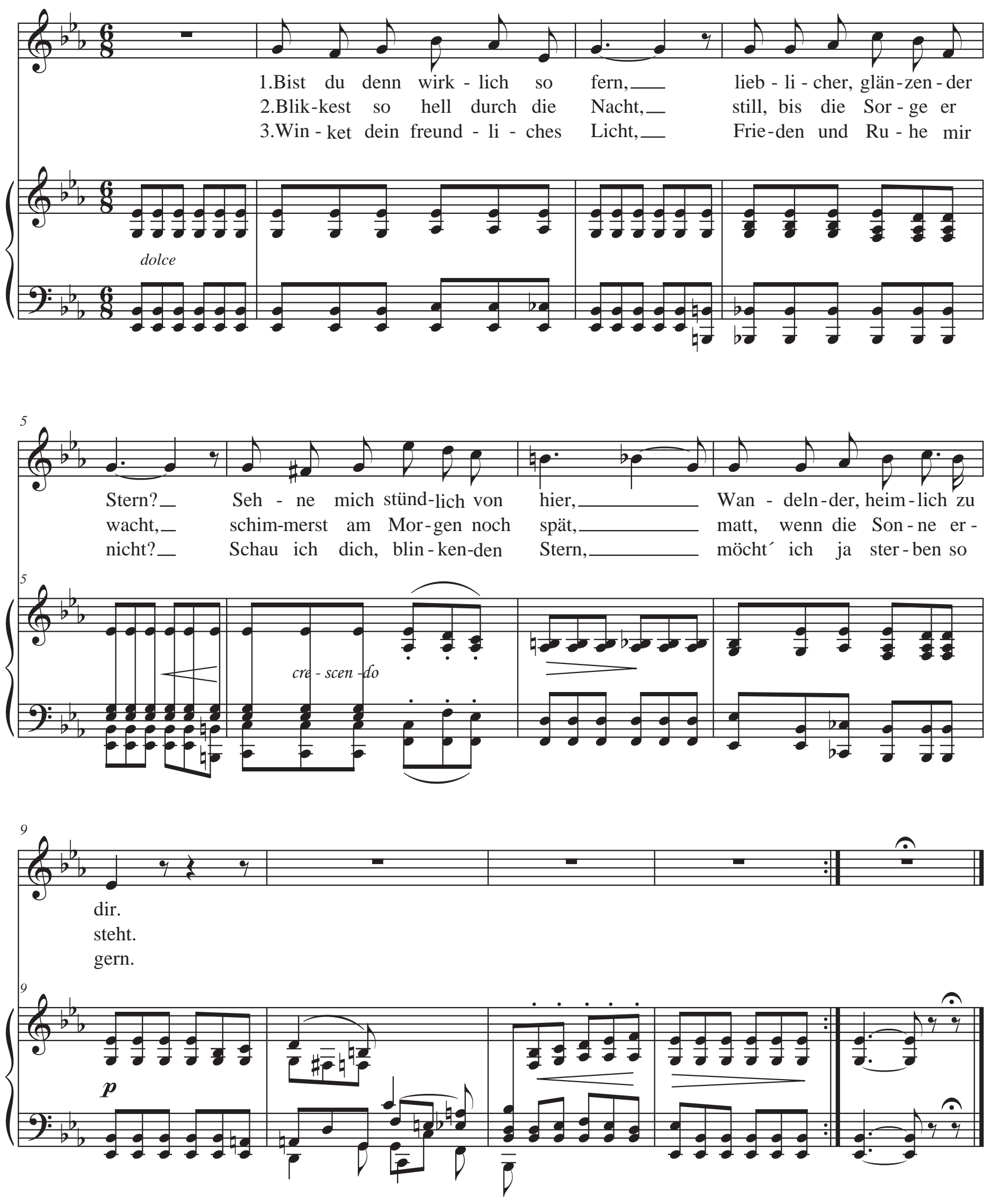


\section{Die gute Nacht, die ich dir sag}

(Friedrich Rückert)

Erstdruck
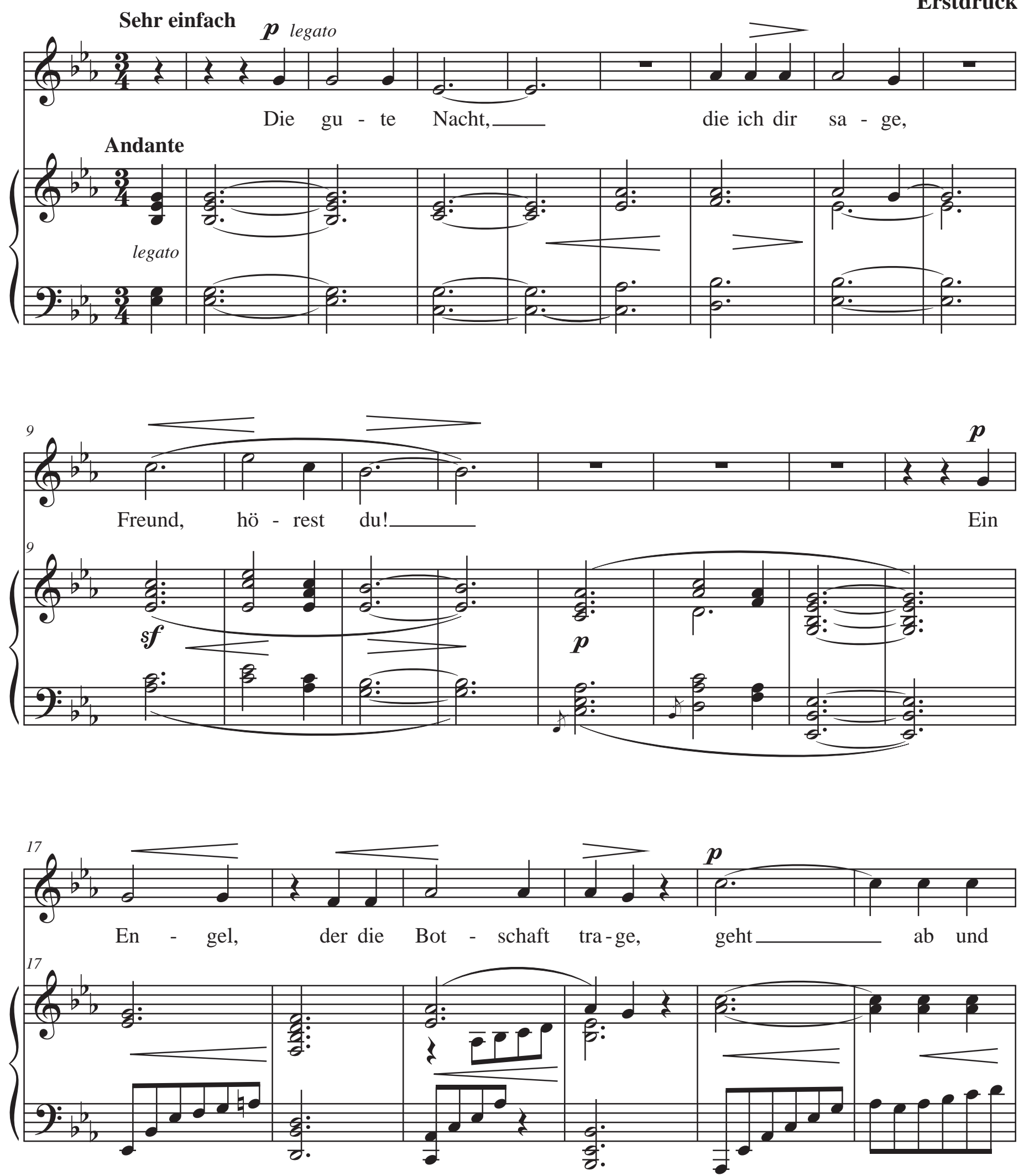
$\int^{23}$

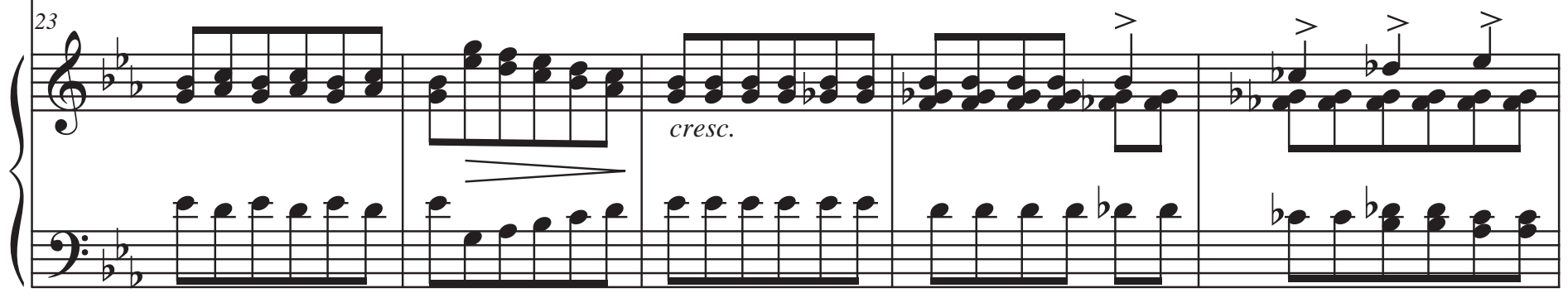

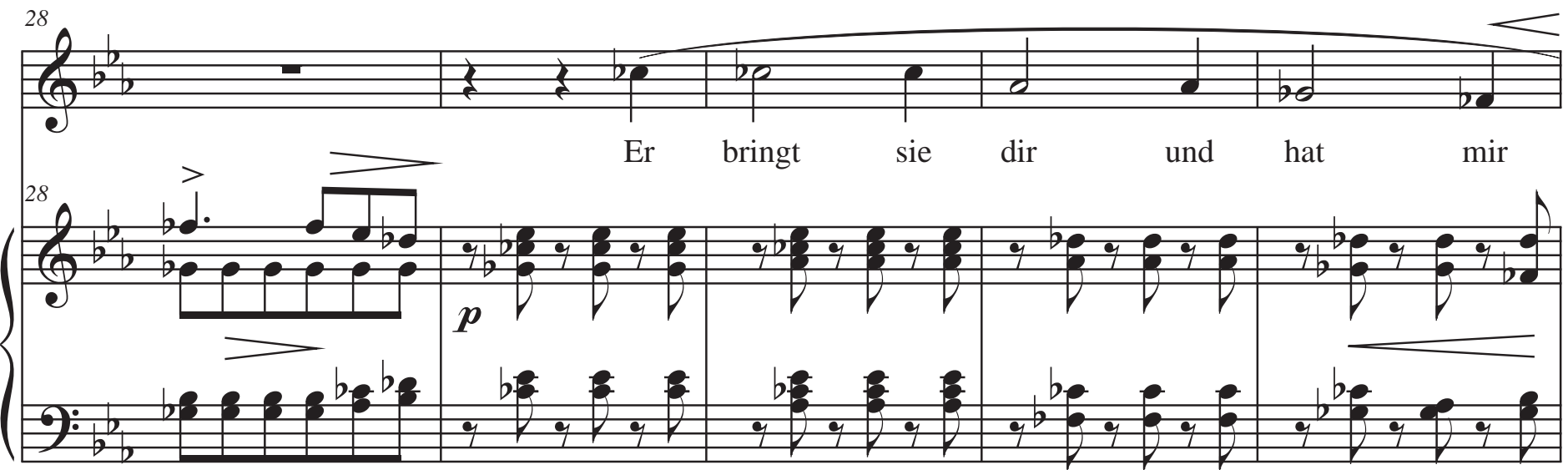
wie - der den Gruß ge - bracht

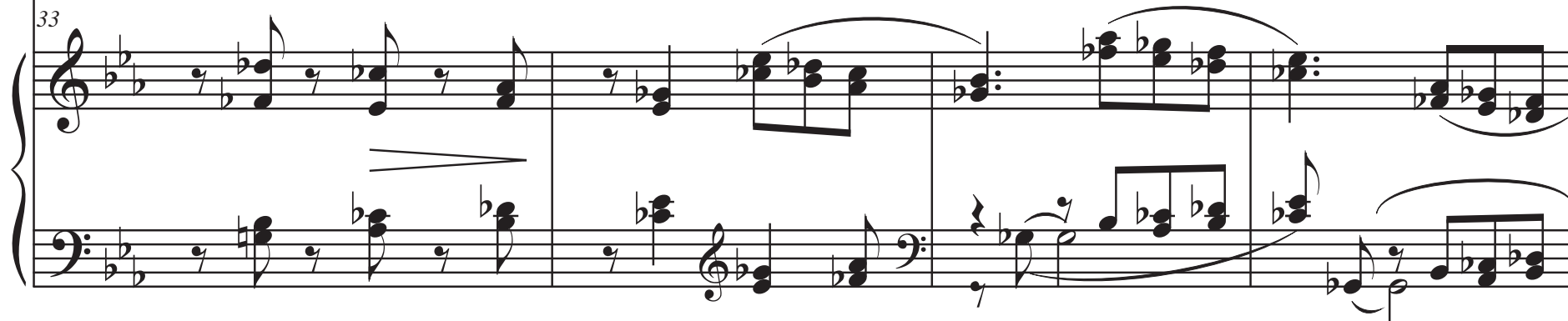

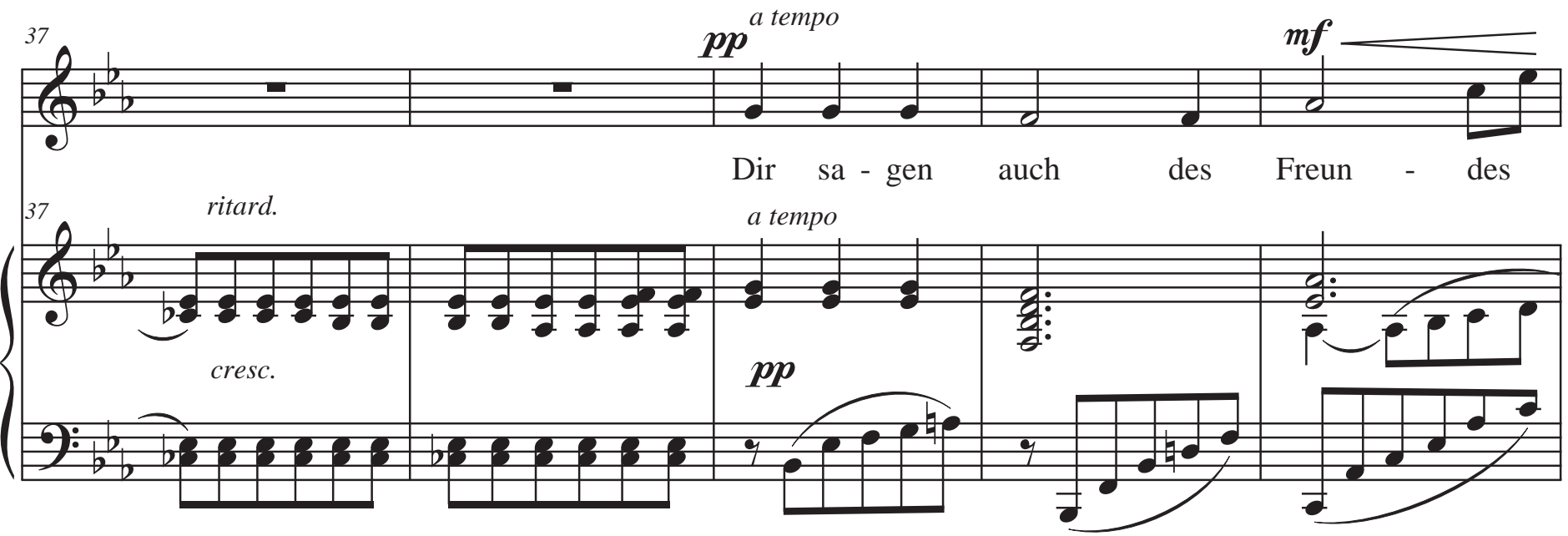



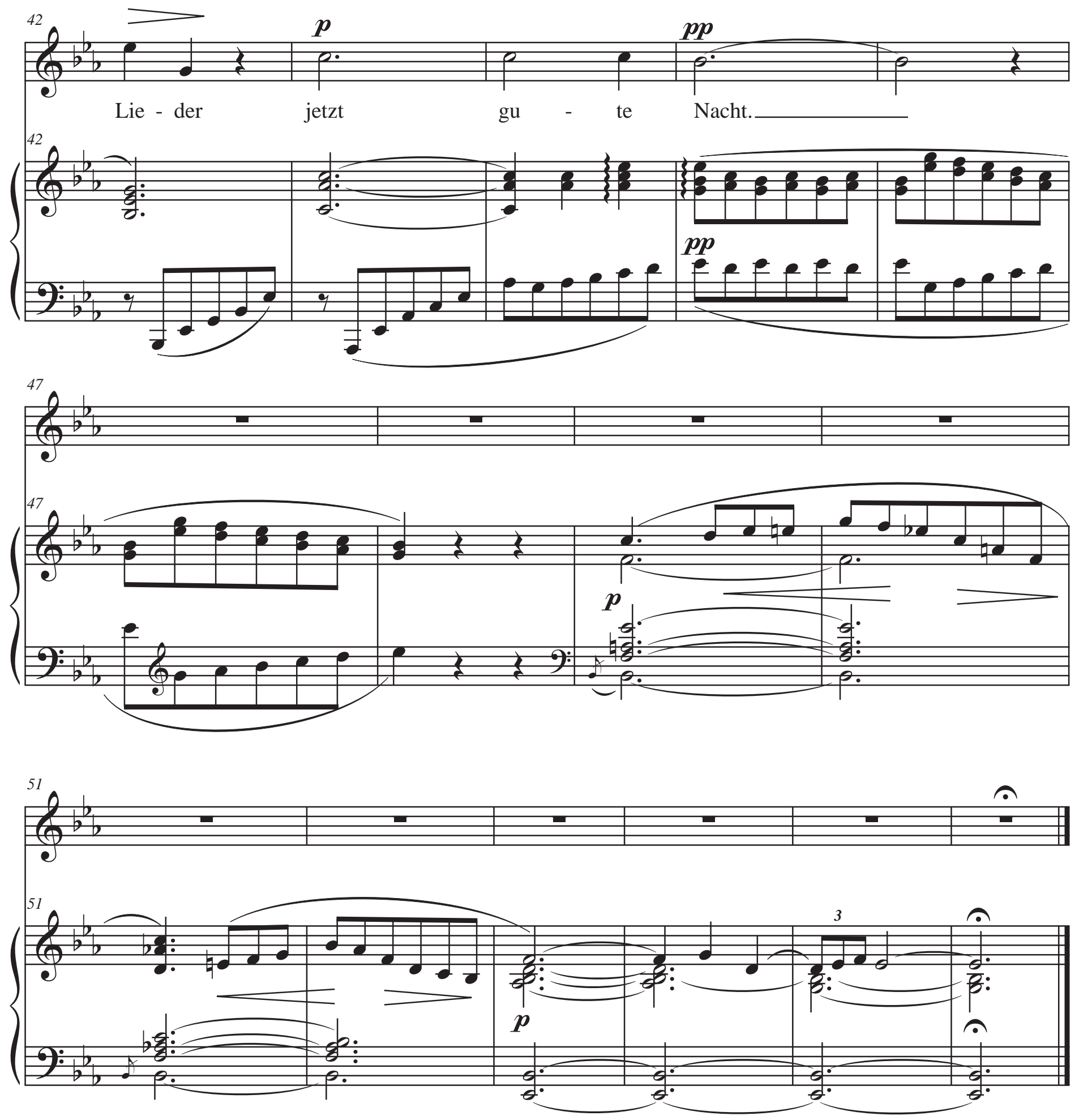


\section{Volkslied}

(Heinrich Heine)

Erstdruck

Adagio

Schwermütig

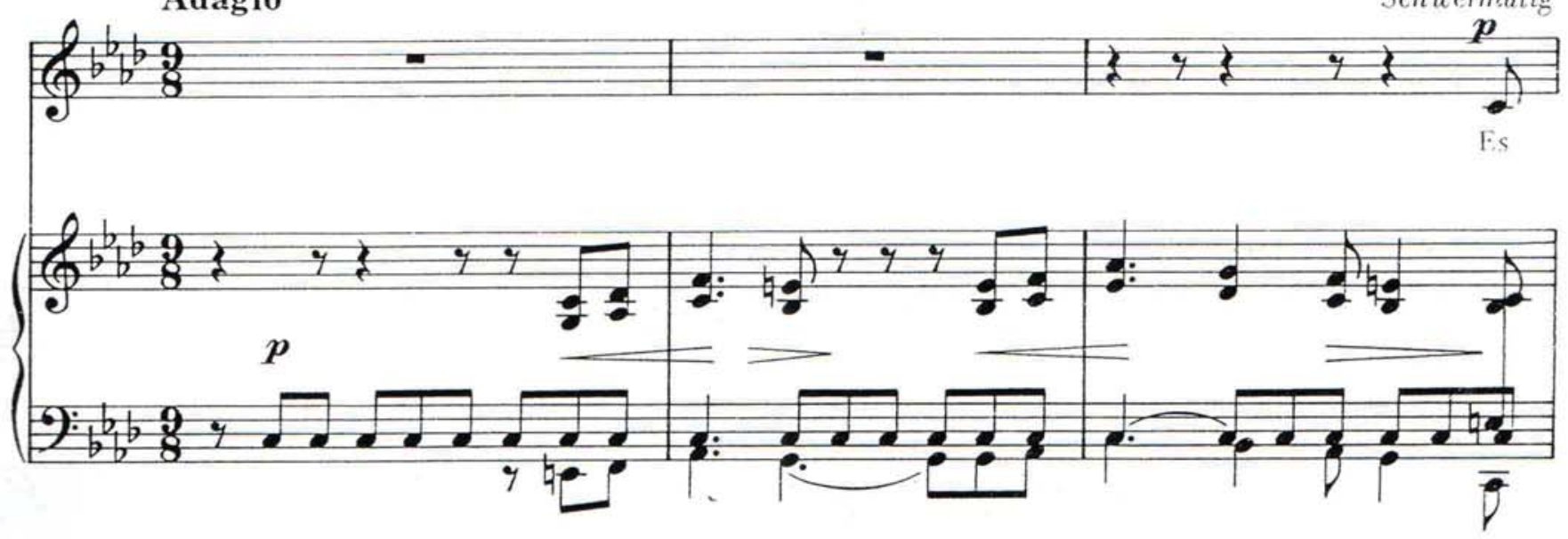

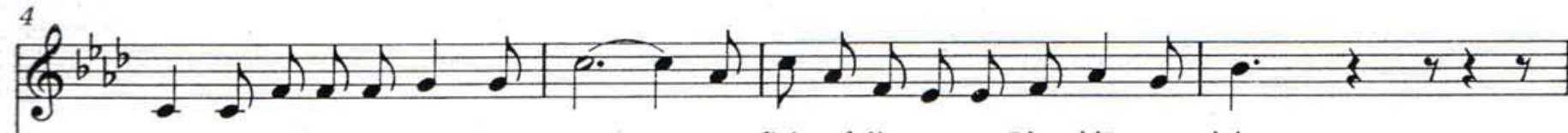
fiel ein Reif in der Früh-lings - nacht,_ er fiel auf die zar-ten Blau-blü-me - lein:
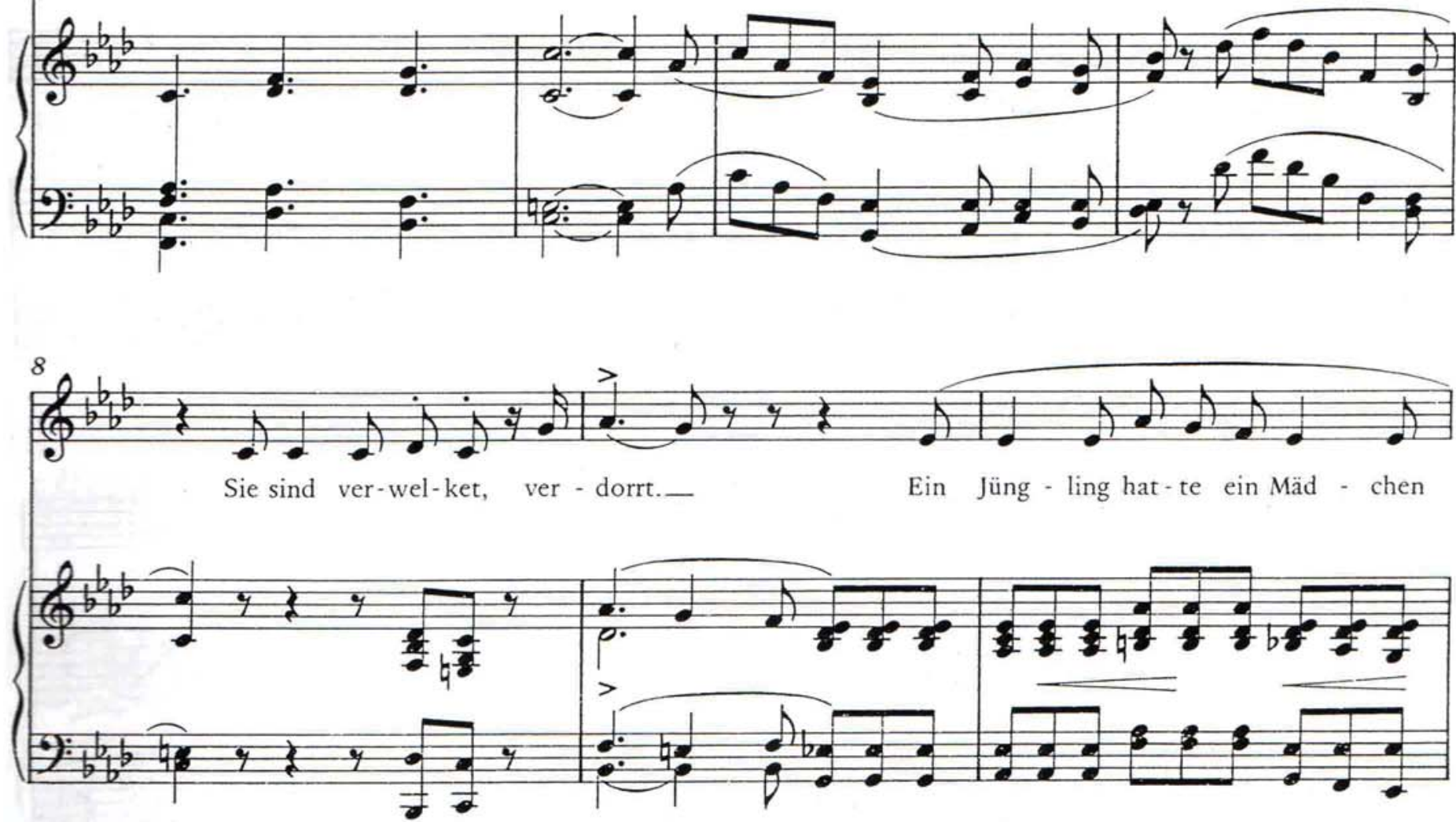


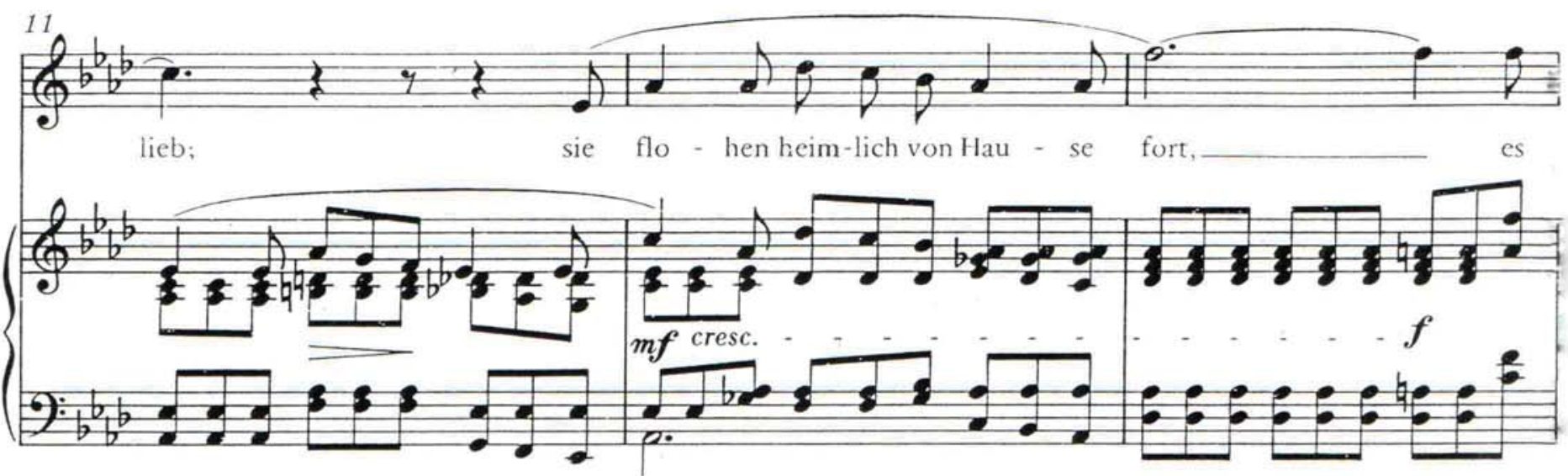

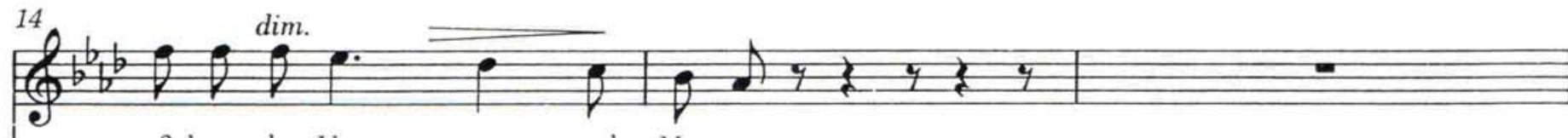
wußt'we-der Va - - ter noch Mut-ter.
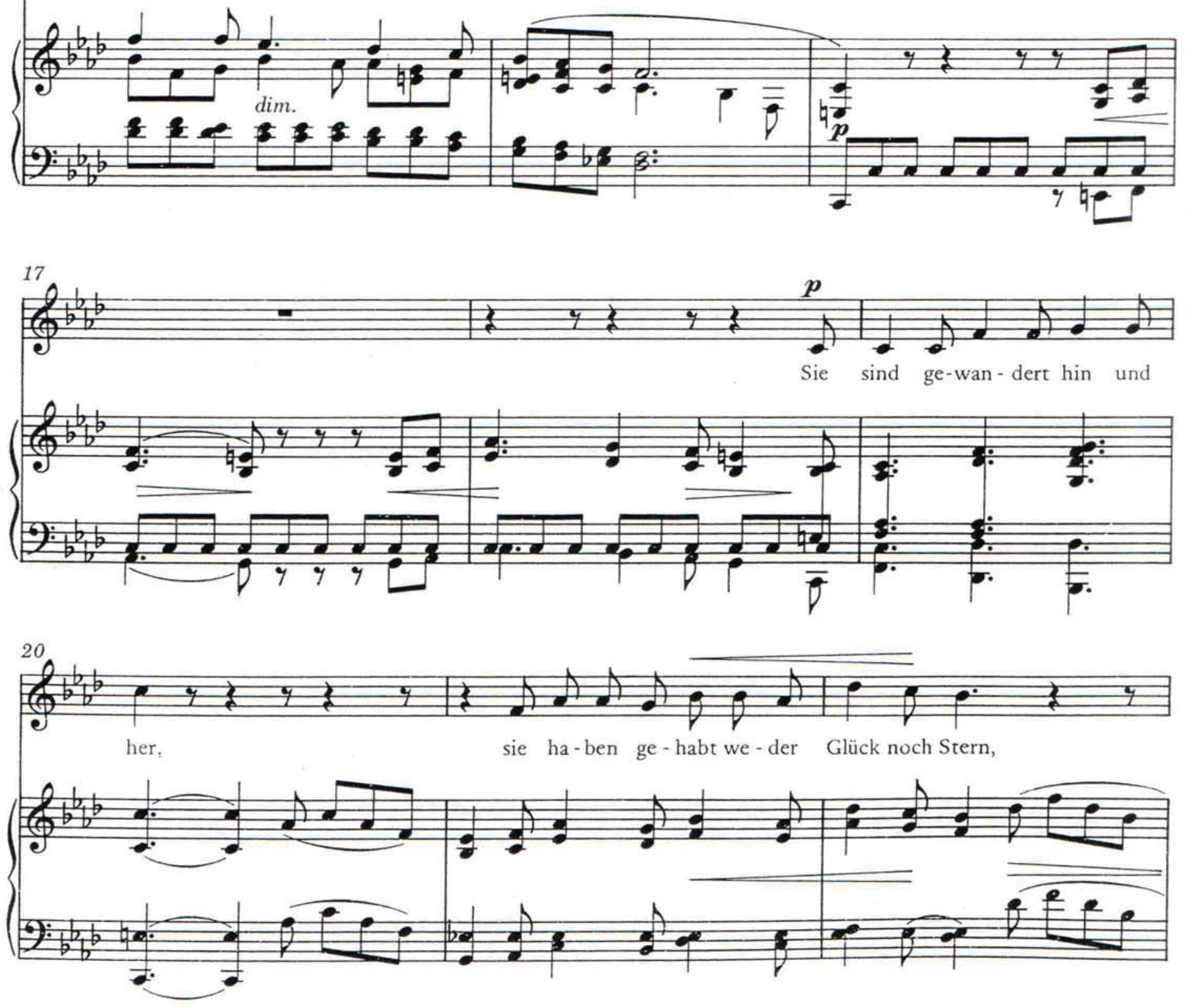

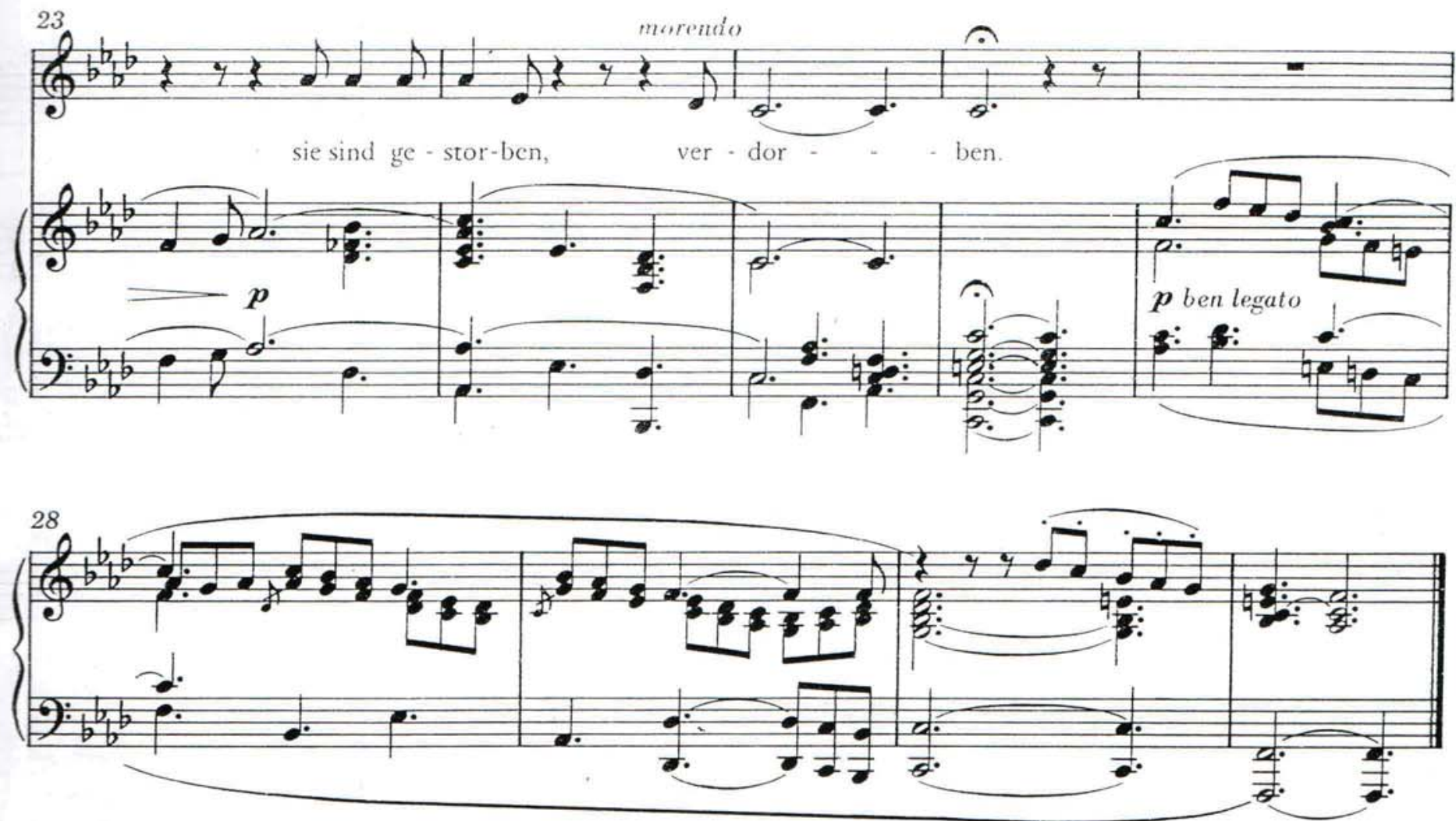

\section{Lorelei}

(Heinrich Heine)

Schnell

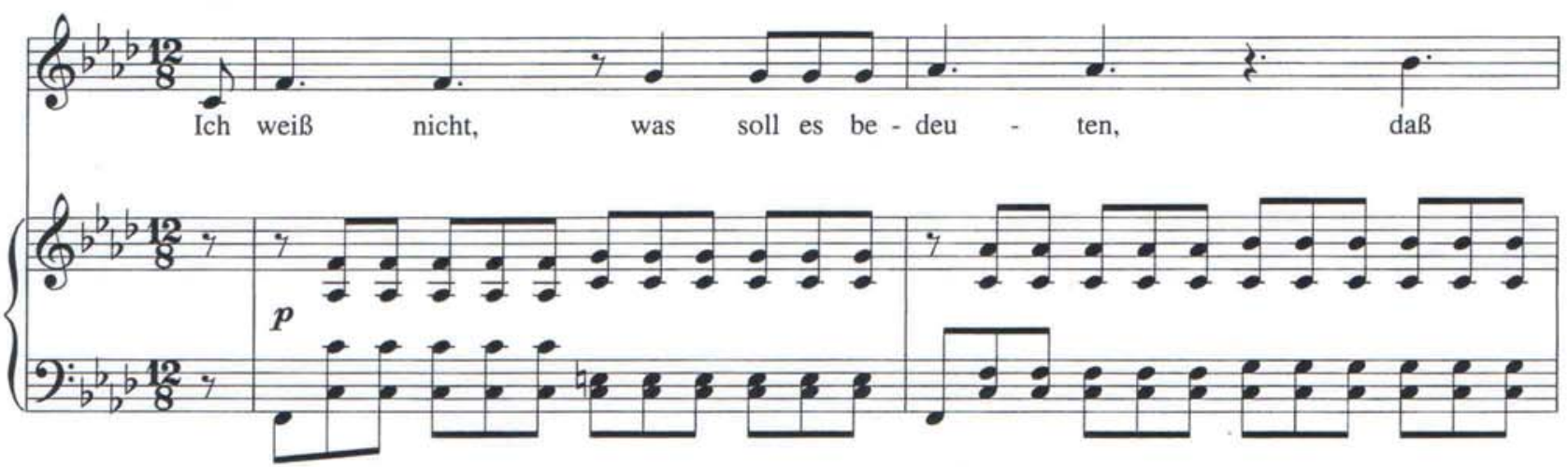



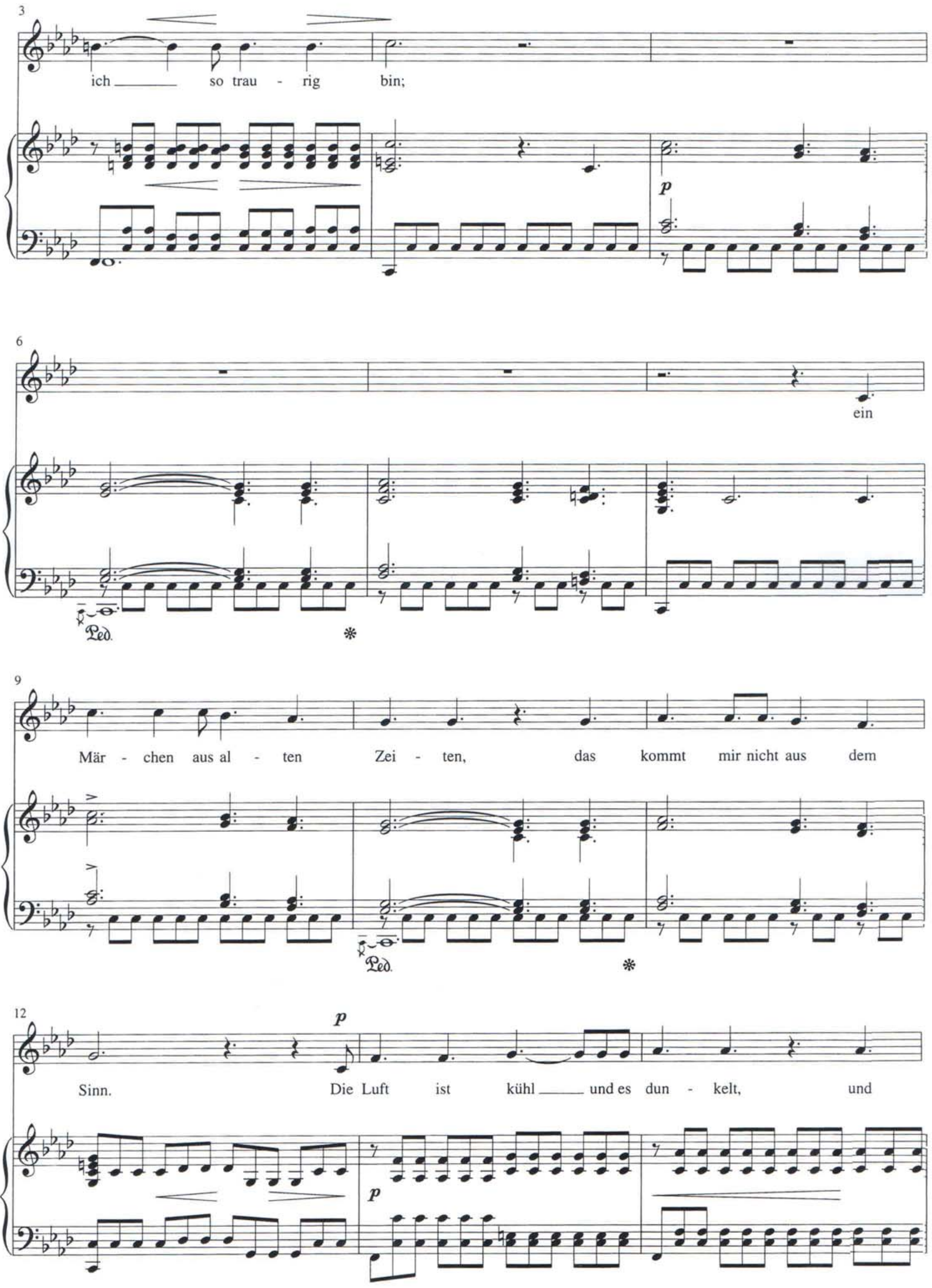


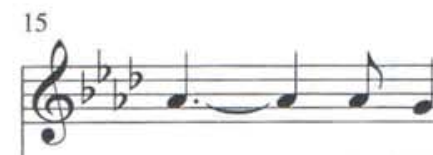

hig fließt der

hig flieBt der

$p$

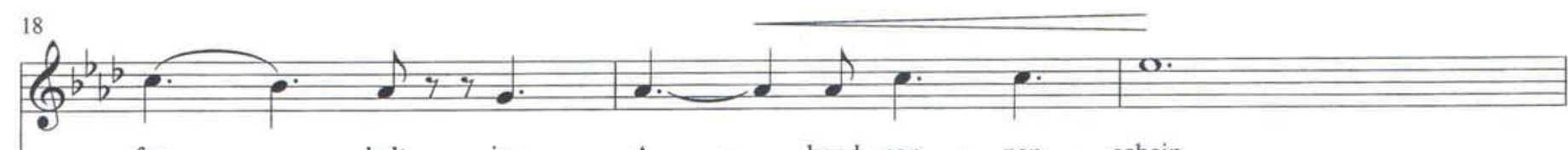

fun - kelt im A - bend - son - nen - schein.

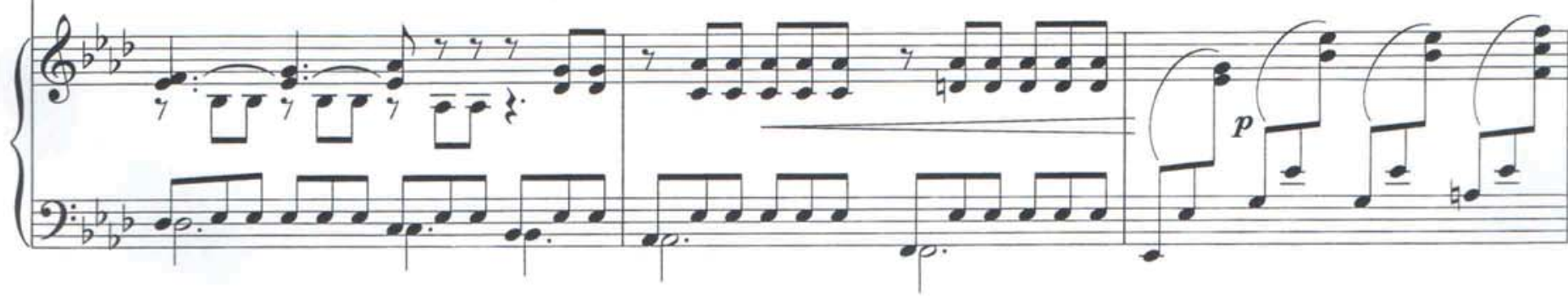

(9) -
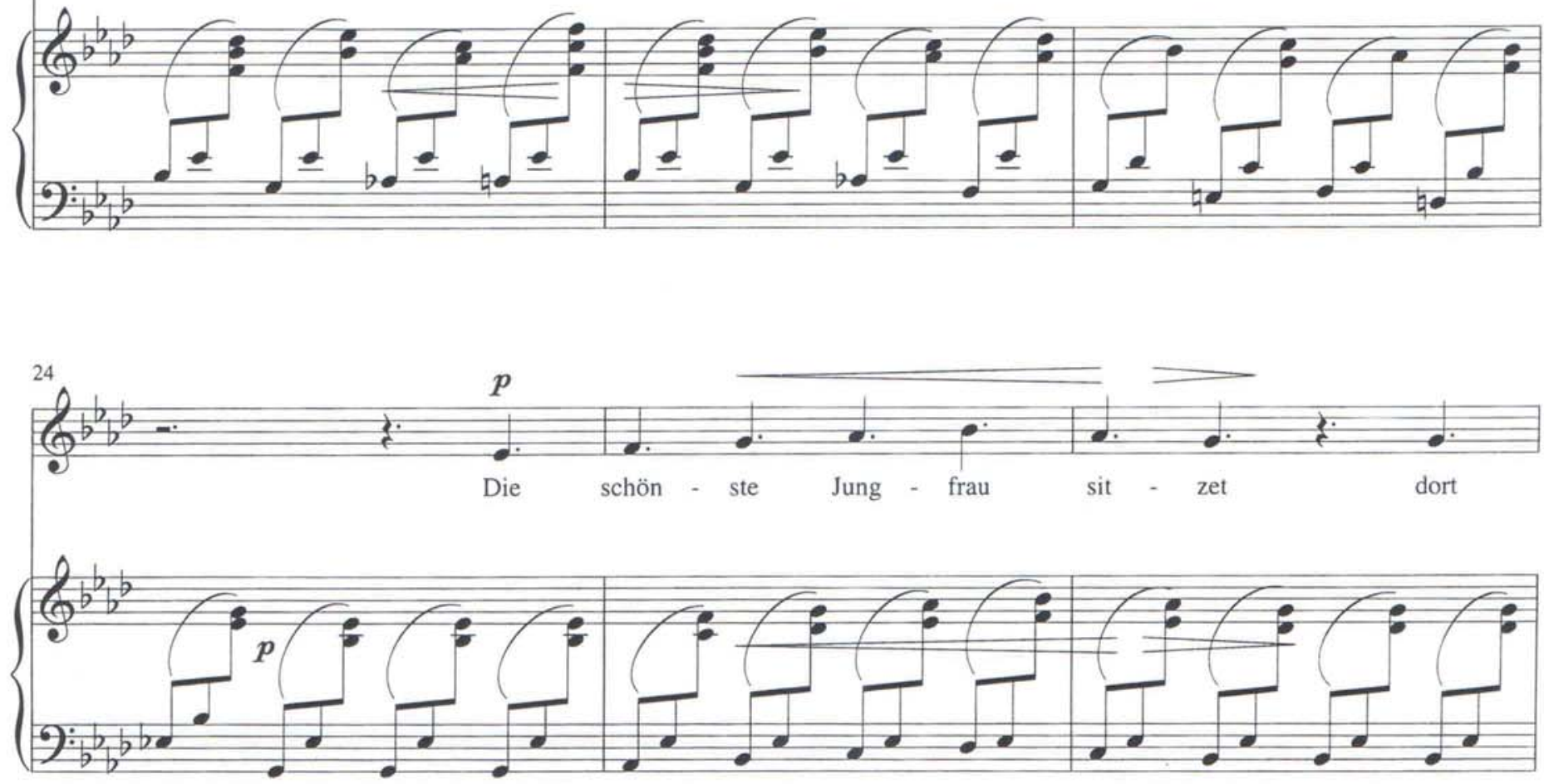
27

$\int_{0}^{b}+\infty$

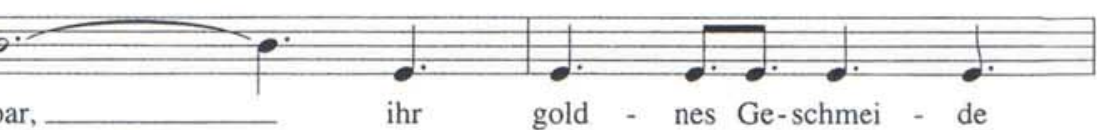


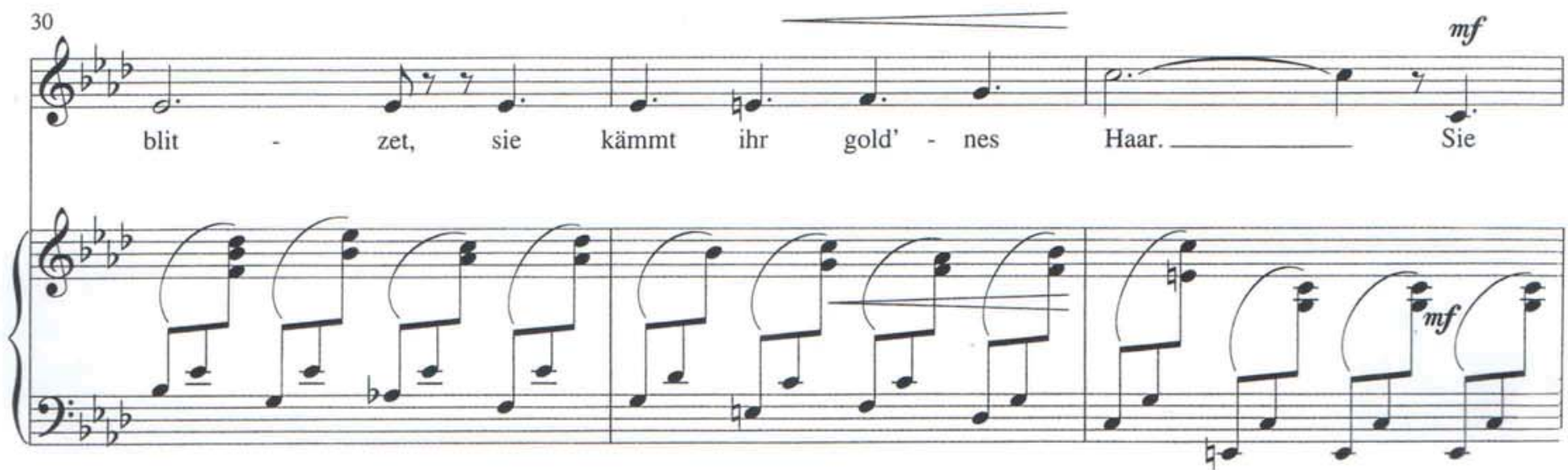

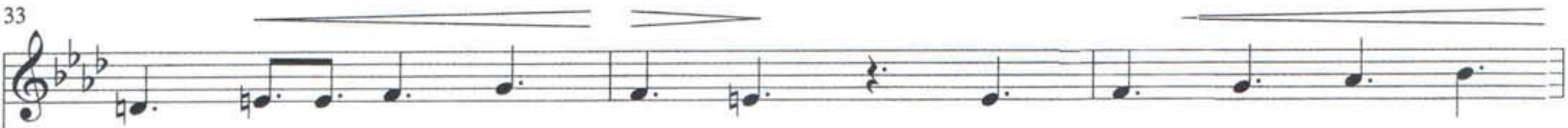
kämmt es mit gold' - nem Kam - me und singt ein Lied da -
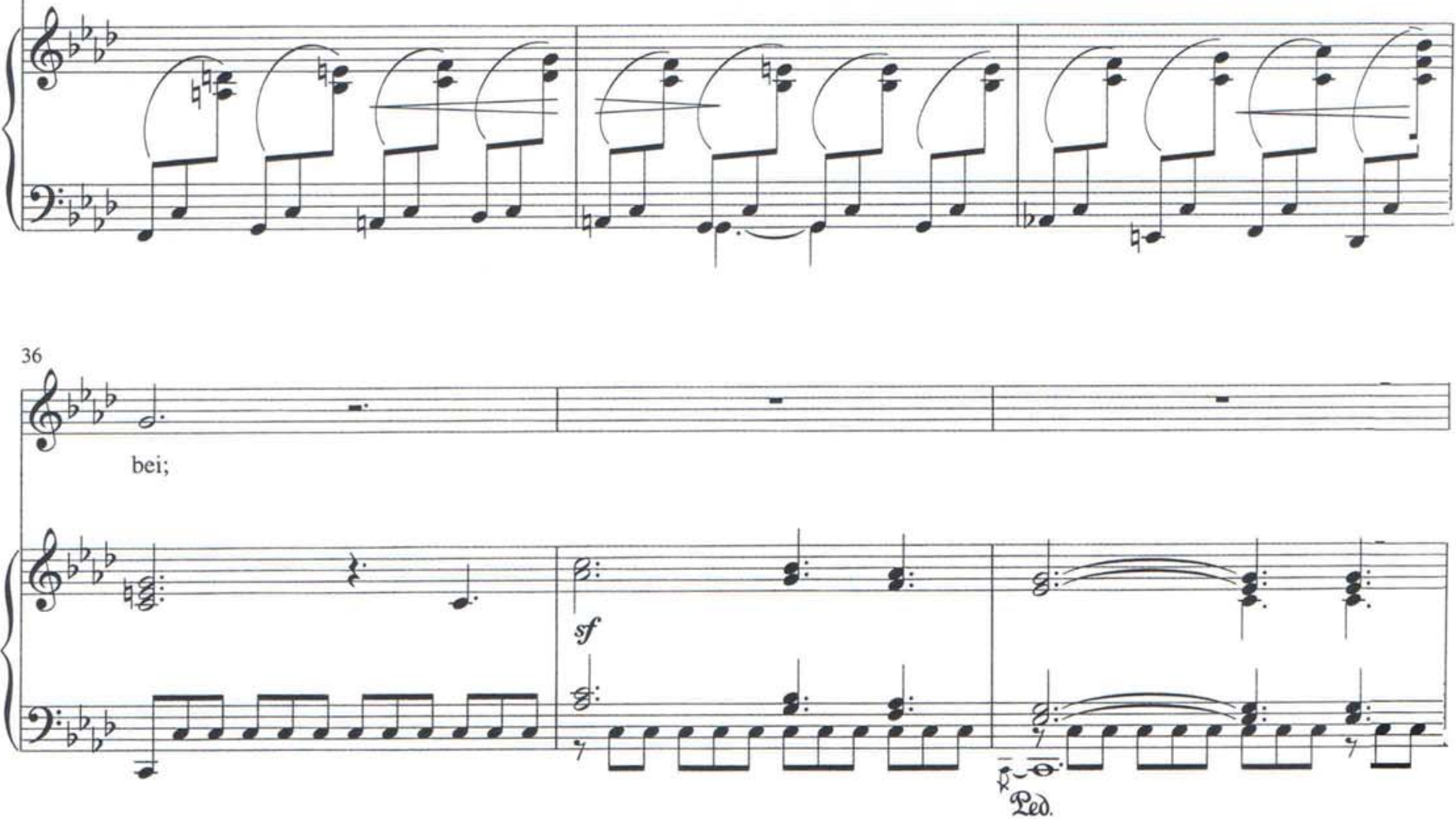
39

$\frac{b}{b a b}$

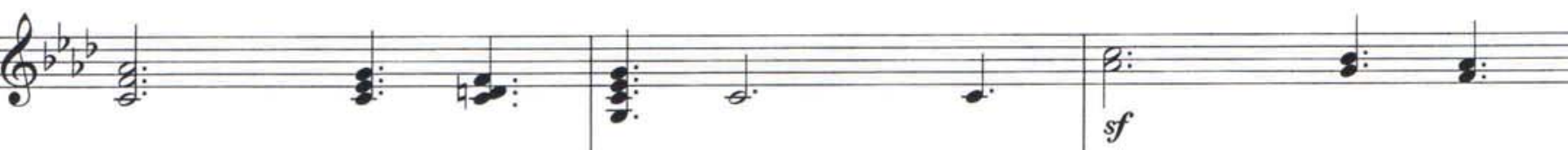

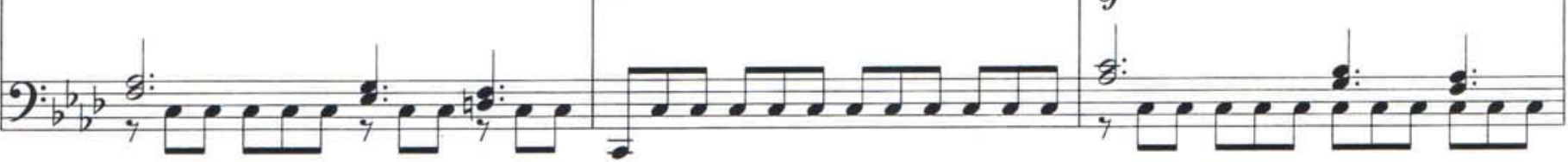

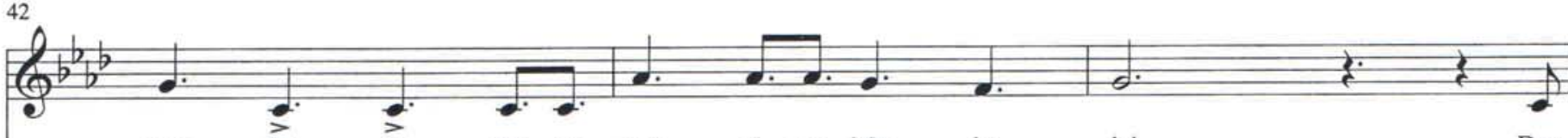
wun - $\overrightarrow{\text { der }}-\overrightarrow{\mathrm{sa}}-\mathrm{me}$ ge - wal - ti - ge Me - lo - dei. Den

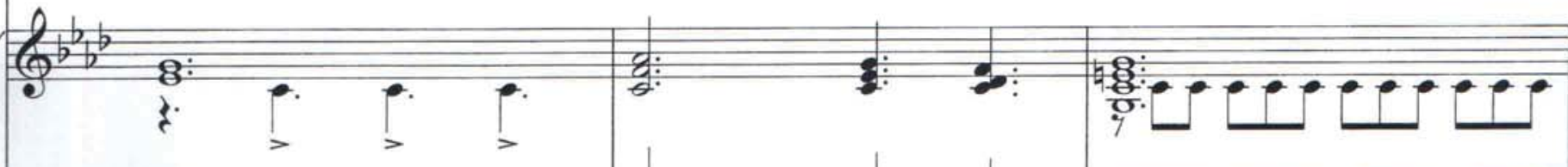

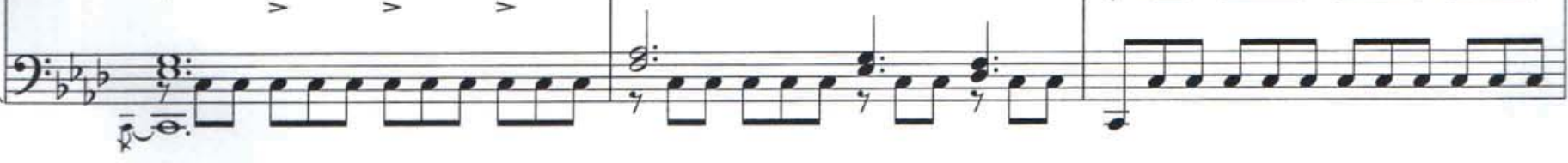

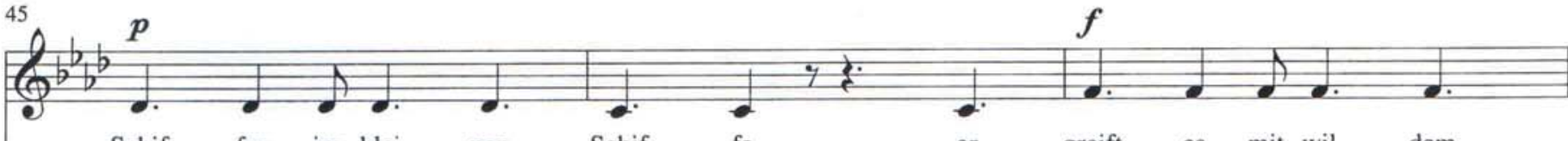
Schif - fer im klei - nen Schif - fe er - greift es mit wil - dem

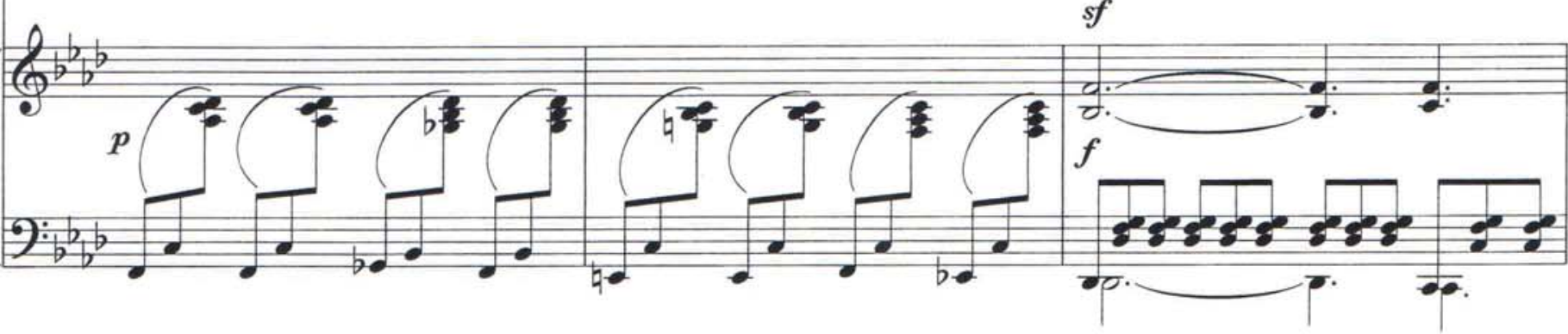

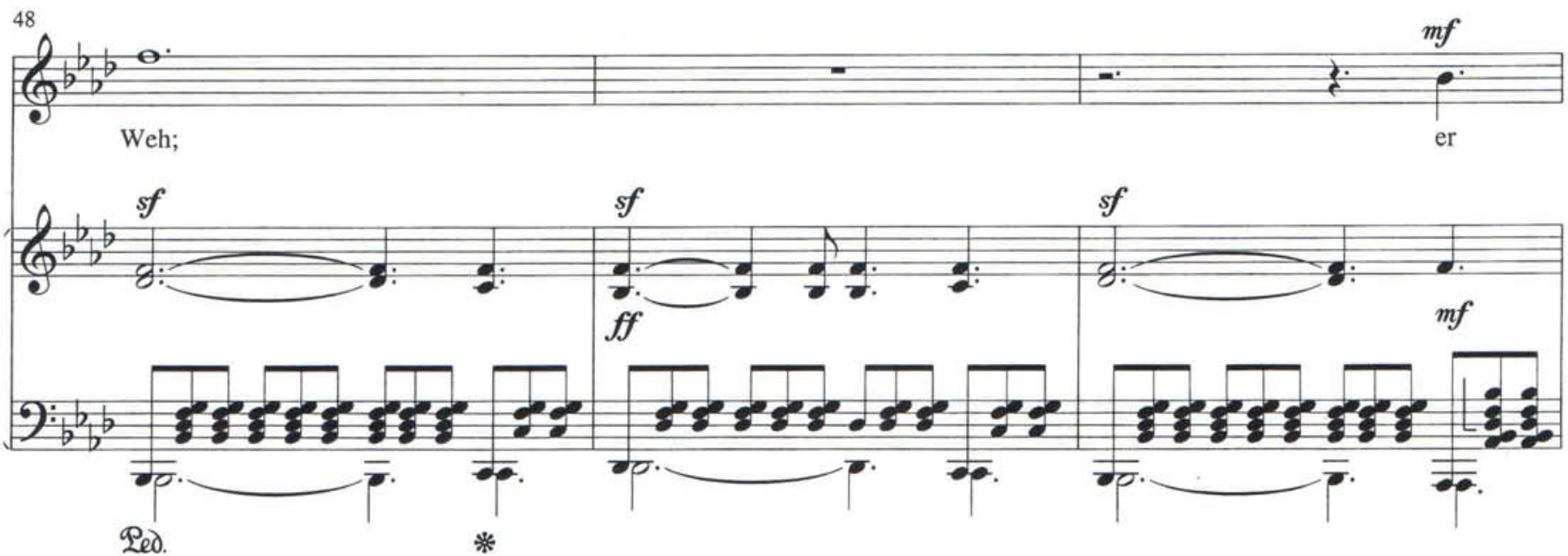



schaut nicht die Fel - sen - rif - fe,

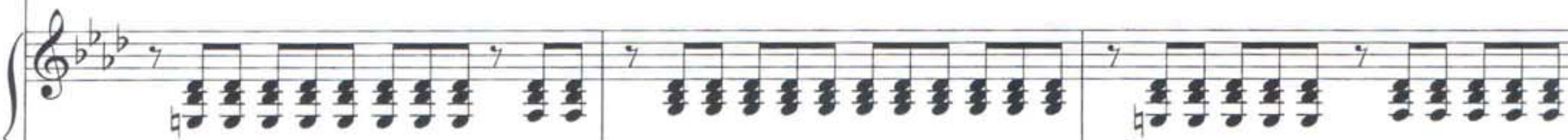

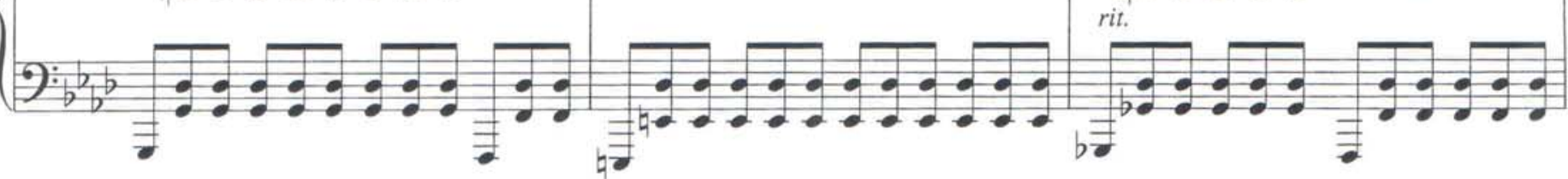

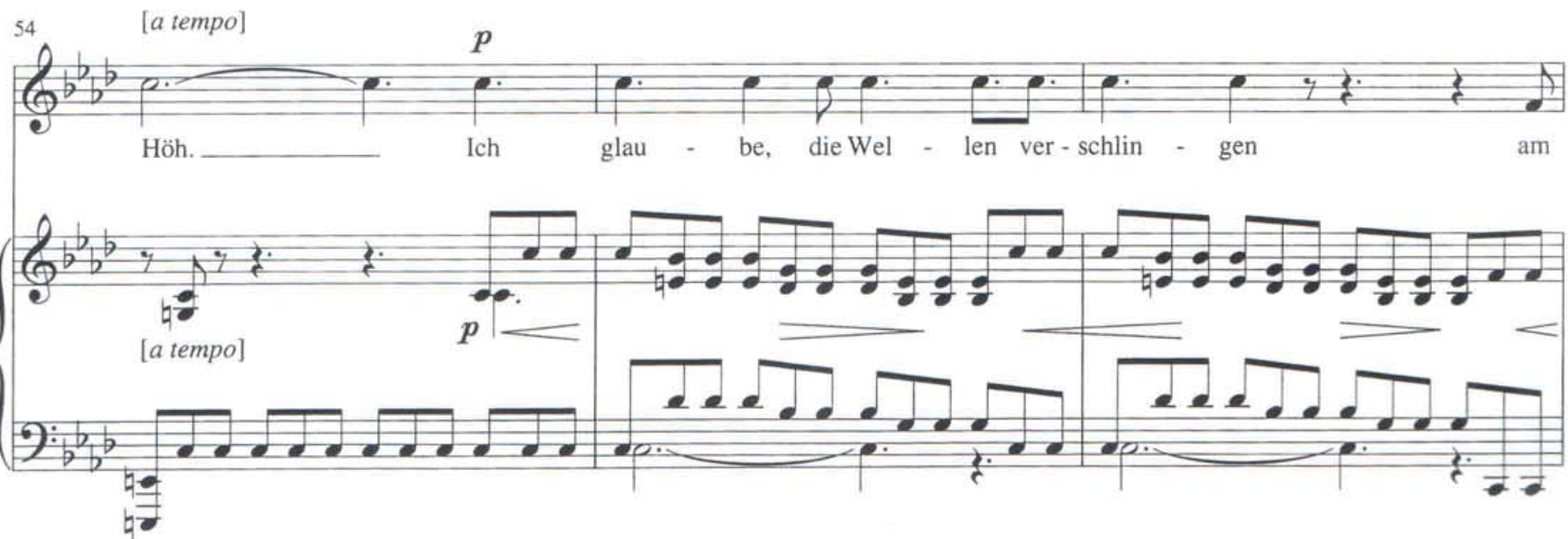

$g^{b} b^{b}+\cdots$

poco a poco cresc.

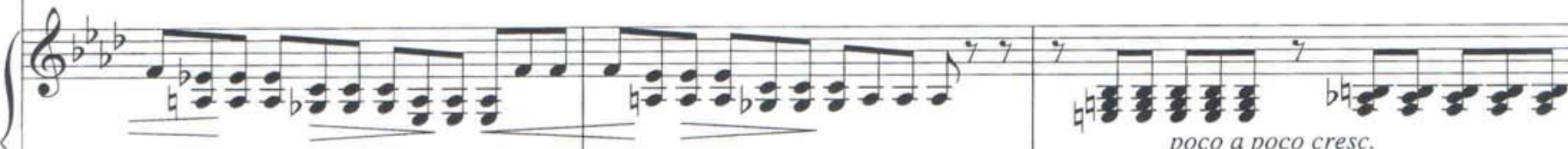
$\frac{\left(y_{i} b_{b}^{b}\right.}{\bar{a}}$

$\underbrace{Q}_{\text {Sin - gen }}$

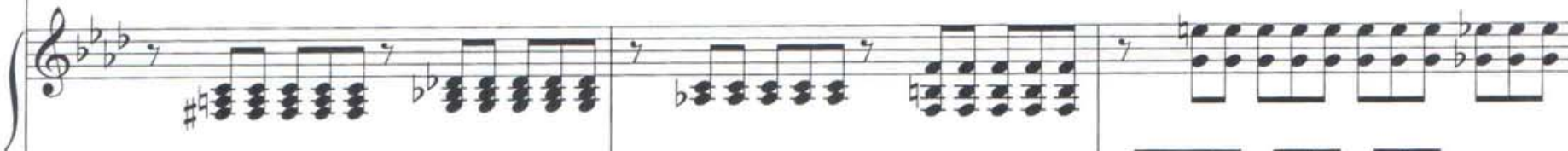

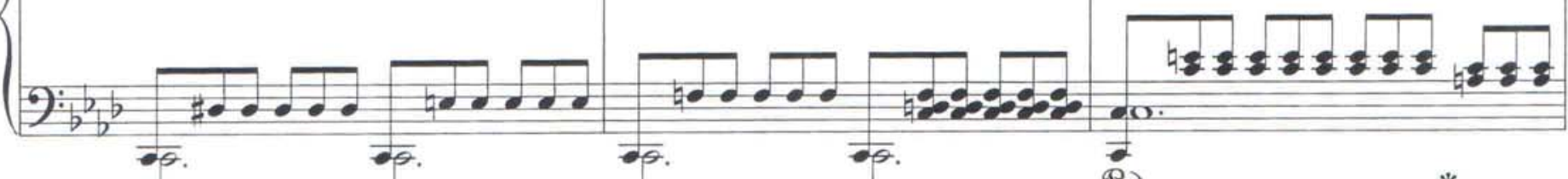
ped

Ped.

Ted

Sed

$*$ 


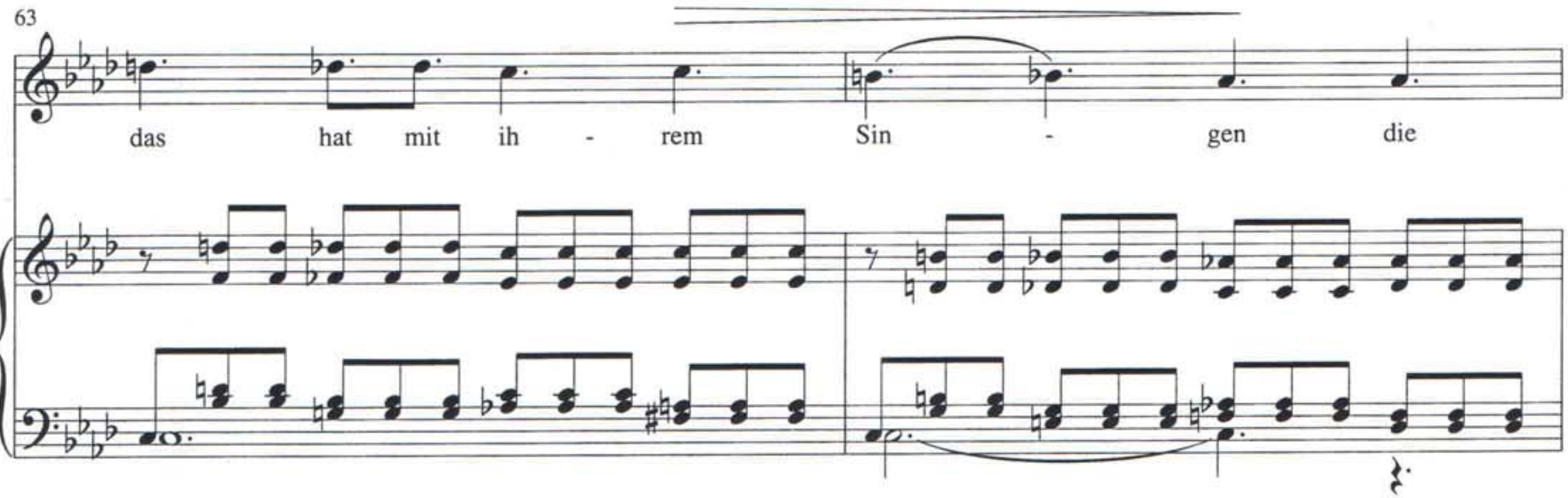

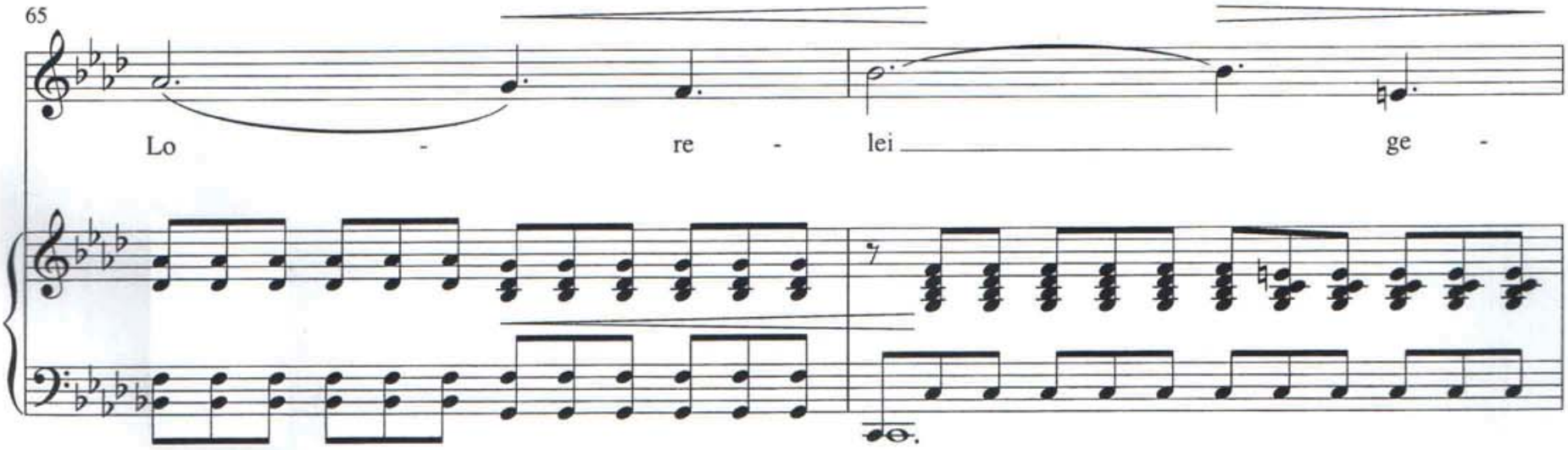

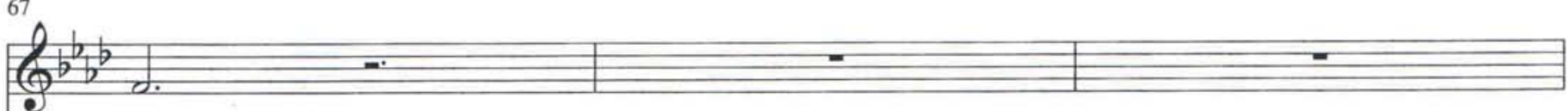
$\tan$.

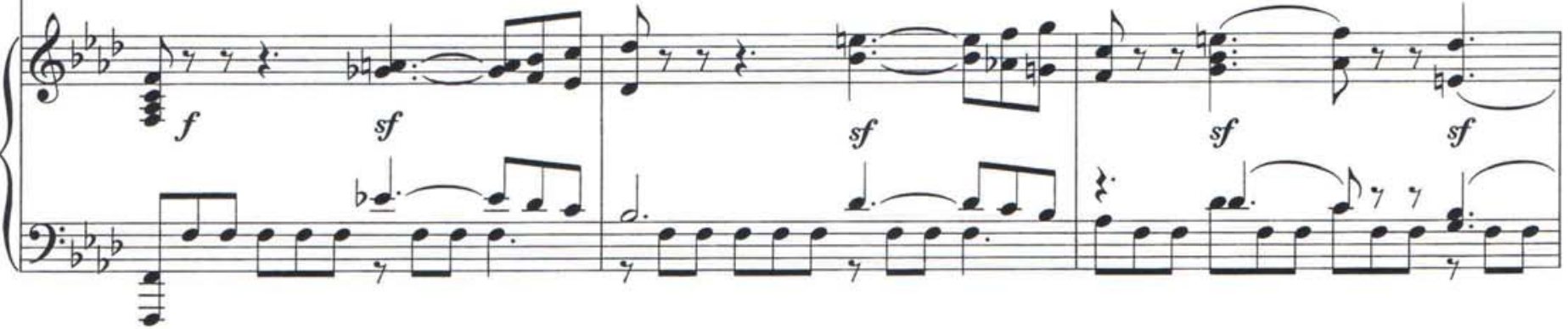

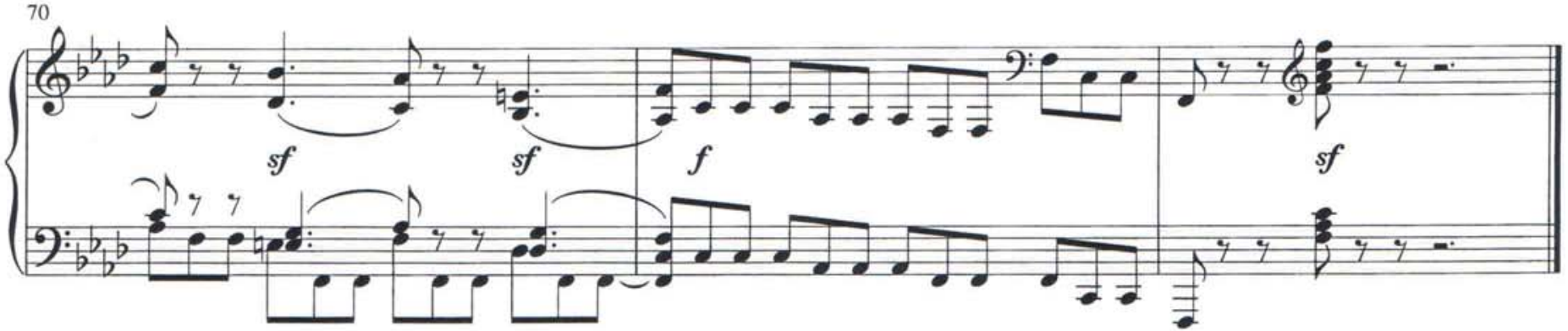




\section{Oh weh des Scheidens, das er tat}

(Friedrich Rückert)

Sehr langsam und mit tiefster Empfindung
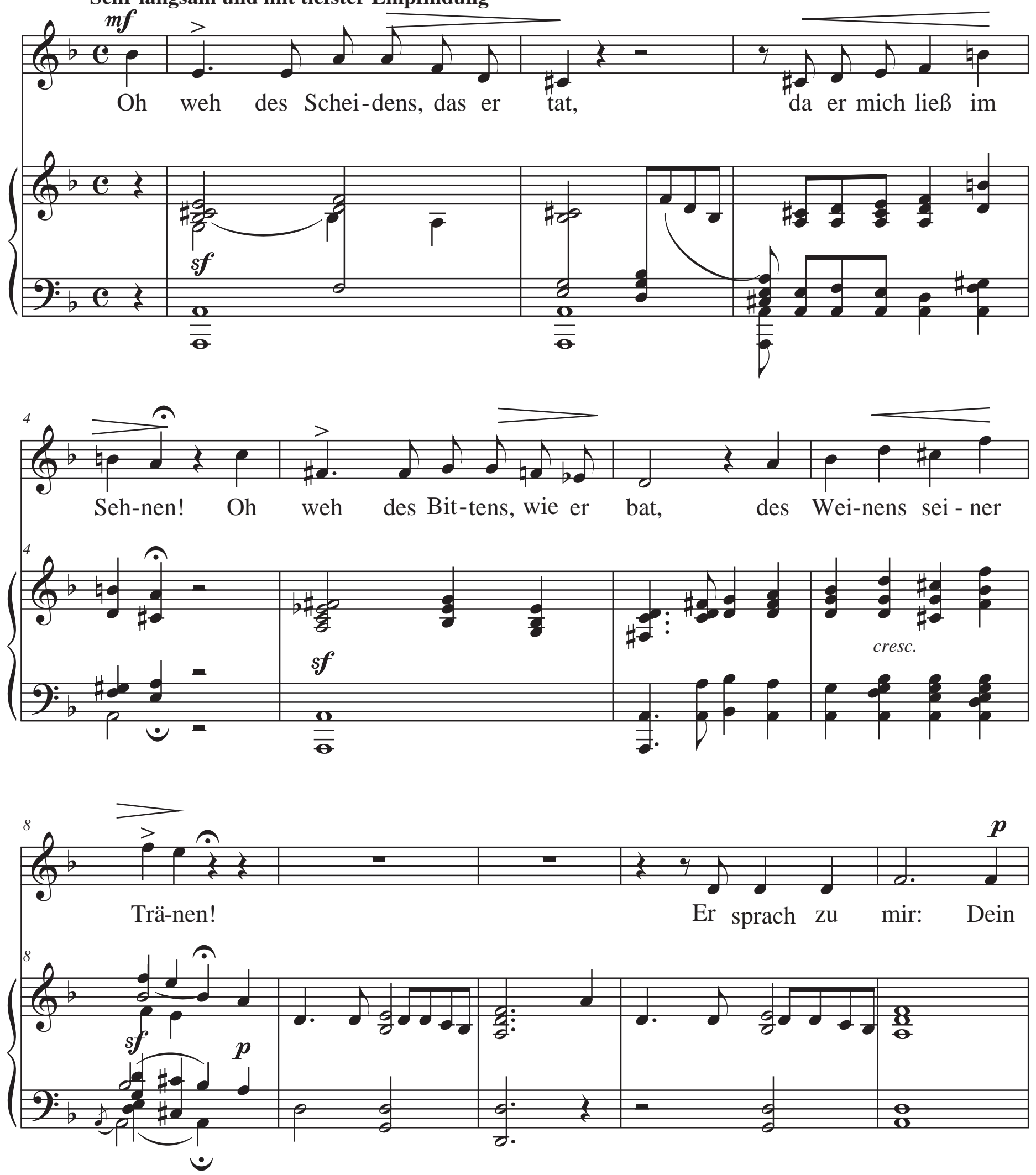


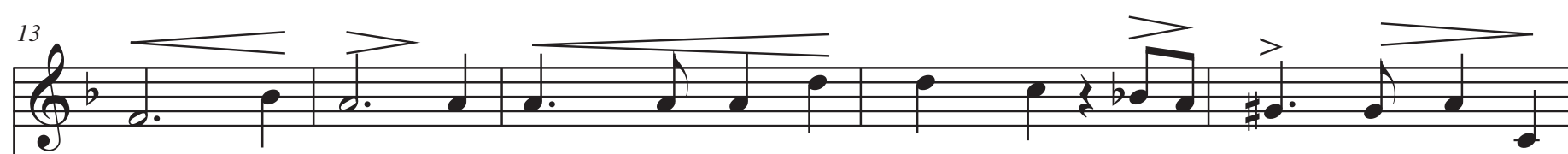

Trau - ern laß! und schied doch selbst in Schmer-zen, und schied doch selbst in
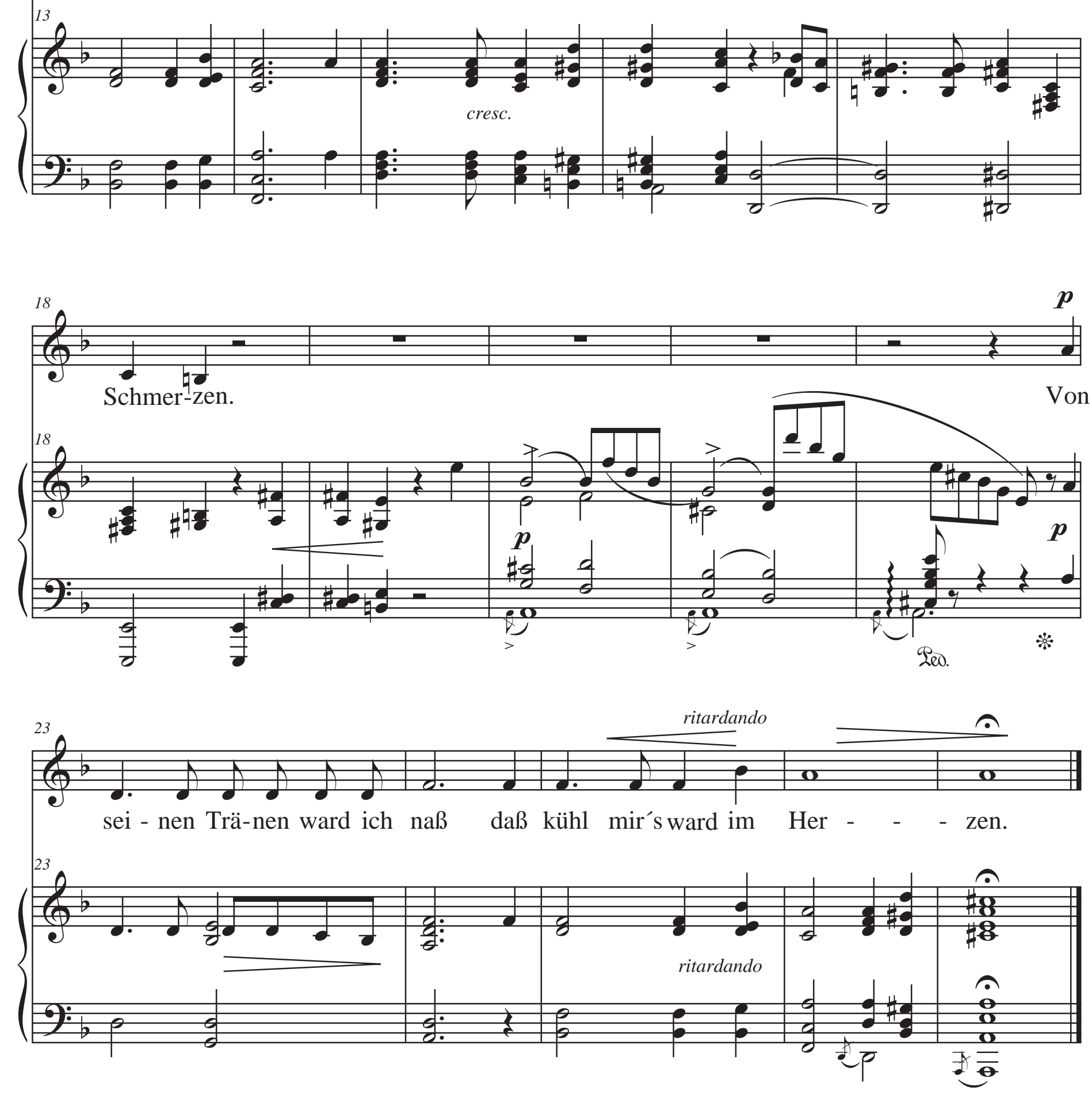


\section{Beim Abschied}

(Friederike Serre)

Erstdruck
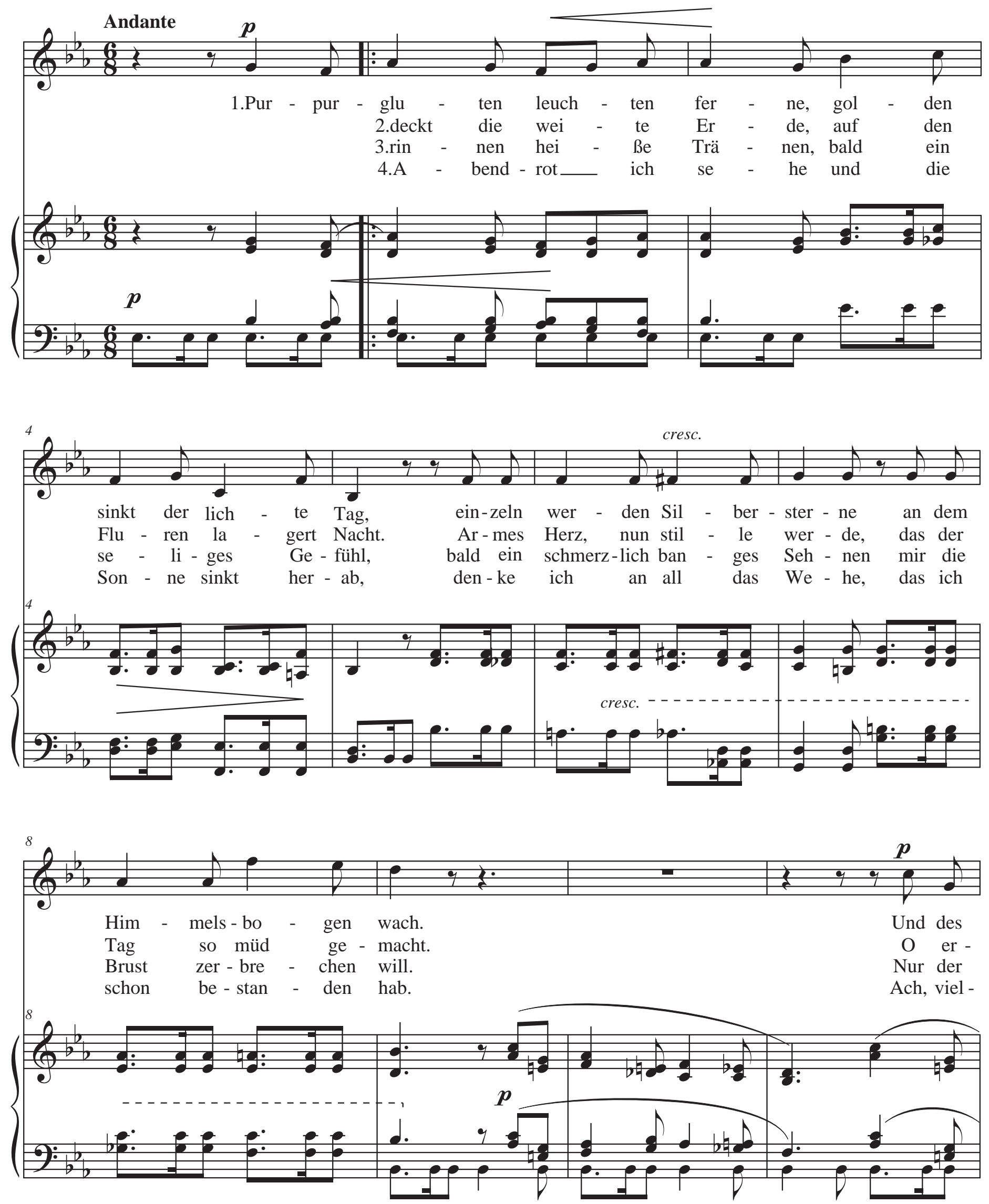

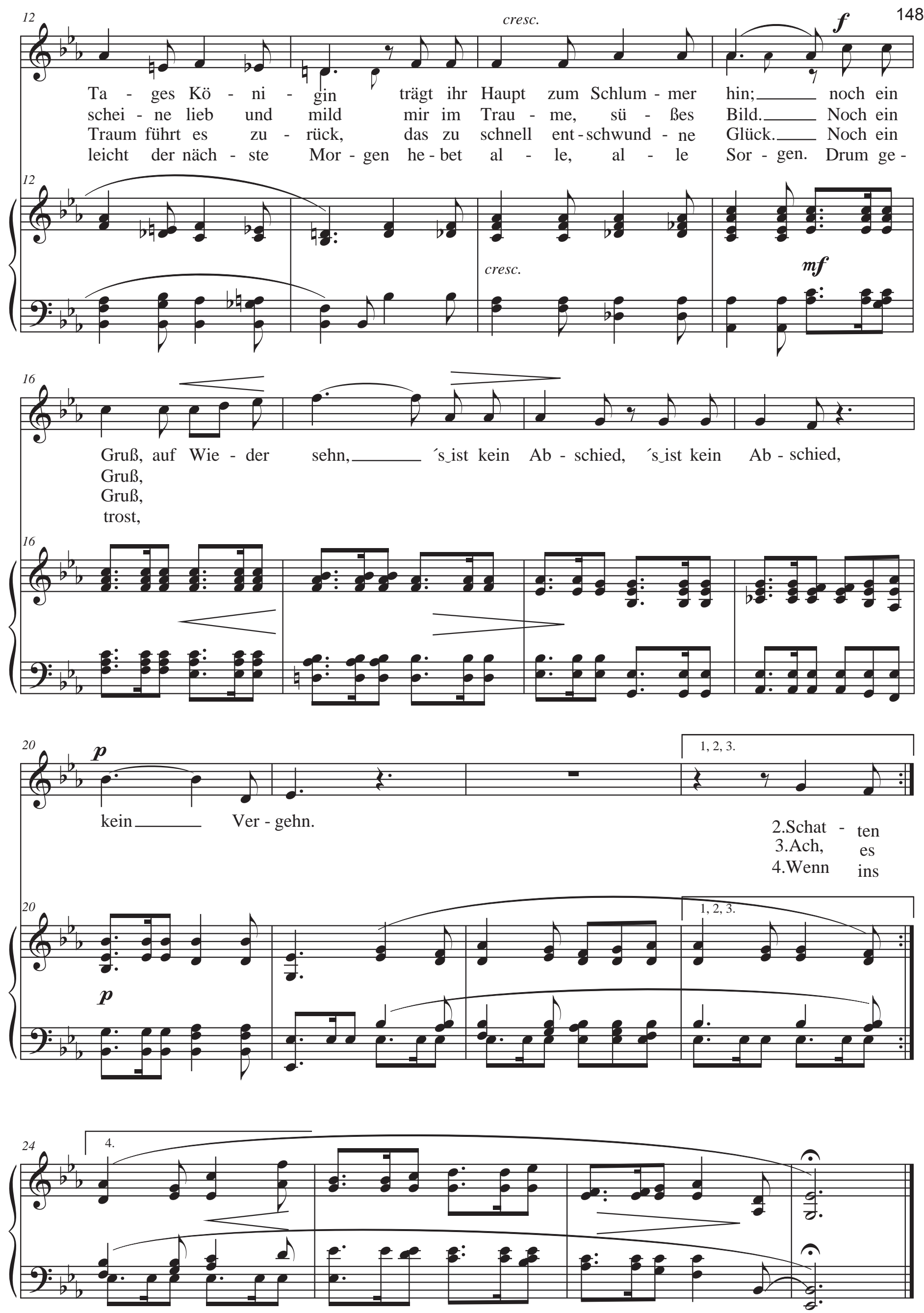


\section{Das Veilchen}

(Johann Wolfgang von Goethe)

Erstdruck
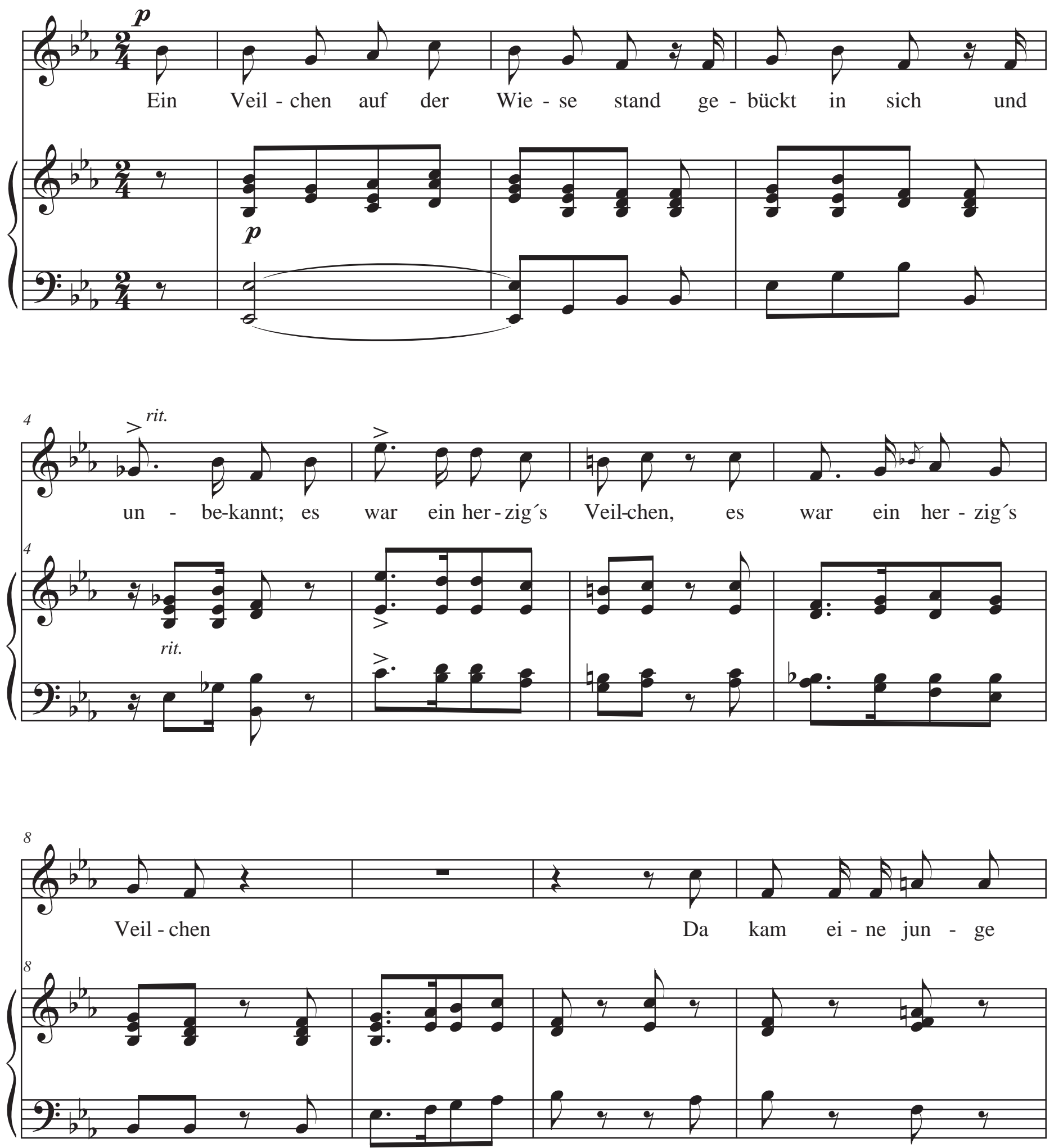

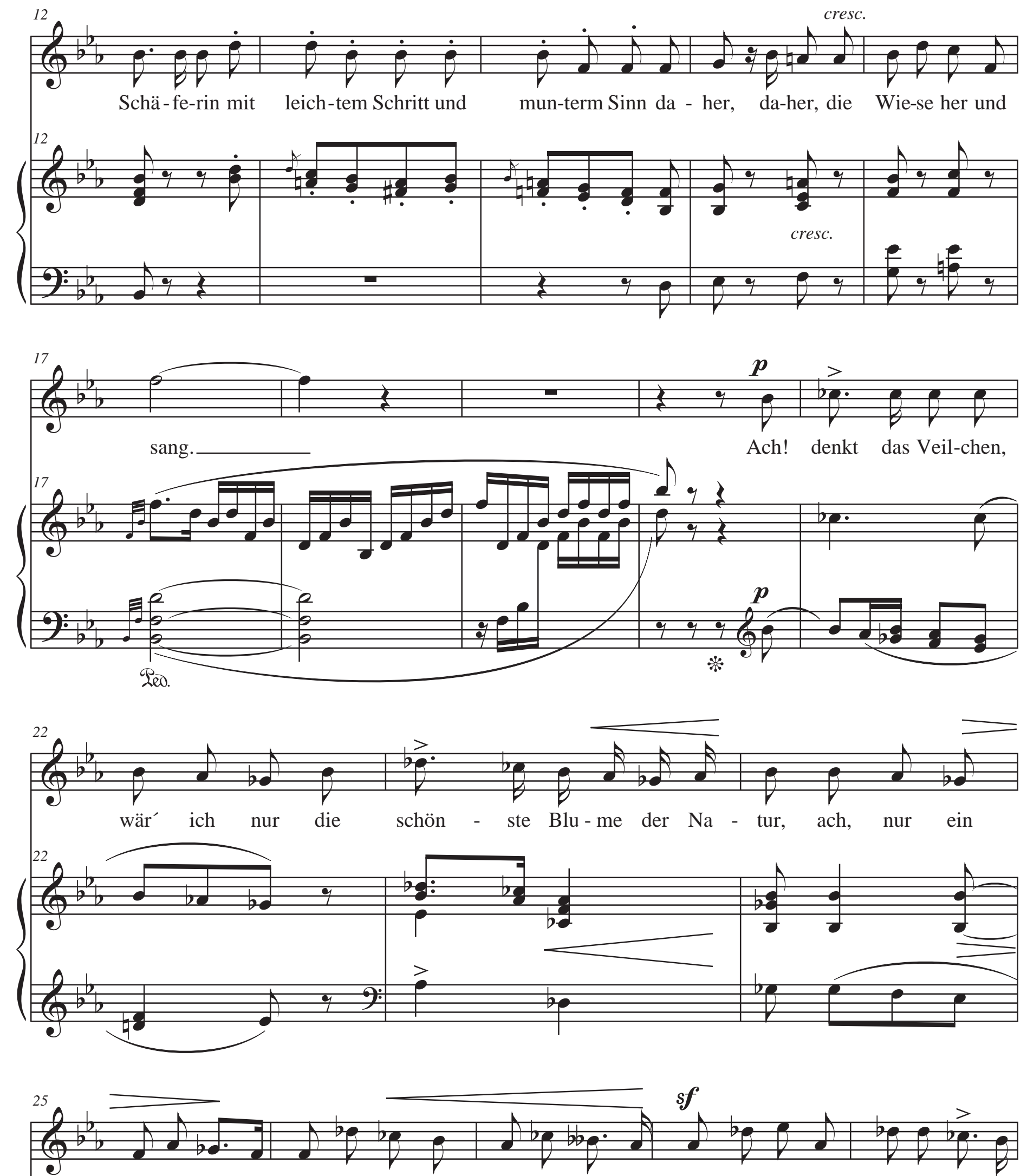
klei-nes Weil - chen, bis mich das Lieb-chen ab - ge-pflückt und an dem Bu-sen matt ge-

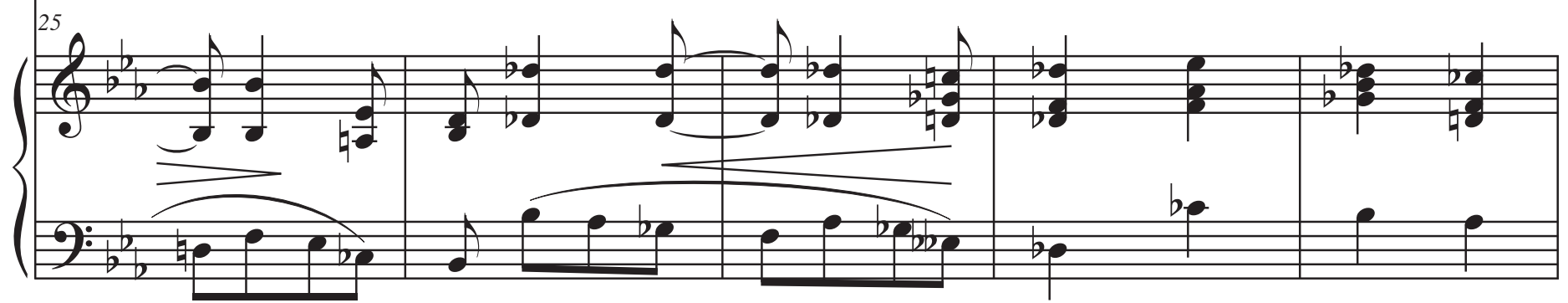




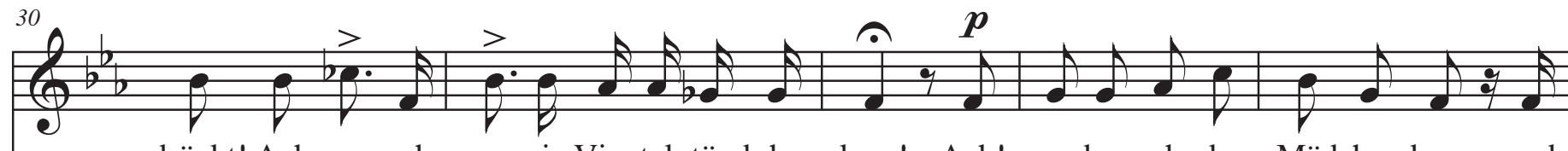
drückt! Ach nur, ach nur ein Vier-tel-stünd-chen lang! Ach! a-ber ach, das Mädchen kam und
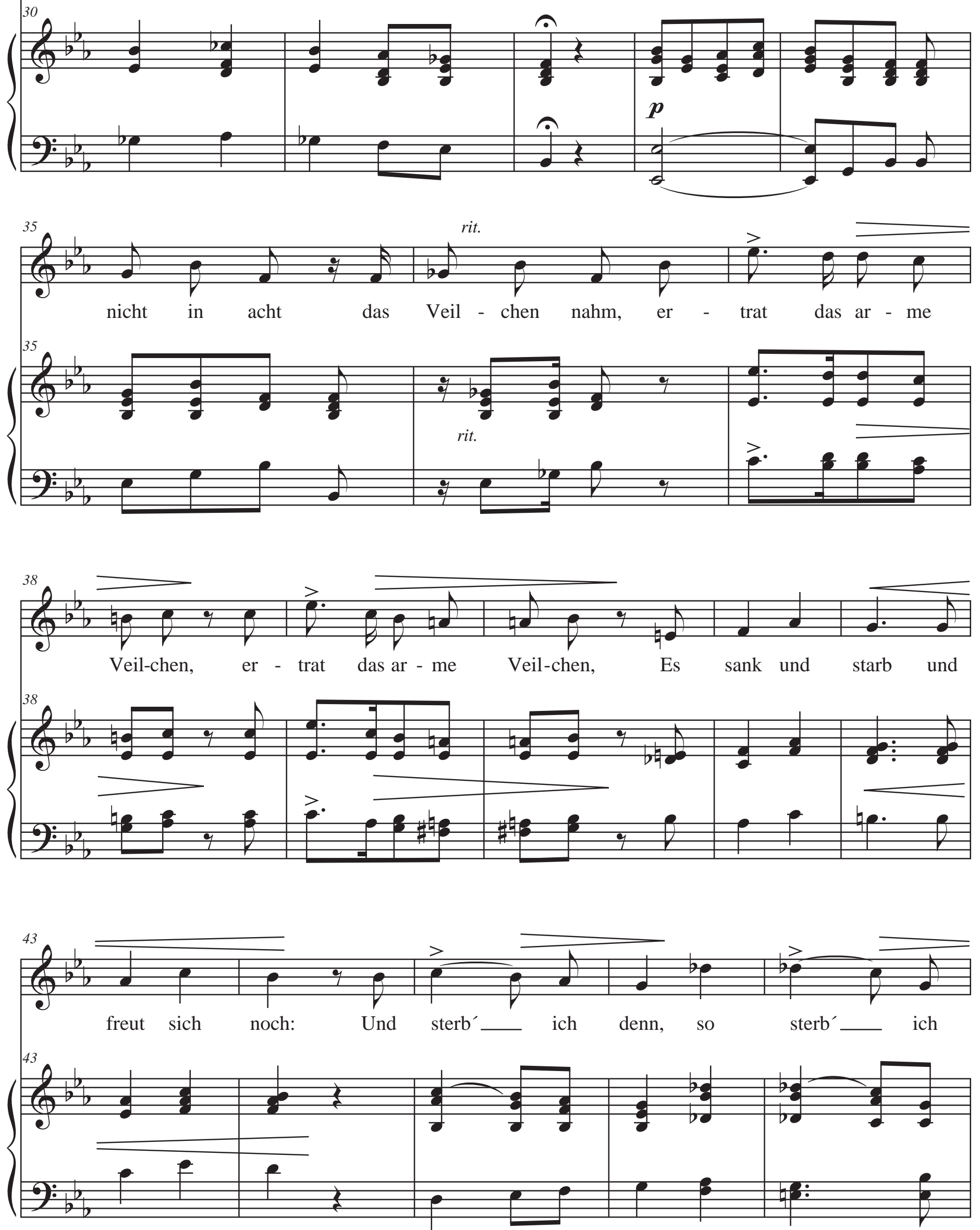

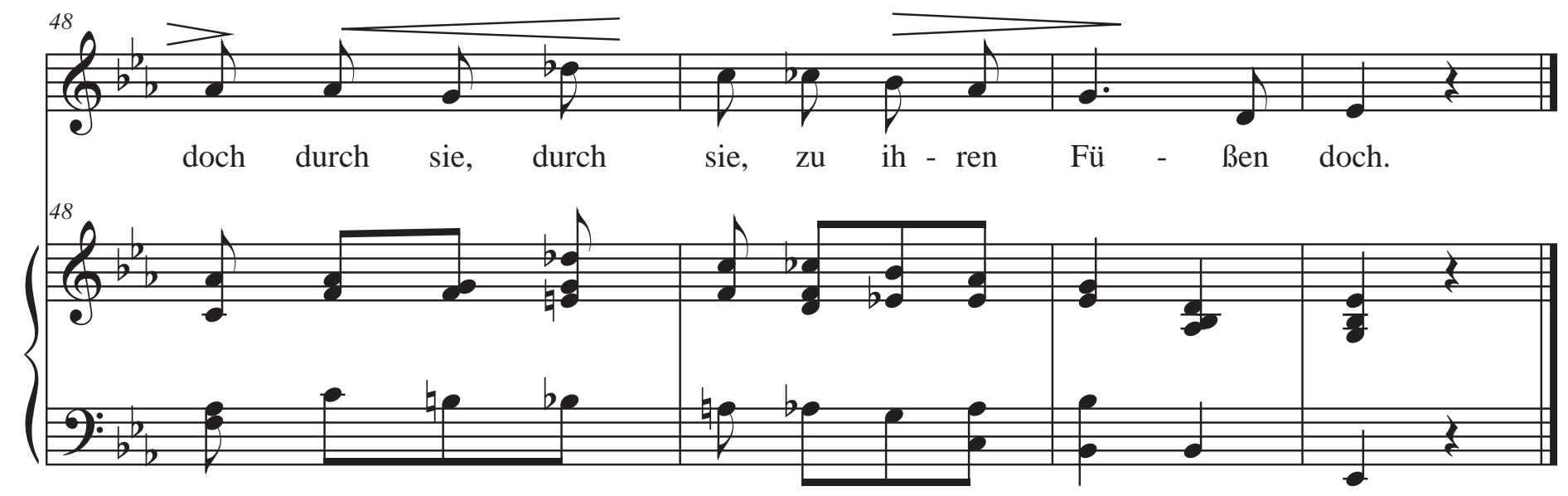